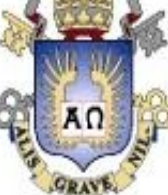

Flavia Lobo de Castro Antunes

A construção de conteúdo para programação educativa em TV: desafios em comunicação e educação

Dissertação de Mestrado

Dissertação apresentada como requisito parcial para obtenção do grau de Mestre pelo Programa de Pósgraduação em Educação do Departamento de Educação do Centro de Teologia e Ciências Humanas da PUC-Rio..

Orientadora: Prof ${ }^{a}$. Magda Pischetola 


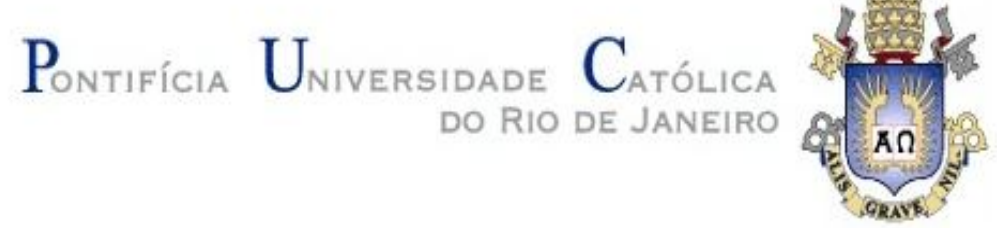

Flavia Lobo de Castro Antunes

\title{
A construção de conteúdo para programação educativa em TV: desafios em comunicação e educação
}

Dissertação apresentada como requisito parcial para obtenção do grau de Mestre pelo Programa de Pósgraduação em Educação do Departamento de Educação do Centro de Teologia e Ciências Humanas da PUC-Rio. Aprovada pela Comissão Examinadora abaixo assinada.

\author{
Prof ${ }^{a}$. Magda Pischetola \\ Orientador \\ Departamento de Educação - PUC-Rio \\ Profa Patrícia Coelho da Costa \\ Departamento de Educação - PUC-Rio
}

Prof ${ }^{a}$ Ana Baumworcel

UFF

Prof. Denise Berruezo Portinari

Coordenadora Setorial do Centro de

Teologia e Ciências Humanas

Rio de Janeiro, 13 de abril de 2015. 
Todos os direitos reservados. É proibida a reprodução total ou parcial do trabalho sem autorização do autor, do orientador e da universidade.

Flavia Lobo de Castro Antunes

É graduada em Comunicação Social, habilitação Jornalismo, pela UFF, 1998. É pós-graduada, lato sensu, em Comunicação e Imagem, pela PUC-Rio, 2006. Possui experiência em jornalismo, com ênfase em TV. É repórter e apresentadora de TV, na MultiRio, desde 2006.

Ficha Catalográfica

Antunes, Flavia Lobo de Castro

A construção de conteúdo para programação educativa em TV : desafios em comunicação e educação

/ Flavia Lobo de Castro Antunes ; orientador: Magda Pischetola. -2015.

$131 \mathrm{f.}:$ il. ; $30 \mathrm{~cm}$

Dissertação (mestrado)-Pontifícia Universidade

Católica do Rio de Janeiro, Departamento de Educação, 2015.

Inclui bibliografia.

1. Educação - Teses. 2. TV educativa. 3. Programação educativa. 4. Broadcasting educativo. 5. Televisão e educação. I. Pischetola, Magda. II. Pontifícia Universidade Católica do Rio de Janeiro. Departamento de Educação. III. Título.

CDD: 370 
À minha mãe, professora e minha primeira mestra, que me mostrou que ensinar pode ser um encantamento através de múltiplos meios. Aos meus colegas de MultiRio pelo esforço diário em produzir mídia educativa de qualidade. E aos meus entrevistados, que ao longo desses anos me fizeram - e fazem - desejar, a cada dia, uma educação pública respeitável e um país melhor. Obrigada! 


\section{Agradecimento}

A Deus, que me fortaleceu durante todo o percurso com sua Palavra: “ [...] quando atravessar águas profundas, eu estarei ao seu lado”, Isaías 43-2.

À minha mestra, orientadora e amiga, Magda Pischetola, pela confiança, conhecimento e por dividir comigo esta jornada.

Aos professores do Programa de Pós-Graduação em Educação da PUC-Rio, que contribuíram abundantemente com seus saberes para este projeto.

E à PUC-Rio, pela acolhida nesta universidade que tanto admiro e concessão de bolsa VRAC, garantindo a isenção total da mensalidade. 


\section{Resumo}

Antunes, Flavia Lobo de Castro. Pischetola, Magda. A construção de conteúdo para programação educativa em TV: desafios em comunicação e educação. Rio de Janeiro, 2015. 131p. Dissertação de Mestrado Departamento de Educação, Pontifícia Universidade Católica do Rio de Janeiro.

A dissertação trata das questões enfrentadas por profissionais de comunicação e educação, que trabalham na produção de conteúdo para TV educativa. O estudo de caso, desenvolvido com 10 produtores da MultiRio, no período de maio a julho de 2014, seguiu a abordagem qualitativa. O foco da análise é a percepção de conteúdo educativo compreendida por estes profissionais e como esta acepção norteia a produção destes programas. A TV educativa, lócus desta pesquisa, apresenta características comuns ao meio, como entretenimento e informação. Todavia, possuiu peculiaridades, constituindo o objetivo primeiro deste tipo de emissora: educar e formar a audiência. $\mathrm{O}$ presente trabalho desenvolve-se a partir da Pedagogia da Comunicação, desenvolvida por Mario Kaplún, no estudo da educação e da comunicação, configurando o que o autor chamou de educação informal, assumindo esta modalidade de TV seu papel na promoção do desenvolvimento humano. A MultiRio é a empresa municipal de multimeios, vinculada à Secretaria Municipal de Educação do Rio de Janeiro. Os objetivos da empresa são a articulação entre a sociedade e a educação, atuando ainda na capacitação continuada de professores e alunos da rede pública municipal. Desde sua criação, em 1993, foram mais de 4.200 programas produzidos e veiculados em sistema aberto e fechado de televisão. As considerações do estudo demonstram a existência de conflito entre as duas áreas, evidenciando uma tensão entre aprendizagem e entretenimento, sugerindo que este conflito pode ter origem na percepção sobre o papel da escola e do ensino na sociedade e desta através da TV.

\section{Palavras-chave}

TV educativa; Programação educativa; Broadcasting educativo; Televisão e educação. 


\section{Abstract}

Antunes, Flavia Lobo de Castro. Pischetola, Magda (Advisor).Building content for educational TV programs: communication and education challenges. Rio de Janeiro, 2015. 131p. MSc. Dissertation- Departamento de Educação, Pontifícia Universidade Católica do Rio de Janeiro.

This dissertation brings questions which are faced by communication and education professionals who work with content production for educational TV. This is a case study that has a qualitative approach. It was developed from May to July of 2014 with ten producers who work at MultiRio. The focus of this analysis is to perceive how these professionals comprehend educational content and also to understand how this perception influences the production of these programs. Educational TV has its own characteristics such as entertainment and information. However, it has its peculiarities. The first goal of this kind of station is educating and achieving viewership. This research was developed within the studies of Mario Kaplún on Pedagogy of communication. This author brought the concept of informal education assuming that this type of TV plays a role in promoting human development. MultiRio is a city government company which is connected to the Educational Secretary of the city. The company goals are mainly to articulate society and education as well as promoting continued formation for students and teachers from public schools. Since its creation, the company has produced and aired more than 4.200 programs both on open and paid TV. This study found out that there is a conflict between the two fields which showed a tension between learning and entertaining. It suggests that this conflict may have been originated in the perception about the role of the school and the role of teaching in the society and through TV.

\section{Keywords}

Educational TV; Educational Programs; Educational Broadcasting; Television and Education. 


\section{Sumário}

1.Introdução 12

2.Atenção, no ar! 19

2.1. A linguagem da televisão 28

2.2. Grade de Programação, Gêneros e Formatos 32

3.TV Educativa: escola na TV? 36

3.1. Construindo a TV Educativa 36

3.1.1. A complexa definição de TV Educativa 40

3.1.2.O papel cultural da TV Educativa 44

3.1.3. O alto custo da penúria na TV Educativa 45

3.1.4. Motivação e audiência: nem sempre parceria de sucesso 47

3.1.5.Educação e cultura na TV atual $\quad 50$

3.2. "Uma pedagogia para a comunicação" 54

3.3. Abrindo a grande angular: o levantamento bibliográfico 58

4. MultiRio, um estudo de caso 62

4.1. Justificativa $\quad 65$

4.2. Metodologia 66

$\begin{array}{ll}\text { 4.2.1. Instrumentos de Pesquisa } & 73\end{array}$

5. Resultados e reflexões $\quad 79$

5.1. Perfil da Amostra $\quad 79$

5.2. O que é um programa educativo 81

5.3. Gêneros de programas educativos 85

5.4. Portaria interministerial $\mathrm{n}=651$, de 1999

5.5. Como surge um programa? 90

5.6. Como é a relação entre educadores e comunicadores? 92

5.7. Conteúdo educativo em TV é entretenimento? 95

5.8. Os professores encaram a TV como espaço educador? 100

5.9. Quem é o público da TV Educativa? 101

5.10. Hipóteses para a baixa audiência 104

5.11. O programa educa? 110

5.12. Qual o futuro da TV Educativa? 112

6. Discussões e conclusão 114

6.1. Produção subjetiva hierarquizada e pouco colaborativa 115

6.2. Audiencia desconhecida e (portanto) inalcançada 117

6.3. O conceito de cultura como apropriação social 118

6.4. Visões diferentes da TV Educativa, entre forma e conteúdo 119

6.5. Fazer TV com recursos limitados 121

7. Referências bibliográficas 124

8. Anexo: Grades Curriculares faculdades de Educação e 130

Comunicação 


\section{Lista de Tabelas}

Tabela 1 - Produção Núcleo de TV, 2014 


\section{Lista de Figuras}

Figura 1 - Gêneros educativos 86

Figura 2 - Categorias de programas educativos conforme 87 portaria $\mathrm{n} \div 651$

Figura 3 - Segmentos que compõe a audiência

101

Figura 4 - Motivos apresentados para a baixa audiência

106

Figura 5 - Hipóteses para o sucesso de Vila Sézamo, Sítio do Pica Pau Amarelo e Castelo Rá Tim Bum 


\section{Lista de Abreviaturas e Siglas}

Anped - Associação Nacional de pós-graduação e pesquisa em educação.

BAND - TV Bandeirantes.

BBC - British Broadcasting Corporation.

BDTD - Biblioteca Digital Brasileira de Teses e Dissertações.

CTT - Comissão Técnica de Televisão.

CNBB - Conferência Nacional dos Bispos do Brasil.

FCBTVE - Fundação Centro Brasileiro de Televisão.

IBCT - Instituto Brasileiro de Informação em Ciência e Tecnologia.

IBGE - Instituto Brasileiro de Geografia e Estatística.

IBOPE - Instituto Brasileiro de Opinião Pública e Estatística.

Intercom - Sociedade Brasileira de Estudos Interdisciplinares da Comunicação.

MC - Ministério das Comunicações.

MEB - Movimento de Educação de Base.

MEC - Ministério da Educação.

MultiRio - Empresa Municipal de Multimeios.

NET - TV por assinatura.

RCA - Radio corporation of America.

TVE - Televisão Educativa.

SNJ - Secretaria Nacional de Juventude

Unesco - Organização das Nações Unidas para a Educação, a Ciência e a Cultura 


\section{1.}

\section{Introdução}

“- Atenção professor, nós vamos gravar. Preciso que você dê sua aula normalmente, como se não estivéssemos aqui. E lembre-se: o que vale para mim é o processo pedagógico, o passo a passo da sua aula. Ok. 3, 2, 1, gravando!"

Com esta fala, iniciei inúmeras gravações em escolas da rede pública municipal de ensino do Rio de Janeiro. As matérias exibidas pela MultiRio têm o objetivo de levar às escolas e domicílios da cidade o dia a dia da comunidade escolar. Uma escola bem sucedida; um aluno ou professor com seus projetos curiosos; um novo conceito ou descoberta científica ou social que pode transformar a rotina da sociedade e da escola, provocando uma discussão a respeito.

A mim, cabe apurar, observar, questionar, entrevistar, esclarecer e colocar tudo isto em ordem, num texto feito de imagem e som. Ir além de entender a escola como notícia, fazendo da televisão aprendizagem.

Este é o panorama visto sob a perspectiva de uma lente grande angular, captando a imagem como um todo. No entanto, optei por olhar o set por uma lente macro e me aproximar ao máximo dos bastidores de uma programação educativa em TV. Já não mais como repórter somente, mas sob a ótica da pesquisa em educação.

Duarte (2004), ao analisar a textualidade da TV, afirma que o próprio modelo de funcionamento da televisão acaba por definir seus modos de enunciação. A produção é coletiva e, consequentemente, os sujeitos do discurso também são plurais, mesmo que o enunciado esteja tão alinhado, que pareça ser único e pessoal. Em decorrência do tipo de mediação empregada, os enunciadores do processo de comunicação televisiva nunca estão presentes. Tanto produtores quanto audiência são invisíveis, embora não inexistentes.

Justamente por estar neste lugar híbrido - ainda que duplamente invisível de produção e audiência, percebi a importância de estudar os sujeitos produtores de programação educativa em televisão. A movimentação por trás das câmeras, as escolhas pelos enquadramentos, as pautas, o enfoque dado aos conteúdos, enfim, 
todo um esforço realizado para que o programa A ou B vá ao ar com a finalidade de educar. Nasci na década de 70, e desde pequena me interesso por televisão. $\mathrm{Na}$ época, a oferta de canais no Brasil era reduzida, contando apenas com emissoras de transmissão aberta e gratuita. Pela TV, entrei em contato com o universo mágico de Monteiro Lobato, cujo Sítio do Pica-pau Amarelo inspirou muitas das minhas aventuras infantis. Descobri a poesia de Vinícius de Moraes, cantada por Chico Buarque, Ney Matogrosso e outros nomes da música popular brasileira, através do especial A Arca de Noé, dirigida por Augusto César Vannucci. E pela extinta TVE, assisti à Turma do Lambe Lambe, de Daniel Azulay, desenvolvendo o gosto pelo desenho, entre tantos programas que me divertiram e me ensinaram muitas coisas. Para mim, televisão era lugar de aprender brincando!

Em 1998, formei-me em jornalismo, iniciando minha trajetória profissional em televisão. Percurso percorrido até hoje. Exerci as atividades de apuração, produção, edição e reportagem na TV Bandeirantes do Rio de Janeiro e na TV Canção Nova, entre os anos de 1998 e 2005. Em 2006, ingressei na MultiRio e, de lá pra cá, troquei as reportagens sobre política, esportes e dia a dia pelas questões da escola e sociedade.

Pude notar que a prática jornalística da área educativa difere do que se convenciona jornalismo factual (o jornalismo que é feito diariamente pela grande imprensa). Em hard news ou factual, a notícia é o fato em si, o que aconteceu e sua consequência. Já no jornalismo educativo privilegia-se a abordagem profunda, contextualizada dos fatos, denominada feature, incluindo a compreensão do processo pedagógico. O tempo de contar a história é diferente. Não só em minutos de exibição, mas na linguagem, pois o "como" ensinar e aprender torna-se preponderante. Desta forma, os produtores de conteúdo transferem a didática ao que vai ser transmitido no ar. Libâneo ${ }^{1}$ (2002) explica que o processo didático é o conjunto de atividades do professor e alunos, sob o comando do professor, cujo objetivo é a assimilação dos conhecimentos pelos alunos, o desenvolvimento de habilidades intelectuais, hábitos, atitudes e capacidades. No caso do conteúdo educativo para televisão o objetivo claro é educar, de modo formal ou informal,

\footnotetext{
${ }^{1}$ José Carlos Libâneo - Filósofo. Doutor em Filosofia e História da Educação pela Pontifícia Universidade Católica de São Paulo. Professor titular do programa de pós-graduação da Universidade Católica de Goiás, cuja linha de pesquisa engloba Teorias da Educação e Processos Pedagógicos. Pesquisa e escreve sobre teoria da educação, didática, formação de professores, ensino e aprendizagem, organização e gestão da escola. Atualmente desenvolve pesquisas dentro da teoria histórico-cultural, com ênfase na aprendizagem, ensino e organização da escola.
} 
objetivando a aquisição de conhecimento. $\mathrm{O}$ autor esclarece que as mídias desempenham três funções pedagógicas: mediação de ensino; competência tecnológica e meios físicos da comunicação humana. Para ele, os meios tecnológicos de comunicação humana (visuais, cênicos, verbais, sonoros, audiovisuais) dirigidos para o ensinar a pensar, ensinar a aprender a aprender implicam efeitos didáticos como autonomia, estratégias cognitivas, facilidade de análise e resolução de problemas, etc. Kaplún² (1998) também entende que o processo de ensino e aprendizagem, o "como" deve ser privilegiado na educação feita por meio da radiodifusão, entendida num sentido mais amplo, procurando a transmissão de valores, a promoção humana, desenvolvimento integral da sociedade, estimulando o pensamento crítico. Sendo assim, a produção de conteúdo educativo e o próprio conteúdo educativo veiculado acabam por reproduzir o modelo didático aplicado na sala de aula tradicional.

Ao propor pesquisar os produtores de conteúdo educativo em TV, busquei a nitidez em teóricos como Pierre Bourdieu ${ }^{3}$, Jesús Martín-Barbero ${ }^{4}$, Marshall McLuhan ${ }^{5}$, Harold Lasswell ${ }^{6}$; o pensamento do teórico em educação Mario

\footnotetext{
${ }^{2}$ Mario Kaplún - Radialista, educomunicador e escritor. Estudou os processos de comunicação e educação através da radiodifusão, promovendo o conceito de comunicação transformadora em oposição à comunicação bancária. Sua análise recai sobre o papel atuante do educomicador, termo cunhado por ele, para designar o sujeito educador e comunicador atuante em atividades sociais, jornalismo comunitário, imprensa alternativa e comunidades periféricas.

${ }^{3}$ Pierre Bourdieu - Filósofo, professor, antropólogo e sociólogo francês. Sua produção estende-se pelos campos da Sociologia, da Educação e da Comunicação. É crítico dos mecanismos de reprodução das desigualdades sociais, pesquisando sobre as relações que se estabelecem entre o universo da cultura e o campo do poder e das classes sociais. Bourdieu constitui-se importante referencial no campo das ciências humanas. Entre suas principais publicações estão La reproduction (1970), onde apresenta a noção de violência simbólica; La distinction (1979), centrada na perspectiva sociológica de uma teoria dos gostos e estilos de vida; La misere du Monde (1993), coletânea organizada por Bourdieu que debruça-se sobre os males do campo, dos trabalhadores, empregados, camponeses, da família, da cidade, da escola e da fábrica, expressando a miséria do mundo contemporâneo.

${ }^{4}$ Jesús Martín-Barbero - Semiólogo, antropólogo e filósofo. Teórico da Comunicação e Cultura nos Estudos Culturais contemporâneos. É autor do livro Dos Meios às Mediações (2009). Sua contribuição é significativa quanto aos Estudos de Recepção, das mediações culturais e da valorização das culturas latino-americanas.

${ }^{5}$ Marshall McLuhan — Teórico da Comunicação. Filósofo e professor canadense, sua pesquisa se debruça sobre os meios de comunicação e a relação destes com a cultura e sociedade ocidental. Entre suas principais publicações estão A Galáxia de Gutenberg (1962), onde analisa os efeitos da mídia de massa, especialmente a impressa, na sociedade; Understanding Media, (1964) centrada nos efeitos da mídia na sociedade e cultura, definindo os meios de comunicação como extensões tecnológicas do corpo; O Meio é a Mensagem (1967) onde teoriza sobre o efeito sensório que cada meio tem no ser humano.

${ }^{6}$ Harold Dwight Lasswell - Pesquisador da Universidade de Chicago, cientista político e teórico da Comunicação. É considerado um dos principais nomes da corrente norte-americana Mass Communication Research, investigando os efeitos da mensagem das propagandas alemãs, francesas, britânicas e americanas durante a Primeira Grande Guerra. Seus estudos sobre
} 
Kaplún; as contribuições de especialistas no setor, como Agustín García Matilla ${ }^{7}$, Rosa Maria Bueno Fischer ${ }^{8}$, Harris Watts ${ }^{9}$, Elizabeth Bastos Duarte ${ }^{10}$, Mônica Cristine Fort $^{11}$.

A abordagem inicial deste estudo foi construída a partir da Pedagogia da Comunicação, desenvolvida por Kaplún (1998), cuja teoria reside em desenvolver uma educação para a comunicação. Uma pedagogia, ou seja, um conjunto de teoria e práticas que permitem refletir, questionar, compreender a comunicação enquanto ato educativo, resultando numa comunicação educativa efetiva capaz de originar um processo educativo transformador, suscitando a reflexão, o pensamento crítico de emissores e receptores. Este resultado é o que Kaplún vai designar como uma bem-sucedida comunicação educativa, e na verdade, vai trabalhar com este conceito, referindo-se a este como comunicação educativa. Segundo o autor, os produtores de comunicação em educação devem destacar a importância do processo de transformação da pessoa e das comunidades, não se preocupando tanto com os conteúdos que vão ser comunicados e nem com os efeitos do comportamento ao fim da comunicação. O olhar deve centrar na

psicologia e política e sobre a relação entre as mídias e a sociedade foram fundamentais para que desenvolvesse o modelo de comunicação que, segundo Lasswell, resultaria na correta, clara e completa compreensão da mensagem midiática: "Quem? Diz o quê? Através de que canal? A quem? Com que efeito?".

${ }^{7}$ Augustín García Matilla - Doutor em Ciências da Informação pela Universidad Complutense de Madrid. Professor de Teoria e Técnica de Informação Audiovisual da mesma universidade. Pesquisa a influência da televisão no ambiente familiar e escolar. Foi diretor da Telemadrid, TV pública de Madrid. É autor ou co-autor de vários livros sobre pedagogia da mídia como Una television para la educacion: la utopia posible (2003) e Lectura de imagenes en la era digital (2008).

${ }^{8}$ Rosa Maria Bueno Fischer - Doutora em Educação pela Universidade Federal do Rio Grande do Sul (1996). Tem experiência na área de Educação e da Comunicação, com ênfase em Sociologia e Filosofia da Cultura, estudos foucaultianos e pesquisas sobre mídia, juventude e processos de subjetivação.

${ }^{9}$ Harris Watts - Produtor, roteirista e diretor de TV da BBC TV Training Production for the Education \& Training Division of BBC Enterprises.

${ }^{10}$ Elizabeth Bastos Duarte - Professora e pesquisadora do Programa de Pós-Graduação em Ciências da Comunicação da Unisinos. Pós-doutora em Televisão pela École des Hautes Études en Sciences Sociales (França) e pela Université de Paris III Sorbonne Nouvelle (França). Especialistas em estudos midiáticos, em especial, Televisão, atuando na intersecção entre semiótica e teorias da comunicação.

11 Mônica Cristine Fort - Professora do Programa de Pós-Graduação em Comunicação e Linguagens da Universidade Tuiuti do Paraná. Graduada em Comunicação Social Jornalismo pela Universidade Federal do Paraná (1988), mestre em Educação pela Pontifícia Universidade Católica do Paraná (1999) e doutora em Engenharia de Produção pela Universidade Federal de Santa Catarina (2004), com pesquisa em Mídia e Conhecimento. Tem experiência na área de Comunicação, com ênfase em videodifusão, atuando principalmente nos seguintes temas: jornalismo, televisão, educação, comunicação empresarial e comunicação audiovisual. 
interação dialética entre as pessoas e suas realidades, permitindo a tomada de consciência social e o desenvolvimento de suas capacidades intelectuais.

Em análise crítica, Kaplún (1999) observa que a radiodifusão educativa é quase sempre "seca, chata e aborrecida" como ele diz, e que tem sido feita num tom escolar, no que Paulo Freire (1987) classificou como educação bancária, onde o emissor/professor deposita seus conteúdos no receptor/aluno, reproduzindo a tradicional escola primária clássica. O mesmo ocorre, segundo o autor, com a noção de "espaço cultural" geralmente compreendida como o oposto de "popular", tornando assim distante das grandes massas os programas considerados eruditos, educativos.

Kaplún chama a atenção, também, para o fato de que o entretenimento característico do meio TV não deve ser tomado como algo banal e vazio, mas sim frutífero e educativo. A programação educativa pode e deve alcançar, atrair e servir à população.

Ainda na busca pelos referenciais bibliográficos, encontrei um verdadeiro baú do tesouro para a discussão sobre televisão educativa: uma coletânea com artigos e depoimentos dos principais broadcasters dos Estados Unidos e teóricos da Mass Communication Research, num amplo debate sobre a produção educativa em TV, datado da década de 60, porém extremamente atual. A contribuição das joias ali encontradas foi fundamental para as considerações deste estudo.

Ao entender a comunicação pelo viés da educação, a televisão se torna um campo fértil para reflexões, considerando suas características e possibilidades plurais para além das críticas, possibilitando novas formas de fazer e aprender.

E foi esta ânsia em aprender e a curiosidade própria do jornalista que me levaram ao mestrado em Educação, da PUC Rio, onde encontrei profissionais e pesquisadores voltados às questões relativas aos processos culturais midiáticos e a educação. A troca cultural, as experiências ricas de conhecimento de professores e pesquisadores deste programa me proporcionaram não apenas olhar o set, como eu disse, sob outra ótica. Mas enxergar o cenário pela visão transformadora da educação. Sinto-me como a mulher do poema de Rubem Alves, que disse estar ficando louca ao psicanalista, ao perceber, pela primeira vez, os legumes que cozinhava todos os dias. 
... cortada a cebola, eu olhei para ela e tive um susto. Percebi que nunca havia visto uma cebola. Aqueles anéis perfeitamente ajustados, a luz se refletindo neles: tive a impressão de estar vendo a rosácea de um vitral de catedral gótica. De repente, a cebola, de objeto a ser comido, se transformou em obra de arte para ser vista! E o pior é que o mesmo aconteceu quando cortei os tomates, os pimentões... Agora, tudo o que vejo me causa espanto. [...] me levantei, fui à estante de livros e de lá retirei as Odes Elementales, de Pablo Neruda. Procurei a Ode à Cebola e lhe disse: Essa perturbação ocular que a acometeu é comum entre os poetas. Veja o que Neruda disse de uma cebola igual àquela que lhe causou assombro: Rosa de água com escamas de cristal. Não, você não está louca. Você ganhou olhos de poeta... Os poetas ensinam a ver. (ALVES, 2004)

Rubem Alves, poeta, filósofo e educador, afirmou que a primeira função da educação é ensinar a ver. E foi assim, aprendendo a ver pela lente da educação, que voltei os meus olhos ao cotidiano da produção em televisão educativa. In loco.

Para melhor compreensão desta dissertação, o estudo foi organizado em seis capítulos, apresentando os principais aspectos:

O primeiro capítulo, Atenção, no ar!, apresenta o desenvolvimento da Televisão no cenário internacional e o impacto que a chegada do meio causou na radiodifusão brasileira. Nesse momento, é fundamental compreender como a linguagem da TV evoluiu a partir do rádio e o desenho traçado pela televisão nos primeiros passos em direção a sua própria linguagem. O subcapítulo Linguagem da televisão apresenta o sistema de códigos e características que compõem a linguagem e a textualidade da televisão.

No segundo capítulo, TV educativa: escola na TV?, a discussão é em torno do que é a TV educativa, qual o seu objetivo, a diferença entre esta e as emissoras comerciais, a questão do financiamento público, a relação com a audiência, o papel dos comunicadores educativos. Esse papel é aprofundado no subcapítulo "Uma pedagogia para a comunicação", reunindo os conceitos que levaram Mário Kaplún a desenvolver uma pedagogia para a comunicação com finalidade de desempenhar, plenamente, uma comunicação educativa. Aqui, o levantamento bibliográfico revela quais os caminhos percorridos pelo campo, evidenciando a necessidade de pesquisas sobre o tema.

O terceiro capítulo, MultiRio, um estudo de caso, apresenta a empresa, justificando sua importância para o setor e sua contribuição para a discussão acadêmica em torno do produção de conteúdo educativo em TV. O subcapítulo 
Metologia expõe a organização e instrumentos utilizados para esta pesquisa e como este estudo foi construído adotando a abordagem qualitativa.

Em Resultados e reflexões, quarto capítulo, é possível constatar os dados que emergiram da pesquisa de campo, relacionando a percepção que os produtores da MultiRio têm sobre conteúdo educativo em TV à prática da construção de uma programação educativa, propondo uma discussão e análise a partir dos pressupostos de Mário Kaplún.

Por último, em Discussões e Conclusão são apresentadas as principais conclusões desenvolvidas no estudo e expostas algumas considerações relevantes, sugerindo investigações futuras. 


\section{2. Atenção, no ar!}

Os primeiros estudos para transmissão de imagens ocorreram no século XIX, na Europa. Os químicos sueco Jöns Jakob Berzellus, em 1817, e o alemão Willougeby Smith May, em 1873, observaram a propriedade de foto condução do selênio ao ser exposto à luz. A descoberta foi fundamental para pesquisas posteriores de transmissão de imagens. Em 1884, o engenheiro elétrico alemão, Paul Gottlieb Nipkow, patenteou o que se tornaria a primeira teoria eletroquímica de transmissão de TV. Ele constatou que o selênio, além de conduzir energia elétrica, transformava a eletricidade. Nipkow ampliou esta condutividade para capturar imagens, discernindo entre luz e sombras. As experiências não cessaram e em 1924, no sul da Inglaterra, o engenheiro elétrico escocês, John Logie Baird, conseguiu transmitir uma imagem por uns poucos metros. Dois anos depois, Baird aperfeiçoaria a técnica. Diante de uma plateia de 50 cientistas, ele mostraria ao mundo a primeira transmissão de imagens à longa distância. Em 1926, convicto de que estava no caminho certo, Baird conseguiria a façanha de transmitir, a bordo de um navio no meio do Atlântico, imagens entre Londres e Nova York.

Os experimentos avançaram rápida e notavelmente na Europa e nos Estados Unidos. Na década de 30, companhias radiofônicas, como a americana Radio Corporation of America (RCA) e a britânica British Broadcasting Corporation (BBC), decidiram investir em television broadcasting. Em 1936, a BBC deixava de transmitir apenas pelo rádio e passava a ser a primeira emissora de TV a veicular regularmente uma programação com dramas, atualidades, esportes e desenhos animados. Nos Estados Unidos, o presidente Franklin Delano Roosevelt seria o primeiro presidente a aparecer na televisão, discursando durante a abertura da Feira Mundial de Nova York, transmitida pela RCA, em 1939. Porém, a televisão mundial sofreria o impacto da Segunda Grande Guerra, com interrupção em investimentos e programação. A popularização da TV só ocorreu de fato ao fim do conflito.

No Brasil, a televisão chegou em 1950, com o entusiasmo de Assis Chateaubriand, fundador e proprietário dos Diários Associados. O jornalista, advogado e empresário criou as Emissoras Associadas e colocou no ar a primeira 
estação de televisão brasileira, a PRF-3 Tupi Difusora, de São Paulo. Vida Alves ${ }^{12}$ (2008), redatora pioneira e responsável pelos registros e depoimentos que preservaram boa parte memória da televisão brasileira, narra o frenesi que a nova tecnologia causou em Chateaubriand, durante visita à RCA, em 1944. Na época, Chateaubriand já era pioneiro no uso de rádio na América do Sul. Recepcionado pelo presidente da Radiodifusora America, David Sarnoff, Chateaubriand decidiu fazer uma revolução nas comunicações brasileiras.

- O que é isso?

- Uma câmera de televisão. Imagem eletrônica. E esse é o senhor Wladimir Zworykin, um russo-americano, o inventor. Sua invenção é tão importante que o colocamos na vice-presidência da RCA Victor. Com essa lente podemos ver toda Manhattan.

- Imagem a distância... Pois eu vou querer uma emissora.

- Senhor Chateaubriand, isto não é para um país como o Brasil. O senhor deveria se preocupar com sua poderosa rede radiofônica. A televisão não é recomendável para os brasileiros. O senhor deveria esperar...

- Esperar o quê? E lhe digo mais: não quero uma emissora. Quero duas. A primeira, criarei em São Paulo e a segunda, no Rio de Janeiro. Se eu andar depressa, a de São Paulo será a primeira da América Latina. Seremos pioneiros. A primeira será em São Paulo... Por favor, anote meu pedido. (ALVES, 2008, p. 2425)

De fato, o Brasil foi um dos cinco primeiros países do mundo e o primeiro da América Latina a ter televisão. Para garantir a audiência, Chateaubriand importou e distribuiu duzentos aparelhos receptores pela cidade para que o público pudesse acompanhar as primeiras exibições. Os televisores foram espalhados em locais de São Paulo, como Jockey Clube, Lojas Mappin e o saguão dos Diários Associados. E mesmo com uma das câmeras importadas pela RCA quebrada momentos antes da transmissão inaugural, a PRF-3 Tupi Difusora de São Paulo entrou no ar graças ao esforço do radialista Cassiano Gabus Mendes. Segundo Federico ${ }^{13}$ (1982), pela TV foram exibidas imagens de pessoas ouvindo rádio, seguindo da apresentação das opções de uma pretensa programação. $\mathrm{O}$ público pode acompanhar em sequência um número musical de orquestra; um

\footnotetext{
${ }^{12}$ Vida Alves - Atriz, autora, produtora, redatora, garota-propaganda e apresentadora de TV. Com experiente carreira no rádio desde 1940, Vida Alves foi pioneira na Televisão Brasileira, participando da primeira transmissão do país, na TV Tupi. Anos mais tarde, fundou a Associação dos Pioneiros da Televisão Brasileira, que depois passou a ser chamada de PRÓ-TV. Vida Alves também criou o Museu da TV.

${ }^{13}$ Maria Elvira Bonavita Federico - Professora graduada em Radio e Televisão pela Universidade de São Paulo (1971), graduação em Desenho e Plástica Licenciatura Plena pela Fundação Armando Álvares Penteado (1971). Mestre em Ciências da Comunicação pela Universidade de São Paulo (1976) e doutorado em Arquitetura e Urbanismo pela Universidade de São Paulo (1997).
} 
sketch de Escolinha do Ciccilo; uma cena de humor com Mazzaropi numa fazenda; uma chamada romântica para a novela Pé de Manacá; uma maquete de um estádio com o apresentador Aurélio Campos discursando sobre as maravilhas de se acompanhar o futebol pela TV. A transmissão durou 1h50. O fato marcou não apenas a história da televisão nacional. Mas também, a trajetória dos profissionais de radiodifusão do país. Alves descreveu como a emoção tomou conta dos bastidores naquele dia:

Ganhamos um brinquedo e começamos a brincar. Essa frase de Cassiano Gabus Mendes diz tudo. Experiência, curiosidade, aventura, ansiedade, erro, acerto, medo, alegria, choro, sangue, tudo, tudo aquilo que o homem tem em sua natureza pura, em sua essência, em seu cerne, em seu coração. Vida latente, nascente. Criação. Nascimento. (ALVES, 2008, p.17)

E qual seria o conteúdo da televisão brasileira em suas primeiras transmissões? Alves (2008) conta que na mesma noite de inauguração, Cassiano Gabus Mendes ordenou que todos os seus auxiliares diretos percorressem os consulados de São Paulo em busca de filmes, como os do teórico Marshall McLuhan. O fato registra o improviso da televisão brasileira nos primórdios de sua realização.

A programação da TV Tupi começava às 20 horas e terminava às 23 horas. Nestas três horas, eram exibidas notícias com o telejornal Imagens do Dia; quadros de humor como Rancho Alegre; crônicas românticas em Romance; apresentação de orquestras, música regional e balé; números de circo com os palhaços Arrelia, Fuzarca e Torresmo; folclore; luta livre com Hércules e seus lutadores e até aulas de inglês com o professor Fisk como professor-apresentador. Um ano depois, fruto do desejo de Chateaubriand e da experiência em São Paulo, entrava no ar outra estação das Emissoras Associadas: a TV Tupi canal 6 do Rio de Janeiro. Para manter a emissora no ar, foi preciso recrutar profissionais experientes do rádio, cujo nome técnico profissional — radialistas — é mantido até hoje para aqueles que trabalham em televisão.

A televisão incorporou do rádio não apenas os programas, mas a linguagem radiofônica caracterizada pelo texto falado e feito para ser ouvido, valendo-se dos elementos sonoros da linguagem radiofônica como músicas, canções, sonoplastia, a fala e o silêncio. No rádio, a linguagem é clara, simples e objetiva, recorrendo a 
palavras familiares aos ouvintes, num texto coloquial, como explica Porchat ${ }^{14}$ (2004, p. 97) "contar apenas com a audição significa que o som deverá suprir a falta da imagem. Isso demanda uma linguagem mais do que clara, uma linguagem nítida, para que o ouvinte veja através das palavras" (itálico nosso). O texto no rádio tem o poder de evocar imagens mentais para constituir a história, narrada em detalhes por locutores, que fornecem ao ouvinte informações minuciosas, muitas vezes valendo-se da repetição, para certificar-se de que os dados preciosos foram apreendidos. No rádio, o som produz as imagens auditivas, é ele quem seduz e informa. E o ouvinte, então, a partir do estímulo sonoro, desenvolve suas próprias imagens mentais.

Além da linguagem textual, a televisão absorveu do rádio o híbrido informação-diversão. Dos estúdios radiofônicos vieram os jornais com as notícias de várias partes do planeta, as radionovelas, os musicais, os esquetes humorísticos, os programas de auditório. No Brasil, a Rádio Nacional foi alavanca para a programação da TV no país. Do edifício A Noite migraram produtores, diretores, redatores, apresentadores, atores e atrizes para as emissoras de TV do Rio de Janeiro e de São Paulo. Em 1964, por exemplo, a radionovela O Direito de Nascer foi exibida pela TV Tupi, mesma emissora para onde iria o radiojornal $\mathrm{O}$ Repórter Esso quatro anos mais tarde.

Todavia, os improvisos começaram a ser substituídos por uma gramática própria a partir de 1955, percebendo que a força motriz da televisão é a imagem. E uma imagem íntima, recebida dentro de casa. Ainda que os primeiros passos tenham sido levados pelas seguras mãos do rádio, a televisão não demorou a se pôr de pé e consagrar-se como o mais influente veículo de massa da segunda metade do século XX.

Ninguém suspeitava sequer como chegar a uma linguagem televisiva. O caminho galgado pelo rádio fora árduo, porém o específico televisivo era outro e o pessoal era o mesmo. Partiu-se para uma experimentação curiosa, incompatível com a estrutura comercial. [...] Apesar de tudo, sem ter tomado o seu rumo, a TV inicial foi pretensiosa, colocando no ar nada menos que adaptações de Shakespeare, como Hamlet e MacBeth, e Dostoievski, Crime e Castigo, e outros clássicos. (FEDERICO,1982, p.84)

\footnotetext{
${ }^{14}$ Maria Elisa Porchat - Jornalista e professora de Língua Portuguesa. Trabalhou nas rádios Jovem Pan, Trianon e Bandeirantes. Nesta última emissora, exerceu a função de ombudsman na por cinco anos, com programa semanal de crítica jornalística e do português empregado no rádio. Escreveu o primeiro manual de radiojornalismo do país, o da Rádio Jovem Pan, utilizado por profissionais e estudantes da área.
} 
Na década de 60, o país já contava com várias emissoras: TV Record, TVs Tupi RJ e SP, TV Jornal do Comércio, TV Paulista, TV Rio, TV Itacolomi, TV Excelcior, TV Cultura, TV Globo, entre outras. Aliás, é nesta mesma década que surgem as primeiras investidas com emissoras educativas. Federico (1982) observa que foi nesta época que a teleducação começou a ganhar força, quando o então Ministro da Educação, Pedro Aleixo, propôs, em 1966, a unificação da radiodifusão educativa e das emissoras do MEC: rádios Educadora de Brasília, Ministério da Educação no RJ e Sirena em MG. Em São Paulo, a TV Cultura, em parceria com o governo do estado, colocaria no ar o primeiro telecurso destinado aos candidatos ao concurso de admissão ao ginásio ( $5^{\mathrm{a}}$ e $8^{\mathrm{a}}$ séries). No entanto, os investimentos iniciais, avanços técnicos, a experimentação da linguagem televisiva foram, notoriamente, muito mais significativos nas emissoras comerciais, tendo em vista seu desígnio.

É preciso, neste momento do texto, situar brevemente o cenário político e econômico do país, onde todas estas emissoras deram início às suas atividades. Desde Assis Chateaubriand, em 1950, o Brasil vira o general Eurico Gaspar Dutra do Partido Social Democrático (PSD), de bases conservadoras, terminar seu mandato e, novamente, ter à frente da Presidência da República, através de eleições, Getúlio Vargas. No início do governo Vargas, empossado em janeiro de 1951, foram tomadas várias medidas de modo a incentivar o desenvolvimento econômico, sobretudo, com ênfase na industrialização do país. Foram feitos investimentos substanciais no setor de transporte e energia, a fim, inclusive, de levar estes serviços ao interior e a região nordeste do Brasil. E, claro, mesmo estando a maioria das emissoras de televisão na região sudeste, é impossível pensar em TV sem energia e importação de equipamentos, num momento de inflação em alta e flexibilização do dólar em relação à moeda nacional. O período também fora marcado pela tensão entre comunistas e as forças conservadoras, nacionais e internacionais, como os Estados Unidos. Diante do avanço da inflação e das greves dos trabalhadores de diferentes setores insatisfeitos com os altos custos de vida, e da insatisfação militar com as medidas populistas, Getúlio Vargas viria seu governo ruir após do atentado contra seu principal opositor, Carlos Lacerda, no dia 05 de agosto de 1954. O movimento pela renúncia de Getúlio assumiu grandes proporções. E na manhã, do mesmo mês, Getúlio Vargas suicidou-se com um tiro no coração. 
O vice-presidente Café Filho assumiu a presidência garantindo as eleições presidenciais marcadas para outubro de 1955. Nas urnas, ainda sob conturbadas contestações, os resultados deram vitória ao presidente Juscelino Kubitschek e a João Goulart, como vice. Segundo Fausto ${ }^{15}$ (1995), a tensão entre militares e comunistas permanecia e foi preciso que o ministro da Guerra, general Lott, iniciasse o chamado "golpe preventivo", garantindo que o resultado das urnas e a posse do presidente eleito. Os anos de governo de JK foram marcados pelo desenvolvimentista plano de metas, popularmente conhecido como "cinquenta anos em cinco". O programa abrangia 31 objetivos, distribuídos em seis áreas estratégicas: energia, transportes, alimentação, indústrias de base, educação e a construção de Brasília. JK incentivou as importações com fins de desenvolver a indústria nacional, abrindo subsídios à importação de equipamentos, notadamente para estímulo ao setor automobilístico. Mesmo menos conturbado, conforme Fausto (1995), o período do governo de JK é marcado, muito em conta do forte investimento nos mercados industriais, pelo crescimento das forças sindicais. Porém, a calmaria não significava sucesso absoluto. O projeto de governo grandioso concentrou problemas nas áreas de comércio exterior e finanças governamentais. A inflação chegou a patamares elevados, cerca de 40\%, em 1959. Em 1960, após as eleições presidenciais, sucede JK na Presidência da República, Jânio Quadros, criticando a desordem financeira e a corrupção do governo anterior. Jânio ocupou-se de legislar sobre questões moralistas como a proibição, do lança-perfume, do biquíni, da rinha de galos e do conteúdo exibido na TV. Sem apoio político, inflação em alta e dívida externa crescente, Jânio renunciou, em 1961. O período iniciado à sucessão de Jânio Quadros com a posse do vicepresidente João Goulart foi importante para o papel da radiofonia educativa no país.

Nestes meados da década de 1960, o Brasil viu crescer os movimentos sociais agrícolas, como as Ligas Camponesas, formadas por uma população rural proprietária de um pedaço de terra, arrendatários e meeiros, camponeses. À época, também sobressaiu o crescimento da mobilização estudantil, através da União Nacional dos Estudantes, a UNE. A Igreja Católica dividiu suas bases conservadora e progressista, incluindo a Juventude Universitária Católica, de

15 Boris Fausto - Doutor em História e professor no Departamento de Ciência Política da Faculdade de Filosofia, Letras e Ciências Humanas da USP. 
esquerda. E foi com o intuito de alfabetizar a distância a população agrícola através das escolas radiofônicas que fora criado, em 1961, pela Conferencia Nacional dos Bispos do Brasil, o Movimento de Educação de Base, MEB. No setor econômico, o Plano Trienal - que combinava reformas sociais, crescimento econômico e combate a inflação - desagradou moderados, liberais e representantes da esquerda. Os setores ligados aos movimentos sociais ganharam contornos expressivos e o presidente decidiu dar início às reformas de base. A Marcha das Famílias com Deus reuniu, em março de 1964, cerca de 500 mil pessoas em favor de medidas mais conservadoras e sinalizou a insatisfação dos grupos contrários aos comunistas e ao governo. Bases de esquerda dentro da Marinha também irritaram os oficiais das Forças Armadas que reconheceram o período como contrário aos princípios militares nacionalistas como a manutenção da ordem social, o respeito à hierarquia e o combate ao comunismo. Quebrados estes princípios, justificava-se a intervenção militar no governo. O que ocorreu em 31 de março de 1964.

O primeiro presidente militar, o general Humberto de Alencar Castelo Branco, com mandato até 1966, institui o AI-1, que tinha por objetivo aumentar o poder do Executivo e reduzir a ação do Congresso. Instituiu também a repreensão aos movimentos estudantis e no campo e a substituição de partidários de esquerda das funções burocráticas civis. Mandatos foram cassados e suspensos os direitos políticos de opositores. Neste ano de 1964, foi criado o Serviço Nacional de Informações, o SNI, cujo propósito expresso era coletar e analisar informações pertinentes à segurança nacional, à contra-informação e à subversão interna. No campo econômico, redução do déficit governamental, melhora nas contas das empresas públicas e aumento na arrecadação dos impostos produziram inicialmente um impacto no custo de vida. Dois outros Atos Institucionais foram baixados por Castelo Branco fortalecendo os poderes do Executivo. Em 1967, toma posse por eleições indiretas dos representantes políticos do Congresso, o presidente general Artur da Costa e Silva. Neste período, a Igreja Católica, sobretudo no Nordeste, e os estudantes voltaram a se mobilizar contra o governo. Em 1968, as mobilizações ganharam força. E após a morte do estudante Edson Luís, durante um protesto no Rio de Janeiro, eclode a luta armada. Em 13 de dezembro de 1968, Costa e Silva baixa o AI-5, fechando o Congresso. A medida durou até 1979. De acordo com Fausto (1995), o país vivia um dos momentos 
políticos mais tenebrosos da sua história e alcançava êxitos na política econômica. As finanças públicas foram reequilibradas, a inflação foi refreada e a indústria voltou a ganhar fôlego. Era o chamado "Milagre Econômico". O general Emílio Garrastazu Médici sucede Costa e Silva na presidência e acompanha o declínio da luta armada, em meados de 1970. A inflação reduzida permitiu atenuar o impacto social da concentração de renda, abrir-se para o comércio exterior e impulsionar a indústria nacional. Porém, o país se destacaria no cenário mundial por indicadores muito baixos de saúde, educação e habitação. O período de governo militar se estendeu até o início da década de 1980.

O breve recorte histórico serve de pano de fundo para a análise de como a TV brasileira se desenvolveu tanto economicamente quanto a despeito da indústria de entretenimento e conteúdo. Além disto, sua vocação para educar a distância esbarrou em questões políticas e sociais que variaram - e variam - de acordo com objetivos de governo para a educação pública de massa. Ao tratar de TV educativa estatal estes olhares macroeconômicos e sociais são determinantes para compreender seu papel educativo e sua própria subvenção. A partir deste entendimento, é possível prosseguir na análise do percurso histórico da TV no país.

Apesar de, inicialmente, ser objeto das classes economicamente privilegiadas, a televisão nasceu com o propósito da comercialização. Fato que ajudou a constituir a linguagem do meio.

No Brasil, o serviço de radiodifusão trata-se de uma concessão do Poder Público Federal a pessoas físicas ou jurídicas, de direito público ou privado, de executar e explorar, em seu nome ou por conta própria, serviços de telecomunicações durante prazo determinado. De acordo com a legislação ${ }^{16}$ que rege o setor, a radiodifusão tem finalidade educativa e cultural, mesmo em seus aspectos informativo e recreativo, sendo considerada de interesse nacional, permitindo apenas a exploração comercial desta, na medida em que não prejudique este interesse e finalidade. Desta maneira, a televisão brasileira nasce outorgada pelo Estado, mas explorada com fins comerciais, sustentadas por capital privado. Como tal, vista como empreendimento que deve resultar em lucro, esta deve retornar os investimentos. Assim sendo, a programação passou a

16 Decreto $\mathrm{n}^{\mathrm{o}}$ 52.795, de 31 de outubro de 1963. Disponível em: http://www.planalto.gov.br/ccivil_03/decreto/Antigos/D52795.htm. Acesso em: 15 de jan. 2015. 
contar com anunciantes, considerando como sucesso o alto índice de audiência, a exemplo do que já havia sendo praticado em emissoras de diversos países.

Apontado como um dos nomes mais importantes da televisão brasileira, Walter Clark ${ }^{17}$ fez o mesmo caminho de tantos radialistas. Chegou à TV Rio, trazendo na bagagem a experiência na rádio Tamoio e na agência de publicidade Interamericana, e construiu aquilo que iria se tornar determinante à TV do país até hoje: a grade estruturada de programação.

Walter Clark foi trabalhar com o dono da TV Rio, João Batista do Amaral, o Pipa, em 1956, logo após a emissora entrar no ar. De acordo com o depoimento de Clark, a TV Rio não tinha dinheiro para implementar o sonho do proprietário: criar uma programação em rede, para todo o país, unindo várias outras pequenas estações e retransmissoras. Além disto, Pipa tinha outro desejo: investir em programação educativa. O relato torna-se precioso no entendimento do que vai se constituir entretenimento, conteúdo educativo e relação com a audiência:

Ele queria montar uma TV educativa na programação diurna, vendendo os telecursos para outras estações que quisessem entrar em rede ou para o governo e ainda as empresas que quisessem alfabetizar seus empregados, com isso obtendo abatimento no imposto de renda. Iniciativa privada e governo criariam uma rede de telepostos, conectados à TV Rio e suas afiliadas. [...] Boas intenções e ideias visionárias não produzem necessariamente resultados positivos. Uma rede de televisão educativa, num país de analfabetos, era certamente um projeto relevante, meritório, mas estava na cara que daria mais problema que dinheiro. A estação ocupava todo o prédio do antigo Cassino Atlântico [...] tinha dois estúdios gigantescos, também maiores que do que os de muita emissora recente. Mas para a área de entretenimento, ficava apenas um terço do espaço total. O resto, a maior parte, era ocupado pelo projeto da telescola. Era uma coisa megalomaníaca, baseada na experiência da telescola italiana, que deu muito certo e erradicou o analfabetismo no sul da Itália. Quem pilotava era Alfredina de Paiva e Souza, a grande mentora da televisão educativa no Brasil, hoje um nome muito cultuado nesse setor. [...] Deu tudo errado. Para começar, o equipamento disponível era insuficiente para atender o projeto da telescola, que foi postergado. (CLARK, PRIOLLI, 1991, pp. 73-74)

É interessante notar que neste momento já começa o malogro da televisão educativa que perdura até os dias atuais com recursos escassos e conteúdo educativo preterido em relação ao entretenimento compreendido como diversão.

Com o objetivo de atrair anunciantes e fazer caixa, Walter Clark e outros diretores conseguiram convencer o dono da TV Rio a investir numa programação

\footnotetext{
${ }^{17}$ Walter Clark teve papel extremamente relevante não apenas na história da televisão comercial brasileira, em especial da TV Globo, onde trabalhou a maior parte de sua vida. O radialista foi presidente da Fundação Roquette-Pinto e diretor da TV Educativa - TVE. De 1993 a 1995, concebeu e criou a MultiRio, sendo seu primeiro presidente.
} 
de entretenimento popularesco, baseado nos sucessos de audiência do rádio, deixando de lado a pretensão de atingir um público mais qualificado. "Assim com uma série de programas apelativos, a TV Rio foi descobrindo o doce sabor do sucesso e surgindo no mapa como uma televisão alternativa à Tupi" (CLARK, PRIOLLI, 1991, p.77). A ideia inicial era aumentar as receitas, conquistar a audiência com os programas populares e depois ir conduzindo o público, gradualmente, a uma programação melhor. Com esses choques internos de opinião, a TV Rio tinha uma programação desestruturada.

O depoimento extraído da autobiografia de Clark é curioso, pois é ele quem irá - anos depois - criar a MultiRio, justo uma produtora de conteúdo educativo, diretamente ligada à escola, e sem fins lucrativos.

Walter Clark conta que a estrutura de exibição da televisão brasileira, e consequente linguagem, ganhou contornos mais estruturados quando o presidente Jânio Quadros, ao tomar posse, decidiu interferir na legislação do setor, afinal, concessão pública outorgada pelo governo federal. O decreto ${ }^{18}$ reconhecia a natureza educadora da televisão e moralizava tanto o departamento comercial quanto a produção de conteúdo, tornando clara a censura ao que passaria ser veiculado. De acordo com Clark, foi neste período que a TV do país começou a contar seu tempo em segundos, incorporando o conceito de "segundagem". Os intervalos comerciais estavam proibidos de ultrapassar três minutos de duração com filmes ou slides. Poderiam chegar a oito, mas os cinco minutos excedentes seriam preenchidos com comerciais ao vivo. Com isto, os formatos dos programas e as grades de programação passaram a cronometrar o tempo de exibição do conteúdo. E como já vinha ocorrendo em países pioneiros em televisão, um ritmo ágil provido de dinamismo visual começou a determinar a linguagem televisiva.

\section{1.}

\section{A linguagem da televisão}

Todas essas técnicas para desenvolver o veículo televisão acabaram por demonstrar que televisão é linguagem. E uma linguagem específica com códigos

\footnotetext{
${ }^{18}$ Decreto $\mathrm{n}^{\text {o }}$ 29.783, de 19 de julho de 1961. Disponível em: http://www2.camara.leg.br/legin/fed/decret/1960-1969/decreto-51134-3-agosto-1961-390748publicacaooriginal-1-pe.html. Acesso em: 15 de jan. 2015.
} 
próprios. A textualidade televisiva é formada por atributos e objetivos, considerando a essência do meio, tais como:

1) Entretenimento e informação.

Todas as produções devem entreter a audiência de alguma forma, ou simplesmente não haverá audiência. Haverá pessoas que se esqueceram de desligar seu televisor, ou estão aguardando o que vem depois. De fato, a definição mais útil para entretenimento é alguma coisa que as pessoas querem ver. Não implica entreter só no sentido de 'vamos sorrir e cantar'. Pode interessar surpreender, divertir, chocar, estimular ou desafiar a audiência, mas despertar sua vontade de assistir. Isso é entretenimento. [...] Informar significa possibilitar que a pessoa, no final da exibição, saiba mais sobre algum coisa do que ela sabia no começo do programa. (WATTS, 1990, p. 20)

2) Dependência da imagem.

Watts (1990) ressalta que em televisão é preciso raciocinar por imagem, o que significa pensar que qualquer história que seja contada, uma notícia ou uma novela, deve ser construída com sequências de imagens relacionadas entre si, constituindo uma lógica. Porém, vale a ressalva de que a mesma imagem que auxilia a compreensão do que é exibido, pode desviar a atenção do que está sendo dito, como explica Curado ${ }^{19}$ :

O público de televisão não está lendo a notícia, está ouvindo e vendo. O telespectador está olhando o apresentador, ou o repórter, ou o entrevistado e tentando apreender o que eles dizem. No instante em que toma conhecimento da notícia, o espectador não pode interromper o jornalista pedindo-lhe que esclareça algum ponto não compreendido. Não pode voltar no tempo e recuperar uma frase ou uma informação que perdeu, a não ser que tenha gravado o programa. (CURADO, 2002, p. 19)

A supremacia da imagem é considerada perigosa por Bourdieu (1997).

Segundo o autor, o uso habitual da imagem pela televisão implica no perigo político de que a imagem tem o poder de produzir um efeito real, "ela pode fazer ver e fazer crer no que se faz ver" (p.28). Esse poder pode criar ideias, representações e grupos.

$\mathrm{E}$, insensivelmente, a televisão que se pretende um instrumento de registro torna-se um instrumento de criação da realidade. Caminha-se cada vez mais rumo a universos em que o mundo social é descrito-prescrito pela televisão. A televisão se torna o árbitro do acesso à existência social e política. (BOURDIEU, 1997, p. 29)

A criação desta realidade resulta da condição de que imagem e sentido não estão dissociados. Fischer (2001) explica que a imagem possuiu dois domínios: o

\footnotetext{
${ }^{19}$ Olga Curado - Jornalista. Trabalhou, nos anos de 1980 e 1990, nos jornais impressos Jornal do Brasil, O Estado de S.Paulo e O Globo. Na Televisão, Olga Curado trabalhou nas redações da TV Manchete e TV Globo, onde assumiu os principais telejornais da emissora.
} 
material (no caso da TV, luz); e o da significação, cujos sentidos e "imagens" sobre si mesmo e sobre o mundo que cada um de nós, internamente, produz e que nos constituem formando um sistema de significados próprio de cada cultura.

3) Efeito lacunar.

Marshall McLuhan (1969) classificou a TV como um meio frio, ou seja, um meio que aguça vários de nossos sentidos, ao mesmo tempo, e em baixa definição. É um meio onde o espectador tem de despertar a pluralidade de sentidos ante aos rasos dados emitidos, que oferecem pouca informação, deixando lacunas de compreensão para serem preenchidas pelo telespectador. Diante da TV, nossos sentidos são provocados a dar significados à informação. A TV oferece o discurso lacônico e com isto provoca o extraordinário grau de participação da audiência. Segundo um autor, um meio quente traz informação suficiente para "esquentar", "inflamar" o usuário produzindo nele uma ação diante do dado mencionado. O meio frio é aquele meio que, literalmente, tem a capacidade de colocar o usuário no modo latente, honífero ou sob controle, sendo conduzido pelo meio.

4) Meio sensório.

Quando o telespectador assiste a televisão, ele é levado para dentro da TV, porque ele é a tela. No cinema, o público olha para a tela onde a luz é projetada e assiste as imagens. Com a televisão o sujeito é a tela, pois a luz é emitida direto do aparelho para as retinas do espectador. Por isto, Marshall McLuhan (1969) vai dizer que a televisão é um meio sensorial, porque além de despertar os sentidos para a cognição das mensagens, a projeção da luz "toca" o espectador, configurando a qualidade áudio-tátil que McLuhan vai atribuir à TV.

5) Fragmentação.

A televisão é um meio instantâneo, ágil, sendo inapropriada para comunicação de informações detalhadas. O tempo na televisão é marcado pela escassez. Com isto, a concisão vai permitir que mais conteúdo seja apresentado ao espectador, ainda que, geralmente, sem aprofundamento significativo.

Um telejornal diário tem em média 24 minutos de duração, descontados os breaks. Este tempo é preenchido com matérias cuja duração costuma variar de 1:05" a 1:30". Curado descreve que dentro deste modelo, o texto do apresentador anunciando a matéria dura cerca de 15 segundos; o do repórter entre 20 e 30 segundos; a sonora ou a fala do entrevistado, aproximadamente 15 segundos; a passagem do repórter (participação de vídeo do repórter trazendo informações) 
dura em torno de 20 segundos; a fala de um segundo entrevistado mais 15 segundos e o texto final de encerramento, cerca de 15 segundos. Todo o conteúdo é picotado, ainda que formando uma lógica narrativa.

Essa fragmentação permite ofertar informação e entretenimento non stop, mantendo a audiência. Pierre Bourdieu (1997, p. 23) critica a televisão justamente por este modo de produção e superficialidade da linguagem, quando comenta “ora, o tempo é algo extremamente raro na televisão. E se minutos tão preciosos são empregados para dizer coisas tão fúteis, é que essas coisas tão fúteis são de fato muito importantes na medida em que ocultam outras coisas".

Em análise sobre a televisão, a partir da semiótica, Duarte (2004) coloca que os textos midiáticos são marcados por rupturas de certas estruturas lógicas da produção de textos, ainda que esse "estilhaçamento" não represente a ausência de lógica, mas o emprego de formas diferentes de racionalidade.

... em instância mais superficial, a do esquema narrativo, o encadeamento dos percursos é explicado por seu caráter lógico-sintático-semântico. Trata-se de uma grade cultural de leitura de mundo, sustentada por relações de pressuposição e implicatura - há coerência entre qualificação, ação e sanção - pautadas por uma lógica que diz de causas e consequências, de meios e fins, etc. e é essa lógica que, pelo menos em nível mais superficial, está em causa nos textos midiáticos com que se trava contato diariamente, cuja conformação, bastante peculiar, persegue o vago, o indefinido, o ambíguo, o indistinto, o fragmentado, o reiterado, o superposto, deixando à recepção a tarefa de preencher as lacunas, de precisar os sentidos, de estabelecer as relações lógicas. (DUARTE, 2004, p. 23)

A relação entre produtores de comunicação e audiência ocorre sob uma condição de contrato entre as partes ou um jogo. Duarte (2004) explica que os interlocutores buscam "com-vencer" um ao outro, obrigando-o a partilhar de sua vitória, numa ligação que requer manipulação e persuasão, feitas de modo a não serem percebidas ou mal compreendidas pelo interlocutor. Como tal, o jogo possui regras. Fora destas, a liberdade irrestrita do interlocutor seria sempre anterior à aceitação da participação, condição que estabelece as regras, possibilidades e limites de movimentação.

Bourdieu (1997) convenciona de "violência simbólica" a violência que se exerce com a cumplicidade tácita dos que a sofrem e dos que a exercem, afirmando que uns e outros são inconscientes de sofrê-la ou exercê-la. Produção e audiência são subjugadas mutuamente.

A cumplicidade entre televisão e telespectador traz à luz uma questão fundamental para todos os tipos de emissoras, em especial a educativa, que 
convive desde o início com questões relativas à baixa audiência, fator discutido no estudo de caso.

6) Ambiente envolvente; Intimidade.

A TV é um meio dotado de intimidade. Segundo Watts (1990), um discurso eficaz dirigido aos telespectadores requer falar como se estivesse conversando individualmente com cada um deles e não enviado a milhões. "Se as respostas forem redigidas antecipadamente, essa intimidade será perdida criando um distanciamento em relação ao telespectador" (1990, p.72).

McLuhan (1969) observa que a TV possui como imperativo o total envolvimento sensório com a imagem. É um meio envolvente. De acordo com o teórico, a TV envolve de tal forma, que é preciso estar com ela, diante dela. Pois afinal, para preencher as lacunas é preciso estar atento ao que falta. Esta vocação de manter o usuário diante da máquina e interpretada por McLuhan como uma sutil, porém, astuciosa inversão de papéis.

O teórico segue explicando que os pontos que formam a imagem na televisão causam imprecisão na informação transmitida. E a consequente imagem em movimento também, exigindo que a cada instante o telespectador se esforce para preencher os espaços da trama. Por isto, a TV teria por linguagem a inclinação por enquadramentos fechados, os closes, reforçando o caráter envolvente, intimista do meio.

Por tanto, a televisão deve ser compreendida como linguagem. E como tal possui uma gramática particular, elaborada por códigos e vocabulários peculiares tais como gêneros, formatos e estilos.

\section{2.}

Grade de Programação, Gêneros e Formatos

O conteúdo na televisão está disposto numa grade de programação. A grade vai organizar os programas exibidos pela emissora de forma a ofertar ao espectador produtos que o mantenham conectado o maior número horas possível. Estes programas são ordenados conforme dias e horários, variando segundo o público. Além dos programas, a grade é articulada por chamadas e comerciais. Desta forma, é princípio de programação o esforço e estratégia para que um 
programa mantenha o espectador e estimule-o a assistir ao próximo programa a ser exibido, fazendo com que a audiência permaneça efetivamente no canal.

A grade reflete também percepções e objetivos da emissora a respeito da audiência, considerando o ambiente onde ambas estão imersas. Nela é possível observar o texto televisivo de forma estruturada, evidenciando sentidos, propósitos e valores tanto do público em relação à emissora, quanto desta à audiência .

As emissoras falam de si através de suas programações. Partindo da pressuposição de existência de intencionalidade em qualquer ato comunicativo, evidencia-se a responsabilidade da emissora pelas escolhas de programas e de encadeamentos, que, evidentemente não são arbitrárias. Tais escolhas, aliás, são fortes componentes da construção da identidade de uma emissora enquanto ser do mundo. [...] Assim, na elaboração de uma grade de programação, os fatores externos de ordem cultural, social e econômica são determinantes, definindo dias para exibição de cinema ou futebol, variedade ou humorismo, jogos ou concursos. (DUARTE, 2004, p. 45)

Fischer (2001) acrescenta que a TV evidencia pontos de vista de pessoas concretas como produtores, roteiristas, jornalistas, atores, enfim, os profissionais que fazem televisão, a respeito de diversos assuntos. A autora afirma que ao assistir TV, estes olhares destes sujeitos também nos olham. É possível enxergar ali o que somos ou não, o que negamos ou acreditamos, desejamos ou rejeitamos. A televisão nos convida a olharmos para nós mesmos.

A grade organiza este olhar determinando quem assiste o que, em que dia e horário. E se a programação evidencia a estrutura hierárquica do todo, serão os programas a forma de embalar o discurso segmentado a cada parcela da audiência.

Os programas de televisão são separados por categorias que contemplam gêneros. Essa divisão por categorias não identifica apenas os produtos, mas encaixa-os na dinâmica industrial assumida pelo mercado de produção. De acordo com Aronchi ${ }^{20}$ (2004), existem três categorias que abarcam a maioria dos gêneros: entretenimento, informativo e educativo, havendo uma quarta categoria denominada pelo autor como "especiais", que compreende os programas de minorias étnicas, agrícolas, religiosos, televendas e outros.

20 José Carlos Aronchi de Souza - Professor e Doutor em Ciências da Comunicação pela Universidade de São Paulo. Especialista em Uso do Vídeo na Educação pela University of London, Inglaterra. Trabalhou nas TVs Globo e Cultura. Pesquisa o desenvolvimento da TV Digital e conteúdo para multiplataformas digitais e EAD - Educação a Distância, Produtos e processos de Inovação e Empresas Startups. Em 2010, recebeu o Prêmio Melhor Inovação Interatividade para a TV Digital, da Sociedade Brasileira de Engenharia de Televisão, com o aplicativo Roda dos Gêneros da TV Digital. 
Os gêneros são conjuntos de características organizadas, ordenadas classificadas de acordo com a forma, estilo, proposta. Aronchi apresenta um contraponto a esta definição como uma crença arbitrária e cultural, muitas vezes não compartilhadas entre televisão e audiência. Deste modo, gênero é entendido como estratégias de comunicabilidade, fatos culturais e modelos dinâmicos, articuladas com a dimensão histórica do espaço de produção, abrangendo numa mesma matriz cultural referencias comuns a produtores e emissores e ao público receptor.

Dividindo então em cinco categorias apresentadas pela televisão brasileira, é possível classificar os gêneros como:

a) Categoria Entretenimento: programas de auditório, colunismo social, culinário, desenho animado, docudrama, esportivo, filme, game show, humorístico, infantil, interativo, musical, novela, quiz, reality show, revista, série, sitcom, talk show, teledramaturgia, variedades e western (faroeste).

b) Categoria Informação: programas de debate, documentário, entrevista, telejornal.

c) Categoria Educação: educativo, instrutivo.

d) Categoria Publicidade: chamada, filme comercial, programas políticos, de sorteio, televendas.

e) Categoria Outros: especial, eventos, religioso.

Os gêneros abrangem formatos ${ }^{21}$, que ajudam a definir objetivos e a eficácia da comunicação. A seleção dentre estes passa pelo debate sobre entreter e informar.

Duarte (2004) explica que entre as características essenciais do texto televisivo, independente do gênero, está a recorrência a estratégias de espetacularização. É possível notar traços, tons, responsáveis por efeitos de sentido produzidos como entretenimento, humor, emoção e ausência de problematização. De acordo com a autora, a TV precisa ser assistida, ou seja, há toda uma intencionalidade para fazer com que o espectador pare diante dela e

21 São formatos utilizados pelas emissoras no Brasil: Ao vivo; Auditório; Câmera oculta (pegadinhas); Capítulo; Debate; Depoimento; Documentário; Dublado; Entrevista; Episódio; Esquete; Game show; $\quad$ Instrucional; Interativo; Legendado; Mesa-redonda; Musical; Narração em off; Noticiário; Quadros; Reportagem; Revista; Seriado; Talk show; Teleaula; Telejornal; Teletexto; Testemunhal; Videoclipe; Vinheta; Voice over. Os formatos podem apresentar a variação de transmissão ao vivo ou gravado, tanto em estúdio quanto em externa. (ARONCHI, 2004). 
assista ao espetáculo. E ao competir com as tarefas diárias, seduz com prazer a audiência, fazendo-se escolhida entre tantos outros afazeres. Entretenimento que segundo sua análise não se contradiz com a informação. Destarte, as funções informativa, pedagógica e politico-ideológica da televisão não se constituem aspectos distintos, pois são neutralizados pela espetacularização que garante a função de entretenimento. Daí as chamadas como show de notícias, show de reportagem, show de gols que costumam aparecer com recorrência.

O discurso televisivo também sofre influência do aparato tecnológico. Gêneros e formatos existem conforme o desenvolvimento e sofisticação dos meios técnicos de produção, circulação e consumo das mensagens. Desta maneira, a tecnologia acentua ou não a condição de atração, espetáculo a ser assistido.

Duarte (2004) afirma que dizer que um programa é informativo ou de entretenimento é falar praticamente nada sobre ele, pois todos os programas televisivos informam e entretém.

Segundo o dicionário, entretenimento é diversão, mas também passatempo, distração. Ora, informar-se não é também uma forma de distrair-se? Mais ainda, entreter também significa demorar-se, mitigar, o que remete a procedimento semelhante e desejável no consumo de informações. No que exatamente, entreterse se opõe então a informar-se? Nenhum subgênero dito informativo escapa à espetacularização, do magazine ao debate, passando pelos telejornais e documentários, sejam eles transmissões diretas em tempo real ou não. O que pensar então, nesse contexto, da tradicional oposição real/ficção? Todas as emissões televisivas são produções discursivas que se materializam em textos. Não são jamais o real. (DUARTE, 2004, p.66)

Entender a estrutura e a linguagem da televisão é fundamental para mergulhar nas questões trazidas por este estudo a respeito daquela que se configura uma programação educativa e suas perspectivas futuras. 


\section{3.}

\section{TV Educativa: escola na TV?}

\section{1. Construindo a TV Educativa}

A televisão a serviço do ensino, empregada em salas de aula de escolas e universidades ou outros espaços de aprendizagem, despontou num primeiro momento como ferramenta e modalidade de ensino a distância, empregada por governos de países europeus e Estados Unidos. Entre os anos de 1932 e 1939, a universidade de Iowa fez seus primeiros experimentos com TVE, colocando no ar, somente em 1950, a primeira televisão educativa americana, a WOI TV. Do outro lado do Atlântico, a britânica BBC, inaugurada em 1930, tomou por premissa promover a educação, a aprendizagem e a cidadania, com base no tripé informação-educação-entretenimento. A iniciativa da BBC foi seguida pela televisão francesa, em 1950, e italiana, em 1958. Na década de 60, foi vez de nações comunistas como Yugoslávia, Polônia e China transmitirem conteúdos educativos pela TV. Na Ásia, o Japão tornou-se o primeiro país do mundo a integrar plenamente a televisão a sua estrutura escolar, desde o jardim de infância às universidades. Na América Latina, a Colômbia começou seu projeto de televisão educativa, em 1950.

No Brasil, Getúlio Vargas concedeu outorga de canais educativos para várias instituições do então Distrito Federal, em 1952. Através do decreto 30.832, Edgar Roquette-Pinto ${ }^{22}$, líder de um grupo de empreendedores, conseguiu a concessão do canal 2 para estabelecer por intermédio da Rádio Emissora Roquette-Pinto, uma estação de radiotelevisão. Mas os planos foram frustrados cinco anos depois por outro decreto presidencial, instituído por Juscelino

\footnotetext{
${ }^{22}$ Edgard Roquette-Pinto - Professor na Seção de Antropologia, Etnografia e Arqueologia e diretor do Museu Nacional. Participou do movimento de renovação educacional no Brasil, assinando o Manifesto dos Pioneiros da Educação Nova, de 1932. Foi grande incentivador da divulgação científica, valendo-se de diferentes estratégias e meios de comunicação, como livros, exposições, cinema e rádio, criando bibliotecas e filmotecas, programas de rádio e filmes educativos e de divulgação científica. Idealizou a Sociedade Brasileira de Ciências (atual Academia Brasileira de Ciências); idealizou e participou da Rádio Sociedade do Rio de Janeiro, cujo objetivo era difundir assuntos culturais e científicos. Criou a Rádio Escola Municipal do Rio de Janeiro. Dirigiu o Instituto Nacional de Cinema Educativo (INCE) de 1936 a 1947, incentivando a participação de cientistas na elaboração dos filmes e a escolha de temáticas científicas e técnicas.
} 
Kubitschek, que reviu as concessões e redistribuiu os canais, adiando o sonho de uma emissora exclusivamente educativa.

Milanez $^{23}$ (2007), em sua pesquisa sobre a TVE, aponta que a discussão sobre as pressões políticas e boicote à implantação de uma televisão exclusivamente educativa fora temas de uma entrevista de capa com o professor Fernando Tude de Souza, na revista Publicidade e Negócios, de 1960. Tude havia formado um grupo com Roquette-Pinto, José Oliveira Reis e Lauro de Medeiros para estudar a viabilidade de uma emissora educativa no país. Era a Comissão Técnica de Televisão, CTT. Tudo já estava planejado, equipamentos comprados e os estúdios estavam em fase final de construção. A prefeitura do Distrito Federal, hoje, Rio de Janeiro, era parceira, ajudando a custear o projeto. O grupo chegou a participar de um seminário sobre educação promovido pela Unesco, quando os entusiastas foram surpreendidos, conforme relato de Tude de Souza:

Desembarquei no Rio numa quarta-feira (novembro de 1952). No princípio da semana seguinte o prefeito João Carlos Vital foi levado a se exonerar, sendo imediatamente substituído pelo cel. Dulcídio Cardoso. No outro domingo, fui acordado em minha casa com um telefonema do prof. Roquette-Pinto, que me disse com voz desolada: Meu filho, já leu o Correio da Manhã de hoje? Você foi demitido. E agora? E a partir desse instante ninguém mais falou comigo ou com Roquette-Pinto sobre televisão educativa no Rio de Janeiro. O nosso projeto que estava praticamente concretizado, desapareceu dentro das gavetas do Palácio da Guanabara, sem que nenhum outro prefeito quisesse se preocupar com o assunto. (SOUZA, 1960, apud MILANEZ, 2007, p. 23)

$\mathrm{Na}$ redistribuição dos canais feita por Juscelino Kubitschek, o canal 2 foi cedido à Rádio Mayrink Veiga, mais tarde, TV Excelsior. O canal 2 só voltou a ser novamente um projeto de televisão educativa em 1973, através do decreto 72.634, outorgando à Fundação Centro Brasileiro de Televisão Educativa (FCBTVE) a concessão para transmissão de som e imagens com esta finalidade. A TVE seria, então, a maior e principal representante desta modalidade de televisão do país, entrando definitivamente no ar em 1977.

O projeto de uma emissora educativa, em rede, distribuindo a programação em todo o Brasil teve de esperar até 1973. Contudo, as experiências efetivas com televisão educativa surgiram entre as décadas de 1960 e 1970. Desde 1958, a TV

\footnotetext{
${ }^{23}$ Liana Maria Milanez Pereira - Jornalista. Mestre em Ciências da Comunicação, pela Escola de Comunicações e Artes (ECA), da Universidade de São Paulo (2005). Trabalhou na área de Comunicação, incluindo rádio, jornal, revista, televisão, agência de notícias, assessoria de imprensa, além de rádios e televisões públicas. Foi diretora-fundadora da rádio FM Cultura de Porto Alegre. Em 2003, foi presidente da TVE-RS e gerente executiva da Rádio MEC - Rio de Janeiro (ACERP/EBC) entre maio de 2007 e dezembro 2011.
} 
Educativa da Universidade de Santa Maria (RS) produzia programas educativos. A TV Escolar de São Paulo, a Fundação João Batista do Amaral e a Universidade de Cultura Popular no Rio de Janeiro também ajudaram a compor o mosaico da televisão educativa brasileira. Em 1967, entrou no ar a primeira emissora educativa, a TV Universitária de Pernambuco. No início, a vocação era educação a distância, com base na escolarização formal.

Milanez (2007) explica que em 1961, a TV Rio colocou no ar, durante dois anos, um curso de alfabetização de adultos. Um ano depois, Gilson Amado ${ }^{24}$, por meio da Universidade de Cultura Popular transmitiria cursos experimentais do Art. 99 pela TV Continental e Emissoras Associadas. Em 1963, a Secretaria de Educação do estado de São Paulo assinou um convênio com a TV Cultura para a produção de 10 horas semanais de programação educativa, incluindo educação básica, $5^{\text {a }}$ série primária, música, arte, literatura infantil além de cursos de capacitação para professores em matemática moderna, ciências, desenho e ensino de português. No mesmo ano, Paulo Freire desenvolveu seu método de alfabetização em massa. A TV, assim como o rádio, começou a cumprir seu papel de educação a distância.

Herança direta do rádio educativo, em voga desde os anos 20 , a televisão educativa começou com propósito pedagógico, transmitindo aulas televisadas, em circuito fechado ou aberto, compartilhando conteúdos escolares em cidades distantes dos centros urbanos e carentes de escolas, assim como o seu predecessor.

A busca por um modelo e usos educativos do rádio fascinou intelectuais e empreendedores, que se dedicaram a implementar a radioeducação no Brasil. Coelho $^{25}$ (2012) explica que o início da década de 1930, o país assistiu a um intenso debate sobre o papel do rádio na educação envolvendo intelectuais como Roquette-Pinto, Francisco Venâncio Filho, Edgar Sussekind de Mendonça, Miguel Ozório de Almeida, Dulcídio Pereira, Lourenço Filho e Anísio Teixeira. A proposta da radioeducação chegou a ser defendida e pleiteada no Manifesto dos Pioneiros da Escola Nova, reconhecendo que a escola deveria valer-se em seu

${ }^{24}$ Gilson Amado - Jornalista, professor, educador e radialista. Fundou e presidiu a Fundação Centro Brasileiro de TV Educativa, FCBTVE, cuja finalidade era produzir, adquirir e distribuir material audiovisual destinada à radiodifusão educativa.

${ }^{25}$ Patrícia Coelho da Costa - Doutora em Educação pela Universidade de São Paulo (2012). Professora da Pontifícia Universidade Católica do Rio de Janeiro. Especialista em Educação, com ênfase em Fundamentos da Educação, História da Educação, Radioeducação, Intelectuais e Cultura Material Escolar. 
proveito de todos os recursos, inclusive a imprensa, o disco, o cinema e o rádio, em face do alcance às populações distantes do centro urbano. De acordo com Coelho, a radioeducação carioca ocorreu por intermédio da Rádio Escola Municipal, a PRD5. À frente da experiência, Roquette-Pinto ficou responsável pela contratação de pessoal, como redatores, locutores e técnicos. Um desafio, pois havia poucas alternativas no mercado comercial. Roquette-Pinto, então, teve de formar radioeducadores: professores capazes de comunicar e comunicadores aptos a educar. "Independente da experiência anterior em radiofonia, era dada preferência aos candidatos que compartilhassem os preceitos do rádio como instrumento de educação" (COELHO, 2012, p. 100).

O papel do rádio na escolarização do país gerou uma das principais experiências educativas na radiofonia: o Movimento de Educação de Base, o $\mathrm{MEB}^{26}$, programa desenvolvido pela Conferência Nacional dos Bispos do Brasil CNBB, cujo objetivo era ministrar educação básica às comunidades das áreas subdesenvolvidas do Norte, Nordeste e Centro-Oeste do país, por meio de programas radiofônicos especiais de recepção organizada. As escolas radiofônicas funcionavam em salas paroquiais, fazendas e barracões. As aulas eram produzidas e ministradas por professores-locutores, e monitores escolhidos nas próprias comunidades, se encarregavam de trabalhar os conteúdos com os alunos, colegas de campesinato. O MEB foi além do ensino escolar e tornou-se uma proposta de empoderamento e conscientização do trabalhador rural através da educação, ratificando o saber do homem do campo na construção de novos conhecimentos e superação das injustiças. Todavia, apesar dos esforços de um diálogo entre a escola radiofônica, monitores e alunos, por meio de cartas lidas e respondidas ao vivo, o feedback tão necessário ao processo educativo - e também alvo de críticas quanto à televisão — foi objeto de discordância de pontos de vista entre seu coordenador, Osmar Fávero, e Paulo Freire, como descreve Baumworcel ${ }^{27}$ sobre entrevista com Fávero:

\footnotetext{
${ }^{26}$ Surgido no início dos anos 1960, por influência das escolas radiofônicas, o MEB nasceu com outros programas de expressão popular da época como o Movimento de Cultura Popular, de Recife; a campanha De pé no chão também se aprende a ler, em Natal; Centro Popular de Cultura; Campanha de Educação Popular da Paraíba e Sistema Paulo Freire de alfabetização, que resultou no Programa Nacional de Alfabetização (FÁVERO, 2004).

27 Ana Baumworcel - Jornalista, Doutora em Educação pela Universidade Federal Fluminense (2012). Professora e pesquisadora da área de Rádio do Departamento de Comunicação Social da Universidade Federal Fluminense. Especialista em Comunicação, com ênfase em Mídia Sonora,
} 
Paulo Freire mostrava uns desenhos que tinham sido feitos para ele, quando eu disse que era do MEB, trabalhava com as escolas radiofônicas, e ele fez uma crítica pouco piedosa. Falou que as escolas radiofônicas do MEB eram como Saci. Só tinham uma perna de ida e não tinham outra perna para voltar. Claro, na perspectiva de diálogo dele. (BAUMWORCEL, 2008, p. 1)

Estes radialistas e empreendedores chegaram à TV trazendo suas experiências alcançadas no rádio. Gilson Amado escreveu em 1971, que a natureza do emprego e a vocação da televisão educativa no Brasil era a de proporcionar a educação escolar direta aos analfabetos e todos aqueles que estavam fora da escola por motivos como a ausência de unidade escolar próxima a residência. Conforme a defesa de Amado, enquanto que na Europa, nos Estados Unidos e no Japão, a televisão teria sido usada para complementar o ensino fornecido amplamente pelo governo à população, enriquecendo o processo educativo, no Brasil, a televisão educativa deveria testar sua aptidão didática.

Tem assim o Brasil condições para realizar a primeira experiência em larga escala de utilização da TV para ensinar e habilitar, com títulos formais, grandes parcelas da coletividade brasileira, adolescentes e adultos, maiores de 16 e 18 anos, se aprovada a reforma de ensino fundamental proposta pelo Ministério da Educação e Cultura.

Êsse processo de educação de adultos pode servir para fazer do Brasil o laboratório ideal para o teste definitivo da TV, não apenas como instrumento complementar do ensino organizado, mas como veículo de educação direta da multidão interessada nos múltiplos campos da recuperação pedagógica, é claro que apoiado esse programa educacional em sistemas fundamentais de infraestrutura, recepção organizadas, assistência de monitores, material didático de apoio, etc. (AMADO, 1971, p. 19)

O projeto de televisão educativa defendida por Gilson Amado ainda contemplaria a formação e aperfeiçoamento de professores leigos, à época, dos ensinos primário e secundário ${ }^{28}$.

\subsection{1.}

A complexa definição de TV Educativa

Ainda que a televisão tenha sido empregada com a premissa de levar aos lugares longínquos a sala de aula, é preciso clarificar que não existe um modo

trabalhando os seguintes temas: rádio, jornalismo, história do rádio, rádio educativo, juventude e educação.

${ }^{28}$ Entre os cursos oferecidos estavam aulas de orientação de alfabetizadores do Mobral; Moral e Civismo; Educação Familiar, envolvendo os conflitos entre pais e filhos; Educação Física; Iniciação Artística e Cultural; Preparação de mão de obra domiciliar; programas dirigidos à juventude; Faixa de Fronteira, cobrindo todas as áreas de educação coletiva das populações fronteiriças (AMADO, 1971). 
puro de designação para TV, mesmo que esta seja comumente nomeada como educativa, escolar, cultural ou comercial. O que vai diferenciar estes modelos são os objetivos, as intenções, a veiculação, os públicos e as receitas.

Machado $^{29}$ (2001) define por televisão um plural repertório de possibilidades de produção, distribuição e consumo de sons e imagens eletrônicos. Deste modo, compreende tudo aquilo que se desenvolve e ocorre em grandes ou pequenas emissoras comerciais ou estatais, abertas ou pagas, produtores independentes e grupos de intervenção em canais de acesso público.

Bullaude $^{30}$ (1967) alega que a definição de televisão educativa como gênero que não é de entretenimento ou hebetude, significa dizer que a definição pelo que "não é" resulta insuficiente. Para o autor, não há fórmula concreta e definitiva para responder a pergunta: o que é TV educativa? Ele esclarece que as experiências americanas neste segmento tentaram estabelecer diferenças e convencionou-se chamar de televisão instrutiva o tipo de TV educativa relacionada com o ensino sistemático. E TV educativa, o tipo que se orienta segundo a educação assistemática.

Instrucional, educativa e cultural. $\mathrm{O}$ que parecem adjetivos que poderiam caracterizar a TV educativa são categorias de emissoras que diferenciam propósitos que colaboram para a polissemia de uma definição sobre televisão educativa. Essa classificação pode ser encontrada em modelos de televisões públicas em diversos países europeus, como França, Portugal e Espanha, e em países iberoamericanos ${ }^{31}$.

De acordo com o manual de TV educativa, do ministério da educação colombiano (2004) a televisão cultural recebe uma denominação mais ampla,

${ }^{29}$ Arlindo Machado - Doutor em Comunicação e Semiótica pela Pontifícia Universidade Católica de São Paulo (PUC-SP). Professor de Pós-graduação em Semiótica (PUC-SP) e professor do Departamento de Cinema, Rádio e Televisão da Universidade de São Paulo (USP). Seu campo de estudos abarca o universo das imagens produzidas por mediações tecnológicas: cinema, fotografia, vídeo, holografia, ciberespaço.

${ }^{30}$ José Bullaude - Professor da Universidade Nacional de Buenos Aires. Mestre em Comunicação pela Universidade de Colômbia. Fotógrafo, cineasta. Coidealizador e criador do Canal 10, de Córdoba, na Argentina, primeiro canal público universitário do país. Foi responsável por parte do desenvolvimento do setor audiovisual argentino. Na década de 60, publicou livros sobre imagem e linguagem audiovisual, mídia e educação. Sua pesquisa e trabalho debruçam-se sobre a arte, fotografia, cinema, design e educação. Idealizou e fundou o lnstituto de Comunicación y Medios Audiovisuales para América Latina.

${ }^{31}$ As televisões educativas e culturais são na maioria dos casos frutos da iniciativa pública, sendo assim em países como Argentina, Brasil Chile, Colômbia, México, Peru, Uruguai e Venezuela. Com exceção da venezuelana Vale TV, tutelada pela igreja católica, e a brasileira TV Futura, pertencente à Fundação Roberto Marinho (TORNERO;VILCHES, 2010). 
incluindo uma diversidade de formatos e audiências muito próximas à televisão comercial, como reportagens, programas de revista, documentários, filmes longa metragem. A televisão comercial é assim classificada por sua programação contar basicamente com entretenimento, objetivando a venda de espaços comerciais em sua programação. A televisão escolar está localizada no centro do sistema de ensino formal, cujo conteúdo corresponde a um currículo escolar e os programas são intencionalmente controlados e instrucionais. Já a televisão educativa desenvolve conteúdos e estratégias específicas expressas através da linguagem televisiva, que geralmente não se encontram explícitos em currículos escolares da educação formal, mas têm suas bases didáticas sustentadas por relevantes teorias de aprendizagem. No documento, entende-se por televisão educativa a composição entre a televisão cultural e a escolar, compartilhando objetivos, estratégias e audiências afins.

Mas este entendimento é criticado por Matilla (2003). O autor percebe que a definição de programas educativos é adotada com grande elasticidade para dar nome a espaços onde não se sabe muito bem o que é priorizado: se o divulgativo, o estritamente escolar ou o amplamente cultural. Para o especialista, tradicionalmente, o conceito de televisão educativa está atrelado à aprendizagem formal.

Matilla propõe então uma definição de TV educativa que começa por conceber uma televisão para a educação de maneira crítica, ajudando a recompor o mosaico de informações fragmentadas, desordenadas e às vezes caóticas da linguagem da televisão convencional. A TV para a educação deve combater à desmemoria, compensar a desinformação e dotar-se de ferramentas para ressignificar a realidade. O propósito então é servir o público com programas que levem formação e conteúdos capazes de relacionar a audiência com o mundo que a cerca.

O especialista legitima a TV como um meio importante de socialização, principalmente, pela capacidade de penetração em várias esferas sociais e pelo amplo alcance do veículo, capaz de ser transmissor de normas, valores e conceitos que competem com os emitidos pela escola e pela família. Apesar das críticas, o autor considera que é inegável a constatação de que a TV serve como acesso a determinados conhecimentos e reconhece que isto é positivo, pois serve de contraste permanente com a escola. 
... porque las horas de inversión de capital humano e intelectual que requiere le suponen un gran esfuerzo a la sociedad, porque ese esfuerzo es pagado de manera más o menos directa por todas las ciudadanas y ciudadanos, porque la escuela está perdiendo la batalla de la educación y necesita más apoyos que nunca, porque existen experiencias emblemáticas que demuestran las inmensas posibilidades del medio, porque la nueva televisión va a permitirnos llevar a la práctica un concepto de educación integral que implica identificar a este medio con otros servicios de valor añadido, incluyendo el acceso a internet, etcétera. (MATILLA, 2003, p. 28)

Matilla (2003) analisa a trajetória deste tipo de emissora por meio de três variedades de programas.

O primeiro deles remete às experiências dos anos 60/70, e é caracterizado por uma intencionalidade educativa, relacionados a um currículo escolar concreto, com objetivos educativos precisos, estruturados e progressivos. São programas escolares, que em muitos casos chegam a certificar o espectador participante, com algum título de reconhecimento oficial. O telecurso exibido na televisão é um destes modelos.

O segundo é formado por experiências de caráter não formal ou informal, que aproveitando formatos e linguagem televisivos, incorporam objetivos educativos. Às vezes servem de apoio à aprendizagem. Visam uma formação mais integral da pessoa, motivando valores positivos ou a mudança de comportamentos e atitudes negativas. Um exemplo deste tipo de programa é Vila Sésamo, e até campanhas educativas como prevenção de acidentes, combate ao tabagismo, etc.

O terceiro e último grupo de programas educativos inclui todos aqueles que não têm uma intencionalidade educativa, mas que exercem influência educativa direta positiva ou negativa. Seguindo este ponto de vista, toda a televisão seria considerada educativa. As novelas, os realitys shows, os telejornais, etc, como espaços aproveitáveis do enfoque educativo.

Nesta concepção de Matilla, a TV educativa tem por obrigação, como serviço público, devolver à sociedade a memória histórica, propiciando a reflexão que muitas vezes não cabe no dia a dia dos outros veículos e imprensa. O autor ressalta que é sabido que a atualidade é identificada, sobretudo, pelo imediatismo, deixando-se de lado a contextualização dos acontecimentos, dos fatos sociais. 


\subsection{2. \\ O papel cultural da TV Educativa}

Este papel cultural e educativo da TV é entendido por Fischer (2001) como um espaço privilegiado de aprendizagens diversas, compreendendo diferenças de gênero, políticas, econômicas, étnicas, sociais, geracionais, percebendo que a TV é simultaneamente linguagem e fato social. A autora chama a atenção para a presença cotidiana da televisão na vida de alunos e professores e reconhece que esta participação ativa no modo de viver dos telespectadores tem repercussões importantes nas práticas escolares, na medida em que jovens, crianças e adultos, de qualquer classe social, aprendem modos de ser e estar no mundo também neste espaço de cultura.

Jesús Martín-Barbero (2002) interpreta o aspecto cultural deste tipo de emissora por outro olhar. Segundo o autor, as tecnologias da comunicação - em especial a TV e, mais ainda, a TV dita educativa e cultural — caracterizam-se por um modo de relacionamento entre processos simbólicos, que constituem o caráter cultural, e as formas de produção e bens e serviços. Ao expor cada cultura às demais, locais ou globais, os atuais processos de comunicação aceleram e intensificam o intercâmbio e a interação entre culturas. E se este modo incorre na possibilidade de ameaça à sobrevivência da diversidade cultural, por outro lado, oportuniza o reconhecimento e a valorização - antes disfarçadas pela folclorização e exotismo do diferente, de manifestações culturais fora aos padrões reconhecidos arbitrariamente como eruditos. Para o autor, o movimento entre culturas envolve transformação/recriação da própria.

Outra prerrogativa da programação cultural na TV, para Martín-Barbero, é mover a arte dos seus lugares próprios, re-situando seu acesso e apreciação dentro do espaço doméstico, ampliando o público e seus usos. A diferença de posição entre os públicos que formam a audiência, nas suas possibilidades e opções culturais, passa agora não pelo acesso real e presencial aos teatros, cinemas, museus, palcos, etc., mas sim, pela quantidade e qualidade dos equipamentos domésticos, televisores. Enquanto que o segmento de maior poder aquisitivo desfruta pela via eletrônica por assinatura da melhor oferta, ampla e especializada, o inverso acontece com os de menor poder econômico cuja variedade e qualidade da oferta decresce a medida que a renda diminuiu. Para o autor, a relação cultural 
na televisão não apenas realoca os lugares e modos de acesso, como também evidencia a separação entre práticas de criação e consumo.

\subsection{3.}

\section{O alto custo da penúria na TV Educativa}

Dentre a todos estes aspectos que conformam a TV educativa, um é especialmente determinante à sobrevivência do seu modelo. Esta especificidade, encontrada em vários países e no Brasil, é sua natureza pública, com variações a respeito da receita, advinda do financiamento público de colaboradores ou do próprio governo local. O modelo de emissora educativa estatal é desenvolvido, mantido e executado pelo Estado, que exerce o controle da emissora. Já o padrão público de radiodifusão é desenvolvido, mantido e executado pela sociedade civil, ou seja, cidadãos, grupos organizados e ONGs.

Este é um fato importante, senão prioritário, da intencionalidade e manutenção deste modelo porque é a partir desta condição que alguns dos pressupostos da comunicação pública a serviço da educação para uma ampla parcela da população - e muitas vezes como política de estado para a escolarização - vai esbarrar em entraves que permanecem há mais de meio século. Dificuldades como receita para contratação de pessoal gabaritado para tais funções; investimento em tecnologia; custos de produção e consequente adequação da mensagem transmitida neste contexto, muitas vezes precários, comprometendo a transmissão e alcance do conteúdo. Outra barreira deste modelo é tornar-se porta voz oficial do estado, incorrendo no risco de má utilização da máquina pública para feitos políticos.

O documento sobre os problemas e potencialidades da televisão educativa, elaborado pelos responsáveis por essas emissoras e profissionais de broadcasting norte-americanos, do Grupo para Televisão, do Serviço de Saúde, Educação e Bem Estar, dos Estados Unidos, ressalta a importância desta condição peculiar da televisão educativa em vigor até os dias de hoje. Fruto destas discussões na década de 60, o documento não perdeu a atualidade dos temas, das condições encontradas e da reflexão a respeito. No texto, os especialistas evidenciam o quanto programas de alta qualidade são dispendiosos. Fazer televisão implica custos altos que, na maior parte dos casos, a televisão educativa não consegue 
arcar. Comparando à televisão comercial, cuja receita vem dos espaços comercializados com publicidade na grade, o orçamento anual de uma emissora educativa é muito inferior ao de um único programa espetacular, comercial.

A receita escassa não explica algumas das questões que serão observadas à frente nesta dissertação, quando analisarmos o estudo de caso. Porém, vale refletir sobre o juízo feito pelo então redator de educação do New York Times, Fred Hechinger $^{32}$, no documento norte-americano sobre TV. Acerca do financiamento público dos governos às emissoras educativas, Hechinger (1970) diz que é sempre imaturo afirmar que a aplicação de verbas governamentais obriga ou não a existência de um controle sobre o conteúdo e gestão destas TVs, afirmando que toda a vez que se aceita recursos financeiros há o perigo de algum controle. Os riscos existem de fato, quando qualquer legislação vincula a dotação financeira a determinadas restrições.

O diretor dos serviços de TV e cinema da universidade de Miami, Sidney $\operatorname{Head}^{33}$ (1970), diz que quando se trata de controle por parte de quem financia, a televisão educativa não estaria em condição tão diferente à TV comercial.

Um dos ingredientes mais importantes dos meios de comunicação pública, do ponto de vista das diretrizes públicas, consiste na exposição de opiniões divergentes sobre assuntos relevantes. Em síntese, a controvérsia. Geralmente se acredita, e não faltam provas disso, que os serviços de televisão comercial, revelam, na melhor das hipóteses, uma natural tendência para evitar controvérsias e, na pior das hipóteses, eliminar essas controvérsias. É compreensível que os anunciantes não desejem ferir suscetibilidades, até mesmo as das pequenas minorias. É compreensível que, sendo seu objetivo alcançar a maioria do público (ou, pelo menos, uma minoria substancial desse público), as opiniões impopulares tendam a ser postas de lado. É compreensível que um meio que constitui um empreendimento comercial privado se incline a refletir a filosofia comercial predominante. [...] Quando voltamos às práticas das emissoras não comerciais, podemos fazer um conjunto de afirmações surpreendentemente paralelas. A TVE também tem suas razões para evitar controvérsias. [...] Se a emissora depender do apoio financeiro da comunidade, deverá ter muita cautela para não afastar seus principais sustentáculos, os quais poderão ironicamente ser representantes dos mesmos interesses do mundo dos negócios, que influenciam as televisão comercial. Se a emissora depender de recursos provenientes de impostos, há de ter muito cuidado para não embaraçar as autoridades eleitas ou os mandatários cujos

${ }^{32}$ Fred M. Hechinger - Editor de educação do The New York Times, autor de vários livros e defensor da educação pública. Foi consultor sênior da Carnegie Corporation de Nova York, entidade filantrópica que promove o avanço e difusão da educação.

${ }^{33}$ Sidney W. Head - Doutor em Comunicação pela Universidade de Nova York. Concebeu os cursos de radiodifusão da Universidade de Miami e Iowa. Foi professor da Universidade de Miami e diretor do serviço de broadcasting da mesma. Presidiu a National Association of Educational Broadcasters (NAEB). Liderou os estudos para o uso da radiodifusão educativa no Sudão, Etiópia, Gana e Somália, na década de 60. 
eleitores possam protestar contra o emprego dos dinheiros públicos na sustentação de pontos de vista com os quais não estejam afinados. (HEAD, 1970, p. 239)

Estas observações são fundamentais, pois leva a refletir se constitui um equívoco presumir que a televisão educativa estaria destinada a compensar amplamente uma debilidade específica da TV comercial.

\subsection{4. Motivação e audiência: nem sempre parceria de sucesso}

Martín-Barbero (2002) assume que a televisão é o espaço onde se manifestam e se replicam comportamentos sociais. $\mathrm{O}$ autor ressalta a condição da televisão pública em educar, tão característica de países da Europa e Ásia, quanto na América Latina e no Brasil. Para ele, a televisão pública tem perfil cultural e dentre as suas expressões está a de tornar-se educadora e formadora da sociedade.

A televisão abre caminho para se tornar alfabetizadora da sociedade toda nas linguagens, habilidades e escritas audiovisuais e informáticas que fazem parte da complexidade cultural específica de hoje, $[. .$.$] a socialização propagada dos novos$ modos de aprender e saber, de ler e escrever, àqueles que estão associados com os novos mapas mentais, profissionais e trabalhistas que se avizinham, e também das novas sensibilidades, estilos de vida, gostos. (MARTÍN-BARBERO, 2002, p.73)

Em sua análise sobre a linguagem textual da televisão, Duarte (2004) coloca que o caráter comercial da televisão, medida via audiência, é determinante para a definição de qualidade e exibição ou não dos produtos na grade. $\mathrm{O}$ teor informativo, cultural, sua função pedagógica e social tornam-se valores secundários. O principal exemplo do que fala a autora seria o horário de exibição dos telecursos nas emissoras comerciais, veiculados justamente quando a maior parte da população ainda dorme. Outro exemplo é o acesso à programação de qualidade das televisões educativas de caráter privado, privilégio restrito a seus assinantes.

É que aqui são as tevês comerciais que dão as cartas: elas imprimem o tom, o teor informativo e a qualidade dos produtos televisivos, depois perseguidos por tevês estatais e públicas, essas sim enfraquecidas, empobrecidas, carentes do ponto de vista de recursos humanos e técnicos, desaparelhadas do ponto de vista tecnológico e sempre comprometidas com questões políticas e ideológicas. (DUARTE, 2004, p. 17)

Custos e consequentes linhas editoriais são espelhados, invariavelmente, no conteúdo exibido, muitas vezes embalado em gêneros e formatos mais simples e baratos ao orçamento e ofertado à audiência. 
Meyer $^{34}$ (1997) explica que a televisão é um meio caro demais para ser usado na educação de pequenos grupos da população. O autor é enfático em dizer que oferecer este tipo de oferta num meio tão abrangente é um equívoco. E se pergunta: programas educativos são realmente o que o público deseja? Quem quer mais este tipo de coisa? A "coisa" a qual se refere são os programas classificados como educativos e culturais, engessados nesta denominação. A interpretação a princípio severa, explicitada durante simpósio internacional sobre programação educativa $^{35}$, em 1996, na Alemanha, tem por pano de fundo um problema concreto deste tipo de programação, reconhecido mundialmente: a baixa audiência.

Este aspecto desfavorável, segundo Meyer, é consequência da interpretação confusa do meio e da própria concepção de educar pela TV pelos produtores deste tipo de televisão. De acordo com o autor, a questão central não está no que as pessoas aprendem pela televisão ou se elas não aprendem nada, mas se elas encontram uma programação interessante e que as faz permanecer e assistir. $\mathrm{O}$ especialista considera válido o propósito pedagógico, desde que o programa seja atraente e não apregoe a intenção didática, fazendo o espectador sentir-se que é esperada dela algum tipo de aprendizagem. Meyer é veemente, para ele este tipo de empenho causa rejeição na audiência e zapping para outro canal. O autor acredita que a televisão educativa deve considerar e desfrutar da característica essencial do meio: o entretenimento. Para ele, se os programas educativos incorporarem mais o entretenimento e a linguagem da TV, contribuirão, então, melhor para tornar a compreensão possível pela audiência.

Aqui, toma-se por definição de $\operatorname{Orozco}^{36}$ (2001), audiência como o conjunto segmentado a partir de suas interações midiáticas de sujeitos sociais, ativos e

34 Manfred Meyer - Diretor do Internationales Zentralinstitut für das Jugend- und Bildungsfernsehen (IZI), o centro de informação e documentação da Bavarian Broadcasting Corporation, desde 1965. O IZI contribui para a compreensão do significado cultural da televisão para crianças e jovens, investigando como a televisão está inserida no cotidiano dessas crianças e jovens. A pesquisa também se debruça sobre a missão das TVs públicas e a responsabilidade social dos meios de comunicação em geral.

${ }^{35}$ Educational Television - What do people want? Internationales Zentralinstitut für das Jugendund Bildungsfernsehen (IZI), Munich. 1997.

${ }^{36}$ Guillermo Orozco Gómez - Doutor em educação pela Universidade de Harvard. Catedrático em Ciências da Comunicação na Universidad de Guadalajara. Coordenador do grupo de trabalho sobre estudos de recepção da ALAIC e catedrático UNESCO. Pesquisador dos processos de recepção e do campo comunicação e educação. 
interativos, que não deixam de ser o que são enquanto envolvidos numa relação sempre situada com o referente midiático, seja esta direta ou indireta.

Evidente que a concepção mais humanizada e nada numérica de Orozco de audiência, passa ao largo do ponto de vista das emissoras assumidamente comerciais. Para este segmento, quando o público é o maior número possível de espectadores, o entretenimento é a principal oferta à audiência, reduzida a relação de consumo. Enquanto que o interesse público e promoção da cidadania são tônicas do discurso das televisões educativas.

Porém, Lasswell (1970), explica que interesse público depende da disposição do espectador. Programas que versam sobre interesse público são construídos com base numa estrutura de conhecimentos de um público comum, onde é possível acrescentar detalhes informativos e interpretativos, de forma cumulativa. A formação do público significa que uma determinada camada da comunidade está preparada para assistir a programas específicos, em dados horários, afastando-se quando não houver interesse. E para quem produz televisão educativa, o público é aquele que vai à escola, havendo um esforço para oferecer aprendizagem que unam pais e filhos diante da tela, seja num programa sobre curiosidades científicas, línguas ou mesmo programas musicais. Uma programação concebida como erudita para um público dito culto, contemplado pelo efeito cumulativo da televisão educativa. Esta imagem geralmente concebida pelo senso comum é notada por Lasswell:

Conforme certa noção estereotipada, quem transmite um programa comercial é pessoa capaz de vender a própria mãe para obter um anúncio, ao passo que o responsável por uma transmissão educativa, trata-se também de um clichê, é um indivíduo que mata o público de tédio para o bem deste mesmo público. Os dois estereótipos possuem o seu fundo de verdade, do contrário não teriam a menor força. $\mathrm{O}$ supremo valor procurado por quem leva ao ar um programa educativo consiste no respeito profissional pela capacidade de educar e esclarecer. A estrutura institucional da indústria é de tal natureza que se ela não se esforçar por auferir lucro em benefício dos seus acionistas estará na realidade transgredindo uma obrigação legal. A estrutura institucional da televisão educativa, ao contrário, é construída pela ausência da intenção de lucro pelo seu caráter profissional. Ela é legal e moralmente obrigada a servir de maneira direta ao bem comum $^{37}$. (LASSWELL, 1970, p. 189)

\footnotetext{
${ }^{37}$ Lasswell define bem comum como uma regra que reforça e valoriza a posição de todos os membros da sociedade de maneira imparcial, ao invés de privilegiar algumas classes. Segundo o autor, governos que têm em conta o interesse comum são constituídos de acordo com rigorosos princípios de justiça, em oposição àqueles que consideram apenas os interesses dos governantes, considerado um governo pervertido, despótico, uma vez que negligencia que o estado é uma comunidade de homens livres (LASSWELL; KAPLAN, 1950, p. 231).
} 


\subsection{5. \\ Educação e cultura na TV atual}

O entendimento de que televisão é um dispositivo educativo e cultural — reconhecendo a televisão educativa como agente de transformação social — levou à atual categorização deste tipo de emissora como televisão educativa e cultural já adotada por diversos países ${ }^{38}$.

Fläckel ${ }^{39}(2008)$, em sua pesquisa sobre televisão educativa, entrevistou vários produtores de 26 emissoras educativas, de 20 países, incluindo o Brasil. $\mathrm{O}$ estudo trouxe dados recentes que ajudam a solidificar o cenário mundial atual deste tipo de emissora. Perguntados sobre o que é televisão educativa, um grupo afirmou que não é escola. As respostas demonstraram que a maioria não transmite intencionalmente conteúdo curricular escolar formal, sugerindo que a informação veiculada neste tipo de emissora pode até gerar efeitos de educação, mas deve ser construída com linguagem mais próxima dos telespectadores, associando conteúdo e entretenimento. Contudo, a pesquisa aponta que existe sim um planejamento educativo, que visa a motivar o conhecimento e que os usos e propósitos deste tipo de emissora vão variar de acordo com as necessidades educativas de cada país, servindo como mediador em processos de alfabetização, educação de adultos, etc. O efeito educativo vai depender da reação do telespectador, de como ele reagirá à informação. Aí está um impasse que perdura até os dias atuais e pode sugerir que a resistência ao entretenimento, enquanto condição de prazer à aprendizagem, é fruto de uma angústia sobre o próprio papel da escola na sociedade.

\footnotetext{
${ }^{38}$ No Brasil, os termos pública, educativa e cultural se confundem na área de audiovisual. A legislação se utiliza apenas da designação televisão educativa em contraposição à televisão comercial. Os três principais documentos que regram a outorga de rádios e TVs educativas são o Decreto-Lei 236, de 28 de fevereiro de 1967, o Decreto ${ }^{\circ} 2.108$, de 24 de dezembro de 1996, e a Portaria Interministerial $n^{\circ} 651$, de 15 de abril de 1999. Neste último é possível notar a ubiquidade da televisão educativa, ou seja, sua capacidade de ser/estar em diferentes campos sociais e propósitos, tais como o escolar, cultural, educativo, instrutivo e até mesmo desportivo. O texto estabelece que a radiodifusão educativa é o serviço de radiodifusão sonora (rádio) ou de sons e imagens (TV) destinado à transmissão de programas educativo-culturais, que, além de atuar em conjunto com os sistemas de ensino de qualquer nível ou modalidade, vise à educação básica e superior, à educação permanente e à formação para o trabalho, além de abranger as atividades de divulgação educacional, cultural, pedagógica e de orientação profissional.

${ }^{39}$ Andreas Fläckel - Mestre em Filosofia, com o estudo de caso internacional "Bildungsfernsehen als Teil des Public Value? Die kommunikatorenseitige Verortung eines Genres. Eine internationale Studie, pela Faculdade de Ciências Sociais, da Universidade de Viena.
} 
Tal questão vem sendo debatida desde a década de 1960 por Hechinger (1970), que alega existir uma sutil linha divisória entre aprendizagem e entretenimento na TV por conta do papel que ela tradicionalmente desempenha nos lares. O apelo é geralmente dirigido ao repouso, sendo raro tornar-se puramente educativo, salvo se impuser algumas exigências. $\mathrm{O}$ grau de educação e aprendizagem que ela proporciona encontra-se na mente do espectador, dependendo da condição histórico-social deste. E tais exigências podem ser implícitas ou de caráter obrigatório, como cursos que conferem créditos ou certificados à audiência.

Essa impressão, de que tudo o que se refere à escola é rígido em excesso e não há espaço para a ludicidade, é relatado por Seldes ${ }^{40}$ (1970). O autor explica que o preconceito contra a escola e o ensino significa ruído entre a TV educativa e os que recebem seus programas. E claro, se ainda ocorre dentro da própria TV entre quem faz o produto, o que caberá à audiência?

O conceito do educador como inimigo da sociedade é um tanto mais recente. Uma das ideias mais poderosas ou mais arraigadas se associa a uma série de clichês: o aluno querido do professor, o menino-prodígio, o fraquinho de físico, o estudante que se mata em cima dos livros na escola superior, e o pedante, no final desse processo. Enquanto a TVE continuar seguindo avante em outros setores, poderá acelerar sua influência em solapar e destruir essa série de imagens. (SELDES, 1970, p.208)

Braum et $a l^{41}$ (1970) explica que televisão tem a capacidade de mudar a relação de ensino, principalmente na sala de aula. Em especial, no sentido de libertar este professor para que ele possa empregar de maneira mais produtiva seu tempo e ação com os alunos. O autor esclarece que a televisão é capaz de oferecer o detalhe, o verossímil in loco ou diversos pontos de vista para toda a turma ao mesmo tempo, facultando aos alunos acompanhar as atividades, que seriam postas a perder se fossem objeto da observação direta, presencial. Entretanto, ressalva, há coisas que a televisão não poderá fazer, como orientar de maneira eficiente um debate ou seminário. A TV é incapaz de proporcionar ajuda pessoal, específica e direta. Isto cabe ao professor.

\footnotetext{
${ }^{40}$ Gilbert Seldes - Jornalista, escritor e crítico cultural. Autor de adaptações de clássicos literários para a Broadway, como Sonhos de Uma Noite de Verão, nos anos de 1930. Escreveu diversos roteiros de filmes históricos documentais; roteiros de rádio, e se tornou o primeiro diretor de televisão da CBS e reitor fundador da Escola Annenberg de Comunicação, na Universidade da Pensilvânia.

${ }^{41}$ Cyril M. Braum - Engenheiro de broadcast da Radio Corporation of America, RCA. Consultor do Centro Nacional de Educação e Rádio.
} 
Outra peculiaridade da TV educativa - e que vai emergir nos resultados desta pesquisa de campo com os produtores da MultiRio - é que este tipo de emissora requer mão de obra especializada.

Para Braum et al (1970) é essencial haver pessoal competente e criativo o suficiente para tornar os produtos tão atrativos quanto os exibidos pela TV comercial. As emissoras educativas devem possuir em seus quadros pessoal familiarizado com os conteúdos educativo e cultural. Comunicadores que não entendem de educação e educadores que não dominam a linguagem dos meios de comunicação constituem ponto crítico deste tipo de produção. A inexistência deste corpo de profissionais qualificados gera ruído no conteúdo, na mensagem transmitida, por falta de compreensão de ambas as partes e, certamente, atritos nos bastidores.

Hall $^{42}$ (1970) considera que este tipo de conflito pode ter origens no processo de formação do professor. É necessário que as escolas de formação de professores incluam em seus currículos disciplinas que versem sobre métodos e técnicas de ensino pela televisão ${ }^{43}$. Segundo o autor, é uma especialização e uma necessidade que deve ser compreendida com urgência, segundo o autor. Seldes (1970) corrobora a opinião de Hall e soma às atribuições da TV educativa a formação de professores peritos em comunicação:

Deveria ser finalidade específica da TVE assegurar que o emprego da televisão nas escolas e faculdades seja ensinado como parte da formação dos professores, e que um número crescente de professores aprenda a utilizar-se da televisão, não só na qualidade de docentes que permanecem nas salas de aula e assistem aos programas de televisão com seus alunos, mas como mestres que ensinam através da televisão e, se possível, como produtores de programas. (SELDES, 1970, p.220)

O embate constatado há décadas neste tipo de emissora é descrito por Head (1970) como lamentável, pois impede a TV educativa de avançar na mesma velocidade da TV comercial quanto à linguagem, formatos e, principalmente,

42 Joe Hall - Professor. Superintendente escolar do governo de Miami para educação infantil. Durante a década de 1960, foi responsável pela acolhida e educação pública de refugiados cubanos. Hall esteve à frente da ampla utilização da televisão no campo do ensino na cidade.

${ }^{43}$ Hoje, ou seja, 40 anos depois do que foi dito por Hall (1970), vale ressaltar que apesar da sugerida importância deste tipo de conteúdo veiculado pela TV, a ausência de disciplina específica para produção em educação é notada nos atuais currículos dos 12 cursos de graduação das faculdades públicas e privadas de Comunicação Social, habilitação Jornalismo, no município do Rio de Janeiro, conforme grades curriculares exibidas nos sites das instituições e ratificadas por seus respectivos departamentos. Condição diferente da encontrada em 17 cursos de Pedagogia no mesmo município. Disciplinas de mídia e educação compõem a grade curricular de seis cursos. E maioria conta com matérias relativas à informática educativa e EAD no currículo, privilegiando mídias digitais. 
experimentações. É propensão da TV educativa, particularmente, quando este tipo de TV tem relação direta com o estado ou é patrocinada por órgãos escolares.

Também a observamos na tendência para erigir-se em mística o ensino pela televisão como forma de comunicação dotada de características sem paralelo, que situam a televisão a serviço do ensino em posição à parte das demais formas de produção através da televisão. Vemo-lo nas rivalidades entre o pessoal orientado no sentido da televisão, e o orientado no sentido da educação. (HEAD, 1970, p.238)

Em quase meio século de discussão, Hartford Gunn ${ }^{44}$ (1970) já sinalizava que os cursos de comunicação também negligenciam a formação em educação. Os autores alegam que a TV educativa carece de profissionais híbridos. São os profissionais envolvidos no processo os responsáveis pelo êxito ou fracasso da programação educativa. E os cursos de formação em comunicação tem sua parcela de culpa quando omite o preparo de pessoal para a televisão educativa ou proporciona esse preparo de maneira precária.

Todas estas questões aparentemente não chegam ao telespectador, porque justamente não se faz habitualmente o que Kaplún $(1998,1999)$ sugere: construir o conteúdo com sua audiência, participar a todos os atores do processo de educação pela TV esta discussão e consequente geração de conteúdo. De onde se concluiu que a discussão sobre televisão educativa é ampla e repleta de nuances e a orientação feita por Seldes (1970), há 40 anos, é ainda pertinente: é preciso que a TV educativa olhe para si mesma, faça uma autocrítica, na tentativa de se corrigir. Reconhecer a necessidade de interpretar o que é corrente nas práticas educacionais, compreender e aceitar mudanças que se verificam. Isto obriga a TV educativa a interpretar suas próprias funções. E aos estudiosos do setor colaborar com esta reflexão.

Diante deste cenário de tantas propriedades e responsabilidades, incertezas e pluralidade de definições, como educar pela TV? A tentativa de responder a esta questão vai embasar-se nos princípios de Mario Kaplún para uma comunicação educativa.

\footnotetext{
${ }^{44}$ Hartford N. Gunn Jr - Pioneiro na televisão educativa e presidente-fundador do Serviço Público de Radiodifusão dos EUA, a PBS, em 1970, com 110 estações à época.
} 


\section{2.}

"Uma pedagogia para a comunicação"

Mario Kaplún defende um encontro transformador e dialógico entre comunicação e educação. Transformador no sentido de provocar mudanças sociais objetivando a promoção da cidadania. Dialógico porque ambas as áreas constroem juntas o discurso comunicado, baseado na interação entre audiência e comunicadores na produção de conteúdo. Segundo Kaplún, o processo educativo é concebido substancialmente numa proposta coletiva. O teórico, professor e radialista argentino desenvolveu seus estudos e práticas no rádio alicerçado nas ideias e metodologias de Paulo Freire, com seu sistema de educação libertadora, e no princípio de conhecimento como uma construção social, elaborado por Célestin Freinet.

O termo educomunicador é atribuído a sua criação, pois aparece diversas vezes na publicação, Una Pedagogia de la comunicacion (1998, p.88 e outras). A obra apresenta as variações de metodologias de ensino geralmente empregadas nas escolas e reproduzidas nos meios de comunicação educativos. No texto, Kaplún apresenta sugestões para uma comunicação educativa bem sucedida, fundada numa educação libertadora e transformadora. Conforme descreve, o educomunicador é o comunicador ou educador cuja missão é elaborar e dar forma as mensagens, formulando o conteúdo pedagogicamente.

A expressão não chega a ser mencionada em seu texto anterior, El comunicador popular (1985). Todavia, na publicação, Kaplún descreve este tipo de profissional, considerando que este exalta os valores da comunidade, a solidariedade, a cooperação, a criatividade, a coragem e capacidade potencial de cada indivíduo. O autor chama este personagem de facilitador (1985, p.59). E ratifica que o papel deste é problematizar o conteúdo e estimular o debate, o diálogo, a reflexão e a participação, promovendo a conscientização da audiência (ou do aluno) de sua própria dignidade, de seu próprio valor como pessoa. $\mathrm{O}$ objetivo, como o autor enfatiza, é fazer com que o sujeito pense.

La información, pues, es necesaria. Un dato, un aspecto de la realidad, puede ser indispensable para que el grupo avance. Y el educador (o el comunicador) no debe dejar de aportarlo. Pero esa información debe responder a una previa problematización: a una necesidad que el grupo siente, a unas preguntas que éste se formula, a una búsqueda, a una inquietud. Si esa inquietud no nace en el grupo y el educador juzga que esa información es imprescindible para que los educandos puedan avanzar en su proceso, su primera tarea será despertar esa inquietud, hacer 
que esas preguntas surjan: vale decir, problematizar. Sólo entonces aportará la información. Porque sólo así el grupo la incorporará, la hará suya. (KAPLÚN, 1985, p. 57)

Os argumentos e pressupostos de Kaplún puderam ser desenvolvidos e aperfeiçoados em sua práxis em educação e comunicação com a televisão e, notavelmente, com o rádio. Kaplún é um teórico que valoriza a prática. Por isto, sua contribuição é fundamental para esta análise, pois é para a prática, para o como vem sendo desenvolvido conteúdo educativo em televisão que interessa a esta pesquisa. Para esta dissertação, suas inferências - descritas em seus roteiros para a produção radiofônica educativa - constituirão um guia para a análise dos dados coletados durante o estudo de caso.

Com base nos estudos de Juan Díaz Bordenave ${ }^{45}$, Kaplún explica que existem três tipos primários de educação, divididos em dois modelos: Exógeno e Endógeno.

No Modelo Exógeno, encontram-se dois tipos de educação. O primeiro, cuja ênfase está nos conteúdos; e o segundo, cuja prioridade são os efeitos. O tipo que põe ênfase nos conteúdos corresponde à educação tradicional, baseada na transmissão de conhecimento e valores entre gerações, professores e alunos, entre a elite "instruída" e a massa "ignorante". Já o que privilegia os efeitos corresponde à chamada "engenharia do comportamento" tencionando fundamentalmente moldar a conduta das pessoas com objetivos previamente estabelecidos. Nestes dois padrões, o educando é visto como objeto da educação, ou seja, como uma massa amorfa que precisa ser moldada pelo professor, transferindo os conhecimentos para os alunos.

Contrário a estes, o Modelo Endógeno, adotado e defendido pelo autor, contempla o padrão de educação que privilegia o processo. "En efecto, todo proceso educativo es un proceso de comunicación" (KAPLÚN, 1985, p. 9). O Modelo Endógeno ressalta a importância da transformação do sujeito e da comunidade. Aqui, a preocupação não é tanto com os conteúdos que serão comunicados nem com os efeitos ao término da exposição. Neste tipo de educação, o importante é a interação dialética entre as pessoas e a realidade

\footnotetext{
${ }^{45}$ Juan Enrique Díaz Bordenave - Pedagogo, educador e comunicador. Doutor em Comunicação pela Universidade de Michigan. Precursor do pensamento educomunicacional latino-americano, junto com Mario Kaplun e Paulo Freire.
} 
destas; o desenvolvimento de suas capacidades intelectuais e de sua consciência social.

Dentro deste contexto, o professor é aluno e o aluno, professor. Nada se educada sozinho, as pessoas se educam entre si mediadas pelo mundo. É este movimento, esta troca, que o autor considera "o processo educativo". Desta forma, o professor tem o papel de estimular o aluno, de facilitar a busca pelo conhecimento, problematizando, fazendo perguntas e ouvindo, ajudando o grupo a se expressar. A educação é coletiva, privilegiando a cooperação, a criatividade e a capacidade potencial do todo indivíduo.

Este é o modelo empregado por Kaplún na produção de educação através dos meios.

Para o autor radialista, o rádio tem uma função social a cumprir, uma contribuição a dar diante às urgentes necessidades das massas populares. A experiência de Kaplún empresta à televisão — em especial à TV educativa — os progressos e êxito do autor no propósito de educar através da mídia, trazendo para a análise desta dissertação uma contribuição sólida.

Kaplún fala de rádio, mas o parecer poderia ser dado também à produção televisiva. $\mathrm{O}$ especialista é enfático e atesta que estamos habituados à perspectiva de que programas educativos são chatos e áridos. Sabemos que nos fazem bem, mas não nos motivam. Para ele, radiodifusão educativa costuma provocar a imagem de um professor solitário diante do microfone, ensinando com voz e tom professoral a um aluno invisível de uma escola tradicional.

O mesmo ocorre com a noção de espaço cultural, segundo o autor. Geralmente, entende-se por um programa deste gênero algo totalmente à parte da realidade da maioria das pessoas. De acordo com Kaplún, a causa está na concepção desfavorável e equivocada de que o cultural é contrário ao popular e a cultura um produto para as elites, seleto, refinado e até um pouco supérfluo, se aproximando muito mais facilmente do museu do que a vida cotidiana.

En consonancia con esos contenidos, el locutor, al iniciar ese espacio, hará un deliberado esfuerzo por diferenciarlo del resto de la transmisión, adoptando un engolado tono formal y solemne. (KAPLÚN, 1999, p. 21)

O teórico afirma que um programa educativo não tem porque ser aborrecido ou esnobe. E não deve sê-lo. Kaplún defende que os programas culturais podem e devem alcançar, atrair e servir a população. Do mesmo modo, que os programas 
ditos de entretenimento não têm que ser superficiais, podendo ser veículos ricos em estímulos educativos e culturais. Na sua percepção, os meios de comunicação cumprem as funções de informar, educar e entreter. Todavia, estas atribuições não ocorrem separadamente. Daí, constitui um equívoco separar estas competências em categorias de programas: informativo, educativo-cultural e entretenimento.

Para o autor, não há comunicação educativa sem considerar o ambiente em que esta ocorre. Kaplún argumenta que a cultura, as relações sócio-históricas que ocorrem neste ambiente é fundamental para motivar e assegurar a aprendizagem. Segundo o teórico, cultura não é uma mera acumulação de conhecimentos em separado da vida. Cultura, no entendimento do autor, é consciência para compreender melhor o próprio mundo. Por conseguinte, Kaplún vai ampliar a concepção de educação radiofônica a partir do ponto de vista social e cultural.

Seguindo esta premissa, não são apenas as transmissões especializadas sobre alfabetização ou educação básica que servem ao processo educativo, cuja utilidade e necessidade são inquestionáveis. Para Kaplún, são fundamentais também aquelas que procuram transmitir valores, a melhoria humana, o desenvolvimento integral do homem e da comunidade, que se propõem elevar o nível de consciência e reflexão, convertendo cada sujeito em agente ativo da transformação do seu meio natural, econômico e social.

Valendo-se então do Modelo Endógeno de educação, Kaplún propõe que o processo de produção de programas educativos e sua intencionalidade sejam revistos e fundamentados numa educação para a democracia, promovendo a transformação da sociedade. Já não se trata de uma educação para informar, mas sim formar as pessoas e levá-las a transformar sua realidade.

Transpondo para os meios, neste modelo, a comunicação é democrática. Ela deixa de ser um monólogo do emissor para o receptor e passa a ser um diálogo. Não concentra o poder de enunciar. A enunciação é coletiva e participativa. $\mathrm{O}$ discurso é horizontal e está a serviço das maiorias, permitindo que a audiência compreenda criticamente a realidade que a cerca.

Kaplún considera que, na prática, é impossível que toda a comunidade participe pessoalmente da produção de programas ou outras formas de comunicação. Com isto, é preciso compor uma equipe responsável pela produção. Mas como seriam estes produtores? Para ele, esta equipe é criativa e, no lugar de sentir-se emissora exclusiva e privilegiada, coloca-se como facilitadora e 
organizadora da comunicação, encontrado formas e caminhos para que os meios gerem um diálogo cada vez mais compartilhado e gradualmente se abram a participação dos seus destinatários.

La función del comunicador en un proceso así concebido ya no es la que tradicionalmente se entiende por fuente emisora. Ya no consiste en transmitir sólo sus propias ideas. Su principal cometido es el de recoger las experiencias de los destinatarios, seleccionarlas, ordenarlas y organizarlas y, así estructuradas, devolvérselas, de tal modo que ellos puedan hacerlas conscientes, analizarlas y reflexionarlas.

Cuando el mensaje es difundido, el sujeto colectivo puede reconocerse en él, identificarse con él, aun cuando no haya participado directamente en su producción; aunque sean otros actores y no él mismo lo que está sobre el escenario dando vida a la historia. Él es de alguna manera coautor del mensaje; comienza a hacerse emirec ${ }^{46}$.

Pero no sólo se trata de reflejar a la comunidad (o a la región, o a la organización) como un espejo que devuelve una imagen o como un grabador que repite y reproduce mecánicamente lo que la gente dice. El equipo comunicador debe procurar devolver esos hechos y experiencias que ha recogido, de tal manera que ahora la comunidad pueda verlos con otra perspectiva crítica, analizarlos, discutirlos, reflexionarlos, emitir un juicio, desentrañar las causas del problema que hasta ahora habían estado viviendo y sufriendo como una mera contingencia, sin percibir sus raíces. Nuestra manera de presentar los hechos debe ser problematizadora, suscitar la reflexión. Es a esto a lo que llamamos formulación pedagógica del mensaje. (KAPLÚN, 1998, p.67)

A partir destes argumentos propostos por Kaplún para uma comunicação educativa eficaz será examinado o processo de produção do estudo de caso elegido para esta dissertação, uma vez que o autor se aproxima do universo da radiodifusão por meio da experiência prática com objetivo educativo.

Ademais, este híbrido entre as duas áreas de conhecimento mostrou-se parco no universo de pesquisas levantado para fomentar esta dissertação, mesmo considerando as duas áreas de conhecimento: educação e comunicação, como foi possível notar no levantamento bibliográfico.

\section{3.}

Abrindo a grande angular: o levantamento bibliográfico

Para o levantamento bibliográfico foram escolhidas as seguintes palavraschave: mídia, educação, TV, programação educativa, comunicação e suas

\footnotetext{
${ }^{46}$ Kaplún utiliza-se do termo cunhado por Jean Cloutier, em 1973, no capítulo L'ère d'Emerec ou la communication audio-scripto-visuelle à l'heure des self-média, do livro Le Petit traité de communication (Presses de l'Université de Montréa). Jean Cloutier amalgamou as palavras Emissor e Receptor para expressar que o processo de comunicação deve realizar-se de modo a dar a todos a oportunidade de ser, alternativamente, emissores e receptores. Não mais emissores e receptores ou locutores e ouvintes, e sim interlocutores.
} 
respectivas traduções para as línguas inglesa e espanhola: media, education, television, educational programming/ broadcasting, communication e medios, educación, televisión, programación educativa, comunicación. A opção por estas palavras justifica-se por acreditar que as mesmas abrangem os sentidos e conceitos necessários para o estudo proposto.

O primeiro passo do levantamento foi identificar os grupos de pesquisa que estudam educação e comunicação na Anped e na Intercom $^{47}$. Ambas possuem grupos específicos que tratam destas áreas de saberes e suas convergências. Contudo, o campo de conhecimento comunicação foi verificado também em alguns poucos trabalhos em grupos de estudos de áreas correlatas como filosofia da educação e sociologia da educação, versando quase sempre sobre indústria cultural e pensamento crítico e representações simbólicas e sociais. O mesmo se verifica quanto à educação em outros grupos de pesquisa de áreas afins contempladas na Intercom.

As duas entidades possuem sites de acordo com a edição anual do encontro e não um portal com sistema de busca por palavras-chave, o que faz com que seja necessário verificar a programação de cada ano, considerando como critério utilizado como seleção preliminar na busca o título do trabalho apresentado nos grupos e posterior leitura do resumo ou íntegra do artigo apresentado.

$\mathrm{Na}$ Anped, foram verificados os GTs:

a) GT 16 - Educação e Comunicação,

b) GT 14 - Sociologia da Educação,

c) GT 17 -Filosofia da Educação.

$\mathrm{Na}$ Intercom, foram analisados os DTs :

a) DT 6 Interfaces Comunicacionais - GP Comunicação e Educação,

b) DT 4 Comunicação Audiovisual - GP Televisão e Vídeo,

c) DT 7 Comunicação, Espaço e Cidadania - GP Mídia, Culturas e Tecnologias Digitais na América Latina.

Foram pesquisados 1.030 trabalhos apresentados nos grupos de pesquisa acima descritos na Anped e Intercom, no período entre 2008 e 2013. Destes, 37

\footnotetext{
47 Anped - Associação Nacional de Pós-Graduação e Pesquisa em Educação. Intercom - A Sociedade Brasileira de Estudos Interdisciplinares da Comunicação. GT, sigla para Grupos de Trabalho da Anped. DT, sigla para Divisões Temáticas dos Núcleos de Pesquisas da Intercom
} 
foram selecionados como leituras tangentes e/ou diretamente relacionadas ao tema TV Educativa e modos de produção em programação educativa.

Através do levantamento realizado pelos títulos dos trabalhos selecionados e respectiva leitura dos mesmos, pode-se supor a insuficiência de pesquisas apresentadas nestes grupos que verificam a produção de programação educativa para TV, observando os sujeitos produtores deste tipo de programação e comunicação com finalidade educativo-pedagógica.

A busca por artigos em revistas acadêmicas específicas foi feita com as palavras-chaves na base de dados do Portal Periódicos Capes, na busca por "Assunto". Para a chave "mídia educação" foram observados 394 resultados. Para a chave "TV educativa" foram verificados 317 resultados. E ainda que o recorte temporal tenha sido determinado entre os anos de 2008 e 2013, foram encontrados cinco artigos publicados em 2005 pela revista Comunicar que dialogam diretamente com o tema TV Educativa e modos de produção em programação educativa. O critério de seleção para a consulta em periódicos seguiu a qualificação dada pela Capes (Qualis) como A1, ou seja, o mais elevado. Ainda neste levantamento foram encontrados um artigo na Revista Famecos e um artigo na Revista Educação \& Sociedade que atendem de forma transversal ao tema de estudo.

Vale acrescentar a pesquisa feita a partir da leitura de bibliografia específica a respeito da criação das TVE e Rádio MEC, publicada pela própria TV Educativa (MILANEZ, 2007). Durante a leitura sobre a participação da UNESCO no processo de criação destas emissoras, recorri à base de dados da UNESCO, disponível no site da instituição. A Organização das Nações Unidas para a Educação, a Ciência e a Cultura possui vasto acervo de artigos, publicações e documentos disponíveis para consulta, download e compra.

Do acervo da UNESCO foi possível, através do uso das palavras-chave, selecionar a edição especial da revista publicada pela UNESCO, El Correo, cujo título La televison, oportunidad y problema educativo, ano de 1953 trata da criação e trajetória da $\mathrm{BBC}$, emissora referência para criação e modelo de TVs Educativas, inclusive Brasil. Assunto pelo qual transversa o tema TV Educativa e modos de produção em programação educativa proposto para estudo. Além da publicação Indicadores de qualidade nas emissoras públicas - uma avaliação contemporânea, do ano de 2012, que também interessa como estudo para o tema. 
O Banco de Teses do portal Capes permaneceu por quase um ano, em 2013, fora do ar sob a alegação institucional de criação de nova versão do site de busca, atualizada e modernizada, inviabilizando a pesquisa por trabalhos no portal. Desta forma, foi realizado levantamento na Biblioteca Digital Brasileira de Teses e Dissertações, do Instituto Brasileiro de Informação em Ciência e Tecnologia, o Ibict. A pesquisa foi feita a partir das palavras-chave. O critério utilizado também seguiu a seleção preliminar pelo título e posterior leitura do resumo das teses e dissertações.

Utilizando a chave "TV educativa" na base BDTD, foram observados 57 resultados. Destes, três foram selecionados de acordo com o diálogo com o tema do projeto. Para a chave "jornalismo educativo" foram encontrados 18 resultados, sendo um selecionado. Utilizando o termo "mídia educação" foram observados 595 resultados, cinco selecionados. Para a chave "programação educativa", 46 resultados foram apresentados, dois selecionados. Dentre as 69 respostas para o termo "jornalista educação", dois foram escolhidos. Alguns destes mesmos resultados são obtidos utilizando mais de uma keyword.

Consultando a base de dados da PUC-Rio, tendo o tema TV educativa e modos de produção em programação educativa, foi encontrada a dissertação $\mathrm{O}$ que os professores acham que aprendem com a televisão, de Cíntia Nascimento de Oliveira Conceição, de 2010.

Desta revisão de literatura, pode-se concluir que há maior correspondência do tema proposto para o estudo na área de comunicação social que na área de educação. Os resultados também sugerem a preferência em pesquisas tanto na área educação quanto comunicação por outros meios, como por exemplo, as mídias digitais, para as quais, para efeito comparativo, foi feita uma busca no BDTD com a palavra-chave "novas tecnologias educação", obtendo — somente com esta chave, 1434 incidências.

Fundamentado nestes resultados, julgou-se necessário ir a campo investigar a produção televisiva educativa, considerando a perspectiva da educação como forma de compreender o fenômeno e contribuir para o debate a respeito. 


\section{4. \\ MultiRio, um estudo de caso}

Em 1993, a prefeitura do Rio de Janeiro criou a Empresa Municipal de Multimeios, a MultiRio, vinculada diretamente à Secretaria Municipal de Educação. O objetivo da empresa é a promoção de ações educativas através da geração, produção e difusão de dados, sons e imagens, exibidos em plataformas como televisão, rádio, internet e impressos.

Entre as atribuições da instituição, estão produzir, coproduzir, adquirir e vender programas de natureza educativa para veiculação em multimeios que promovam, apoiem ou interajam com os sistemas de educação formal e não formal; pesquisar, desenvolver e aprimorar recursos didáticos que envolvam novas tecnologias; desenvolver e executar projetos de produção de recursos de ponta para órgãos da administração direta, indireta, municipal, estadual e federal. A MultiRio ainda colabora, por meio de seus produtos, com a atualização e capacitação de professores da rede pública municipal ${ }^{48}$. Conforme documentação da empresa ${ }^{49}$, elegeu-se como público alvo prioritário professores e alunos do $6^{\circ}$ ao $9^{\circ}$ anos do ensino fundamental. A opção prioritária tecnológica recaiu sobre a televisão, considerando a presença do meio no cotidiano dos estudantes e suas potencialidades educativas e de reforço no trabalho de professores e alunos.

A Secretaria Municipal de Educação do Rio de Janeiro com mais de 1.400 unidades escolares, entre educação infantil e escolas do ensino fundamental, sendo responsável pela maior rede pública de ensino da América Latina.

A demanda constante de suporte à política pública da Secretaria Municipal de Educação e o reconhecimento dos professores da rede na capacidade técnica e pedagógica da MultiRio fez da instituição um trabalho pioneiro no âmbito do serviço público municipal do país. A experiência e a credibilidade conquistadas ao longo de pouco mais de duas décadas renderam à empresa prêmios nacionais e internacionais na área de televisão e animação. Além disto, o prestígio da MultiRio nas áreas de educação e mídia possibilitou a instituição realizar e

48 A Secretaria Municipal de Educação atende mais de 658 mil alunos matriculados em aproximadamente mil escolas e 600 creches. O número de professores atuantes na rede é superior a 40 mil. Disponível em http://www.rio.rj.gov.br/web/sme/conheca-a-secretaria. Acesso em: 14 de mar. 2015.

${ }^{49}$ Relatório de Gestão, 1993-1996. MULTIRIO. 
coordenar a $4^{\text {a }}$ Cúpula Mundial de Mídia para Crianças e Adolescentes, em 2004, pela World Summit on Media for Children Foundation. Atualmente, a produção da MultiRio também é exibida pelos canais Futura, Rá Tim Bum, TV Cultura-SP e TV Escola.

A receita da empresa faz parte da verba destinada pela prefeitura à Secretaria Municipal de Educação, o que significa que seu financiamento é inteiramente custeado pelo órgão público municipal.

De acordo com o documento Relatório de Gestão referente a sua criação, a MultiRio foi concebida para ser um centro de pesquisa, ação e pensamento, democratizando as novas tecnologias e a linguagem das mídias nas escolas públicas da cidade ${ }^{50}$.

A produção da MultiRio está disponível numa plataforma midiática, que inclui: TV a cabo (Net Cidade) e aberta (Band Rio); internet (portal); Web TV e Web Rádio; DVD; pen card; mídia impressa - jornais, revistas, fascículos e livros; e satélite, para uso em cursos de capacitação.

As ações da MultiRio na televisão e em apoio pedagógico, no ano de 2014, podem ser observadas conforme a Tabela a seguir, baseada no Relatório de Produtividade da empresa:

${ }^{50}$ Conforme dados do IBGE, em 2012, existiam 2.319 escolas entre públicas e privadas de ensino fundamental na cidade, 748 de ensino médio e 2.062 escolas de ensino pré-escolar. Ainda segundo a pesquisa, o Rio de Janeiro conta com 64. 767 professores de educação infantil, ensino fundamental e médio nas esferas pública e particular. Num total de 1.171.177 alunos matriculados em toda a cidade. Considerando que este seria o público alvo e contando com a população geral da cidade - 6.320.446 habitantes — pode-se supor que tais programações exibidas por estas emissoras tenham alguma audiência e implicação no campo educacional. Disponível em: ftp://ftp.ibge.gov.br/Censos/Censo_Demografico_2010/Familias_e_Domicilios/censo_fam_dom.p df. Acesso em: 01 de fev. 2014. 
Tabela 1 - Produção Núcleo de TV, 2014.

\begin{tabular}{|c|c|c|c|}
\hline \multicolumn{4}{|l|}{ Mídia Televisiva } \\
\hline \multicolumn{4}{|l|}{ Escolares } \\
\hline \multirow[t]{2}{*}{ Séries/programas } & Total & & \\
\hline & 41 & & \\
\hline \multicolumn{4}{|c|}{ Informativos-culturais } \\
\hline \multirow[t]{2}{*}{ Séries/programas } & Total & & \\
\hline & 72 & & \\
\hline \multicolumn{4}{|c|}{ Aperfeiçoamento de professores } \\
\hline \multirow[t]{2}{*}{ Vídeos } & Total & & \\
\hline & 12 & & \\
\hline \multicolumn{4}{|c|}{ Capacitaçoes (nas CREs e encontros na MultiRio) } \\
\hline \multirow{2}{*}{$\begin{array}{l}\text { Professores, } \\
\text { diretores, } \\
\text { coordenadores, } \\
\text { gabinete. }\end{array}$} & Total & & \\
\hline & 06 & & \\
\hline \multicolumn{4}{|l|}{ Peças Programação } \\
\hline \multirow[t]{2}{*}{ Interprogramas } & Total & & \\
\hline & 11 & & \\
\hline Campanhas & 05 & & \\
\hline Efemérides & 27 & & \\
\hline Chamadas & 1295 & & \\
\hline Informativos & 114 & & \\
\hline Vídeo programa & 01 & & \\
\hline \multicolumn{3}{|c|}{ Veiculação da Programação/quantitativo } & Total \\
\hline BandRio & Sábados da & às $10 \mathrm{~h}$ & $36 \mathrm{~h}$ \\
\hline BandRio & $\begin{array}{l}\text { De segunc } \\
14 \mathrm{~h} 30\end{array}$ & sexta $14 \mathrm{~h}$ às & $203 \mathrm{~h}$ \\
\hline Net canal 14 & Diariamen & manhã/tarde & $2.395 \mathrm{~h}$ \\
\hline Net canal 14 & Diariamen & Noite & $728 \mathrm{~h}$ \\
\hline $\begin{array}{l}\text { Net } 57 \text { Cidades } \\
\text { Brasileiras }\end{array}$ & Horários rc & & $54.810 \mathrm{~h} 33$ \\
\hline
\end{tabular}

Dentre os gêneros mais comuns a sua programação, a MultiRio produz e exibe documentários, docudramas, programas de entrevistas, teledramaturgia e animação, este último, em técnicas de desenho animado, stop motion e outras. A empresa também produz programas para a capacitação docente, geralmente nos formatos teleaula e seminários, exibidos em sistema fechado para as escolas da rede, em períodos determinados pela Secretaria Municipal de Educação, conforme as necessidades do calendário escolar e política educacional. 
Quanto à audiência ${ }^{51}$, a MultiRio registra no horário em que vai ao ar $2 \%$ da audiência geral da TV Bandeirantes do Rio de Janeiro (cerca de dois milhões de domicílios). Este percentual corresponde a 40 mil domicílios ligados na programação da MultiRio nas regiões metropolitana e do Grande Rio. Ou seja, esses índices equivalem a quantidade de aparelhos ligados na programação educativa, gerando uma expectativa de audiência. Já a Net local disponibiliza a programação para 500 mil assinantes no RJ, não havendo pesquisa de televisores ligados nos horários de exibição da programação da MultiRio. Entretanto, não há como mensurar se de fato o telespectador está efetivamente assistindo a programação da MultiRio.

\section{1. Justificativa}

Escolhi estudar os produtores de programação educativa em televisão que trabalham na MultiRio por considerar a natureza e importância da empresa para o setor no Rio de Janeiro. Além disto, percebi a chance de ter entrada ao bastidor e às pessoas envolvidas no processo de produção justamente por fazer parte deste grupo e ter à mão um material empírico abundante. A minha condição privilegiada no acesso ao campo permite tentar responder às interrogações que me acompanham ao longo de quase uma década de trabalho com programação educativa em TV. E buscar responder às inquietações que me surgiram durante o mestrado em educação, exercendo um olhar minucioso com a expectativa de entender este tipo de produção agora pelos dois lados: comunicador e educador.

A MultiRio teve como seus primeiros diretores Walter Clark e as professoras Cleide Ramos e Regina de Assis. Em 2005, foi realizado pela primeira vez um concurso público, que admitiu mais de 150 funcionários qualificados para as áreas de televisão, tecnologias da educação, impressos e setores administrativos. E foi por meio desta seleção, que ingressei na empresa para exercer o cargo de repórter de TV.

\footnotetext{
${ }^{51}$ De acordo com o Ibope, um ponto de audiência equivale a $1 \%$ do universo pesquisado. Por exemplo, se o universo em questão for á área do Grande Rio de Janeiro, que contém 3.966.024 domicílios e 10. 998.205 indivíduos, $1 \%$ corresponde a 39.600 domicílios e 109.982 indivíduos aproximadamente.
} 
Os produtores de televisão educativa da MultiRio constituem objeto de estudo interessante, pois tal grupo é formado por comunicadores e professores numa tentativa ora difícil ora harmoniosa de construir uma programação educativa regida pelos princípios da educação e da comunicação, cujo propósito é servir ao meio escolar e à sociedade. O que, apesar da trajetória exitosa, às vezes, não logra sucesso.

Quis estudar a produção porque é o lócus onde todo o esforço para educar acontece. Os efeitos na recepção já são exaustivamente analisados em diferentes estudos, sob diversas teorias. Meu desejo foi observar como, onde, quem faz televisão educativa e quais valores e critérios utilizam para esta produção, evidenciando, talvez, parâmetros sociais e culturais que tais sujeitos reproduzem ou tentam transpor.

Kaplún (1998) é enfático em dizer que antes de tratar de comunicação, ainda que este seja o propósito de quem a faz, é preciso refletir sobre educação. Para ele, em primeiro lugar, quando se faz comunicação educativa, está sempre buscandose, de uma maneira ou de outra, um resultado formativo. Diz-se, segundo o autor, que estamos sempre produzindo nossas mensagens para que os destinatários tomem consciência de sua realidade ou sejam capazes de pensar criticamente. Desta forma, realça Kaplún, concebemos os meios de comunicação que executamos como instrumentos para uma educação popular fundada num processo educativo transformador. Em vista disto, é preciso clarificar como nós, produtores de conteúdo educativo transmitido através dos meios de comunicação, vemos a educação; qual concepção de educação subjaz nossas práticas de comunicação.

O terreno é fértil para enriquecer o debate sobre a interlocução desta área, revelando questões do campo a fim de contribuir para o melhor entendimento do tema, instigar novas pesquisas e inspirar outras propostas de produção, tanto no campo teórico quanto na práxis.

\section{2. \\ Metodologia}

A importância desta pesquisa se justifica pela ampliação do debate a cerca da contribuição da TV educativa para o campo educacional, considerando não 
somente o ponto de vista dos educadores, mas também, dos profissionais de comunicação, enriquecendo a discussão sobre o papel destas duas áreas de conhecimento no campo educacional.

A análise debruça-se sobre como a educação está ou não inserida no contexto deste tipo de programação, como é apresentada e entendida por estes profissionais, espelhando ou não estas representações nos programas. Por conseguinte, serão detalhadas as impressões destes profissionais, além de ampliar a discussão com proposições teóricas na construção e exame dos dados.

O estudo de caso tem como objeto de estudo os produtores responsáveis pela elaboração e execução de programas educativos da MultiRio.

Desde 2005, em cumprimento da legislação pública, os funcionários ingressam na empresa por meio de concurso público. Exceto os cargos denominados de confiança da presidência, indicados pelo Executivo municipal. Os profissionais aprovados na seleção pública tiveram de comprovar, por meio do exame, saber sobre a empresa e a respeito das legislações federais da Educação, Cultura, Desporto e Lei de Diretrizes e Bases da Educação, além dos conhecimentos técnicos de comunicação. Dessa maneira, espera-se que o aprovado identifique a razão fim da empresa: produzir produtos educativos, não havendo possibilidade de fazer qualquer outro tipo de produção senão com este objetivo.

Tal peculiaridade mostra-se importante a este estudo, pois pode possibilitar a verificação da identificação ou não destes profissionais com o campo Educação, além da bagagem formativa na área da Comunicação.

Outra particularidade deve ser considerada neste estudo. A dinâmica do mercado de televisão faz com que muitos dos profissionais comissionados já tenham trabalhado em outros canais deste tipo como TV Brasil, TV Futura, TV Escola ou retornem a elas, quase sempre constituindo rodízio entre tais emissoras e a MultiRio, adquirindo, portanto, know-how sobretudo empírico neste tipo de programação.

Os critérios de escolha pela MultiRio consideraram a natureza da empresa, sendo esta uma produtora pública de mídia educativa, criada e diretamente vinculada à Secretaria Municipal de Educação do Rio de Janeiro, servindo como veículo oficial de capacitação de alunos e professores da rede municipal de ensino. 
Ademais, programas produzidos pela MultiRio são exibidos em TV aberta e fechada, para a comunidade escolar e a sociedade, além de também serem vinculados pela TV Futura, TV Escola, TV Cultura SP e Canal Rá Tim Bum. Ponderou-se ainda, o fato de a MultiRio contar diretamente no modo de produção com professores do ensino público municipal e profissionais de comunicação, atuando em conjunto na produção dos programas.

Cabe, indubitavelmente nesta pesquisa, refletir sobre a participação da audiência deste tipo de programação. Porém sem aprofundamento, pois esta dissertação escolheu estudar este tipo de produção a partir dos bastidores, de quem a produz, e não pelo viés do receptor. Este assunto será mencionado sempre a partir da opinião dos produtores e de argumentos de especialistas em broadcasting educativo, que interpretam esta matéria como essencial a todo tipo de transmissão. Portanto, este não é um estudo de recepção.

A escolha pelo estudo de caso deve-se a necessidade de entender "como" e "por que" é feita educação pela TV em broadcasting.

O estudo de caso deve ter preferência quando se pretende examinar eventos contemporâneos, em situações onde não se podem manipular comportamentos relevantes e é possível empregar duas fontes de evidências, em geral não utilizadas pelo historiador, que são a observação direta e série sistemática de entrevistas. (DUARTE, 2005, p. 219)

Destarte, o problema característico dessa investigação gira em torno da discussão a partir da perspectiva dos profissionais de televisão educativa na construção de seus programas e quais os objetivos desta programação.

Diante da problematização contextualizada, é preciso buscar respostas para questões-chave:

a) O que estes profissionais entendem por conteúdo educativo?

b) Como esta percepção influiu nas decisões por pautas, linguagem, formatos, discursos?

c) Quais valores e objetivos são adotados na elaboração da programação educativa?

d) Qual enfoque é privilegiado: educação formal? Educação informal?

e) Quem é o público alvo, segundo os produtores?

Em consequência das questões apresentadas e ampliadas por todo o corpo deste trabalho surgem hipóteses que procuram responder a tais perguntas. $\mathrm{O}$ mapeamento acerca da estrutura da MultiRio e suas condições de produção, 
processo semelhante a outras empresas do setor, faz com que algumas respostas provisórias incorram em hipóteses como:

a) Profissionais de comunicação e de educação divergem sobre o que é conteúdo educativo, especialmente, a partir da área de formação, evidenciando uma tensão nas relações entre estes.

b) A percepção que prevalece sobre qual conteúdo comunicar e em qual forma e linguagem é a do profissional de educação, cabendo a execução aos profissionais de comunicação.

c) Os valores utilizados objetivam a formação e a educação da audiência em conteúdos escolares curriculares e promoção da cidadania.

d) A educação formal, escolar, constitui o principal enfoque da programação, ainda que o viés informal perpasse alguns programas.

e) O público alvo da programação educativa em TV é o professor e a comunidade escolar, embora em alguns momentos tenha-se a pretensão de atingir uma audiência ampla e diversificada.

Considerando as questões e hipóteses apresentadas, esta dissertação tem como objetivo geral a ser alcançado investigar qual a concepção de conteúdo educativo compreendida pelos profissionais de mídia e educação que trabalham em TV educativa e de que forma esta acepção norteia a produção destes programas e, consequentemente, atingir objetivos específicos:

a) Verificar quem são os profissionais responsáveis pela criação e produção envolvidos nestes produtos.

b) Analisar de que maneira estes saberes e perfis dialogam e atendem ao campo educacional.

c) Analisar as motivações de produção destes programas, se para uso didático em sala de aula, formal, ou mais amplo, informal, evidenciando qual a intencionalidade educativa dos mesmos.

d) Conceituar e analisar os critérios utilizados, caracterizando objetivos para a programação.

e) Contribuir para a reflexão sobre o papel educativo da televisão e como os profissionais de mídia vem desenvolvendo ideias para o uso da TV no campo educacional.

O método de investigação elegido para este estudo incorporou critérios utilizados pela Teoria Fundamentada dos Dados, Grounded Theory, desenvolvida 
por Barney Glaser e Anselm Strauss (1967). Grounded Theory é um modo de pesquisa qualitativa que principia a descoberta indutiva de teorias a partir dos dados analisados sistematicamente. O aprendizado ocorre a partir dos dados e não a partir de uma visão teórica existente que levaria a hipóteses e deduções a serem confirmadas ou não ao final da pesquisa. Pela Grounded Theory o foco está no fenômeno pesquisado, que impulsiona o desenvolvimento da teoria através de uma contínua interdependência entre a coleta de dados e a análise. Ou seja, não há uma teoria prévia, conceitual, a ser testada ao final. Mas sim, o desejo de entender o fenômeno, como e por que os participantes agem de dada maneira e como ocorrem os desdobramentos. As teorias conclusivas emergem da análise dos dados.

As características desta metodologia são a construção da teoria além da codificação de dados; a ausência de um quadro conceitual que antecede ao início da pesquisa; análise e conceitualização alcançadas por meio do processo de coleta de dados e comparação constante.

Esta escolha deu-se principalmente em consequência da parca oferta de estudos sobre o setor e sobre discussões envolvendo as duas áreas comunicação e educação em televisão - como broadcasting, para além do usual recurso formal de educação a distância observada durante o levantamento bibliográfico.

Desta forma, visando garantir o rigor da pesquisa, seguiu-se o modelo de Pandit (1996) que define o processo de construção da Grounded Theory em cinco passos fundamentais: desenho da pesquisa, coleta de dados, ordenação de dados, análise de dados e comparação com a literatura.

$\mathrm{Na}$ fase "desenho da pesquisa", foi realizada a revisão da literatura, definindo a questão da investigação: qual perspectiva os profissionais de televisão educativa adotam na construção de programas educativos? Diante deste levantamento, selecionou-se o caso MultiRio.

O próximo passo foi a "coleta de dados", desenvolvendo os instrumentos para a coleta de dados, aplicação dos pré-testes e ida a campo. A seguir, foi feita a “ordenação dos dados”, organizando os dados em ordem cronológica e transcrição do material.

Imediatamente iniciou-se a fase de "análise dos dados", desenvolvendo as categorias de análise. De acordo com Glaser e Strauss (1967), as categorias 
emergem dos dados. Neste momento, o pesquisador soma a sua amostra dados que aumentem a diversidade de informações. O objetivo é desenvolver e fortalecer a teoria emergente, o "theoretical sampling”. O pesquisador também realiza anotações durante a análise, descritas por Glaser (1967) como memos, relacionando às categorias, suas propriedades e cruzamentos entre elas.

E é a partir das reflexões dos memos que se avança para a próxima fase que consiste na escrita e "comparação com a literatura". Seguindo este percurso e considerando o objeto de estudo, elegeu-se os sujeitos da pesquisa.

O processo de produção de programas para TV implica em procedimentos próprios do meio, como orçamento, equipamentos tecnológicos, transporte, logística de exibição. Mas, também, na produção de conteúdo a partir de impressões, aspectos subjetivos dos sujeitos que trabalham na produção e é preciso considerar o repertório cultural, a personalidade, as experiências profissionais e de vida destes sujeitos. Para tanto foi preciso mapear as funções que atuam na produção dos programas, dentro de um contexto mais amplo que incluiu as diretrizes editoriais da empresa.

A escolha dos sujeitos a serem estudados considerou a exigência na capacidade destas fontes em ajudar a responder o problema proposto, observando a condição de dar informações confiáveis e significativas à questão de pesquisa. Duarte (2005) esclarece quanto à seleção dos informantes que:

Boa parte da validade da pesquisa está associada à seleção. É possível, entrevistando pequeno número de pessoas, adequadamente selecionadas, fazer um relato bastante consistente sobre um tema bem definido. Relevante, neste caso, é que as fontes sejam consideradas não apenas válidas, mas também suficientes para responder à questão de pesquisa, o que torna normais, durante a pesquisa de campo, novas indicações de pessoas que possam contribuir com o trabalho e, portanto, ser acrescentadas à lista de entrevistados. [...] A seleção de entrevistados em estudos qualitativos tende a ser não probabilística, ou seja, sua definição depende do julgamento do pesquisador e não de sorteio a partir do universo, que garante igual chance a todos (característica das amostras probabilísticas). Existem dois tipos básicos de amostras não probabilísticas para uso em entrevistas qualitativas: por conveniência ou intencional. (DUARTE, 2005, p.68)

De acordo com o autor, a seleção intencional é a escolha feita pelo pesquisador por juízo particular, como por exemplo, conhecimento do tema ou representatividade subjetiva, podendo selecionar conhecedores específicos do assunto. 
Para este estudo, foram selecionadas oito categorias de sujeitos: presidência, consultor de mídia e educação, diretor de programação, diretor artístico/diretor de programa, produtor, jornalista/roteirista, editor, cinegrafista.

Essas funções foram escolhidas porque são elas as criadoras transversalmente de formatos, linguagens e conteúdos para os programas, sendo responsáveis pelo produto como um todo.

Presidência - além de dirigir a empresa, a escolha e determinação de criação de produtos e intencionalidade com os mesmos é também encargo da presidência, cuja demanda muitas vezes é apresentada diretamente pela secretaria municipal de educação.

Consultor de mídia e educação - a este professor cabe verificar a possibilidade educativa de tais produtos e dialogar no processo criativo com as áreas de comunicação e educação, considerando seus respectivos saberes e linguagem. É também responsável pelo conteúdo pedagógico do programa, incluindo orientações educativas.

Diretor artístico/diretor de programa - este profissional é o maestro executor da confecção do produto. Ele coordena as atividades de toda a equipe, incluindo produtor e jornalista. É responsável também pela parte artística do produto, determinando movimentação de câmera, cenários, elenco. É atribuição do diretor, supervisionar a edição, na fase de pós-produção. Ao diretor artístico cabe conciliar conteúdo e linguagem televisiva ao produto.

Produtor - é responsável em concretizar a ideia desenvolvida pelo diretor e/ou roteirista. Ele prepara o projeto considerando o conceito do programa e custos de produção. Lida com o roteirista, o elenco, a direção, a edição e a exibição. Atua em todas as frentes desde a pré-produção à pós-produção.

Diretor de programação - é ele quem negocia com as emissoras a exibição dos produtos e interesse das mesmas na faixa educativa, verificando inclusive audiência dos produtos e logística de exibição e distribuição.

Jornalista/roteirista - é responsável pelo conteúdo do projeto. Ele pode ser editor de conteúdo, roteirista ou repórter ou todas estas funções ao mesmo tempo. O conteúdo, assuntos e conceitos utilizados na mensagem que se quer comunicar são organizados em um argumento nas produções dramáticas ou numa pauta do programa, quando não é ficção. É ele o responsável em redigir os textos das 
matérias, ou o roteiro, entrevistar pessoas e especialistas, tornar as ideias mensagens para o receptor.

Editor de imagem - é o responsável por construir com imagens e sons a narrativa dos produtos. Mais que mero montador de sequências de imagens, seu olhar é fundamental para comunicar uma informação, uma intenção, por entreter o espectador e garantir a comunicação da mensagem com o público. Trabalha diretamente com a equipe.

Cinegrafista - é com os olhos dele que a audiência vai registrar o conteúdo.

É responsável por capturar as imagens e fatos que contarão ao público a mensagem que se quer passar. Informa, sensibiliza, documenta, registra o que o campo seja em externa ou em estúdio através da imagem.

Neste estudo, todos estes profissionais são chamados por produtores, uma vez que de fato todos - independente da função - colaboram na construção da mensagem comunicada. Todos produzem conteúdo seja audiovisual ou pedagógico. A participação de todos resulta no que vai ao ar.

\subsection{1. Instrumentos de pesquisa}

A abordagem qualitativa desta dissertação apoia-se nos recursos metodológicos do questionário de identificação de respondente e da entrevista individual em profundidade.

Antes de iniciar a entrevista, foi aplicado um questionário breve de identificação, cujo objetivo de coletar dados básicos contribuiu para contextualizar as informações, iniciando com naturalidade a atividade, estabelecendo um ambiente de confiança e interesse. Por meio deste instrumento foi possível identificar as características da amostra da pesquisa por sexo; idade; categoria profissional; formação acadêmica; tempo de experiência em TV; tempo de experiência em televisão educativa; tempo de serviço na empresa; tempo de experiência no cargo exercido; e interesse pela área correlata, a partir da leitura de bibliografia específica.

À medida que o questionário era encerrado, iniciava-se então a entrevista. Duarte (2005) explica que a entrevista em profundidade é uma técnica dinâmica, 
flexível apropriada para a apreensão da realidade, de questões relacionadas ao íntimo do entrevistado, descrição de processos complexos.

É uma pseudoconversa realizada a partir de um quadro conceitual previamente caracterizado, que guarda similaridade, mas também diferenças, com a entrevista jornalística. São próximas no objetivo de buscar informações pessoais e diretas por meio de uma conversação orientada, no cuidado, rigor e objetivo de compreensão [...] e na noção de que há, explicitamente, um participante interessado em apreender o que o outro tem para oferecer sobre o assunto. A entrevista como técnica de pesquisa, entretanto, exige elaboração e explicitação de procedimentos metodológicos específicos: o marco conceitual no qual se origina, os critérios de seleção das fontes, os aspectos de realização e o uso adequado das informações são essenciais para dar validade e estabelecer as limitações que os resultados possuirão. (DUARTE, 2005, p. 64)

À vista disso, o tipo de entrevista em profundidade adotado como instrumento desta pesquisa foi o semiaberto, com questões semiestruturadas a partir de um roteiro de perguntas, cujas respostas indeterminadas trouxeram múltiplos entendimentos sobre o tema.

Duarte (2005) especifica que o modelo semiaberto parte de questionamentos básicos, apoiados em teorias e hipóteses que amparam a pesquisa, e que, em seguida, oferecem outras interrogações, fruto de novas hipóteses que surgem à medida que as respostas trazem reflexões no curso da entrevista. Essa flexibilidade que enriquece a investigação é conjugada a um roteiro de controle. A vantagem deste instrumento é permitir uma estrutura de comparação de respostas e articulação de resultados. Outro aspecto considerado vantajoso da entrevista é que esta possibilita captar a expressão corporal do entrevistado, tonalidade da voz e ênfase nas respostas, obtendo dados com elevado nível de profundidade. A desvantagem está na identificação do informante ao entrevistador. Contudo, para a confiança das informações, foi garantido o anonimato dos informantes, identificando-os por números.

$\mathrm{O}$ roteiro de perguntas para a entrevista foi elaborado considerando o problema de pesquisa e a familiaridade e qualificação dos entrevistados com e sobre o assunto estudado. Aqui interessou saber desde o modo de produção, a origem de um programa, quem determina formato e linguagem, por exemplo, à percepção de cada produtor sobre o que é conteúdo educativo.

Foram listadas 17 perguntas, gerais e especificas sobre o tema. As questões foram estruturadas de modo a observar a concepção que estes produtores têm sobre conteúdo educativo, quais valores permeiam esta concepção; a dicotomia ou 
não de entretenimento e educação; a relação entre profissionais de comunicação e educação neste fazer televisão educativa; a compreensão sobre os objetivos e as perspectivas para o futuro da televisão educativa.

As entrevistas seguiram um roteiro-guia, com as perguntas-chave, gerais. $\mathrm{Na}$ medida em que os respondentes explanaram sobre o assunto, as perguntas foram aprofundadas por meio de outras específicas até esgotar as questões. $\mathrm{O}$ roteiro de entrevistas foi construído, então, desta forma:

1. O que é um programa educativo?

- Com quais adjetivos você poderia definir programação educativa?

2. Você pode dar exemplos de gêneros de programas educativos?

3. Vamos ler este resumo da portaria interministerial $\mathrm{n}^{\circ} 651$, dos Ministérios da Educação e das Comunicações, de 1999, que entende por programas educativos aqueles que apoiam os sistemas de ensino em qualquer nível, educação permanente e formação para o trabalho, e orientação profissional, como por exemplo, os telecursos.

E também, atividades de divulgação educacional, cultural, pedagógica, programas de caráter recreativo, informativo ou de divulgação desportiva, desde que contemplem aspectos educativos-culturais.

Na sua opinião, qual destes enfoques é mais educativo? E o mais apropriado ao meio televisão?

4. Como surge um programa?

- Quem define conteúdo, formato, linguagem?

5. Na MultiRio trabalham em conjunto, no processo de produção de programas, professores consultores pedagógicos e profissionais de comunicação. Como é esta relação?

6. Conteúdo educativo em televisão é entretenimento?

- Programação educativa é escola na TV?

7. Você acredita que os professores encaram a TV como um espaço educador?

8. Quem é o público da televisão educativa?

-É o professor?

9. Um dos problemas da televisão educativa, apontado por especialistas, é a baixa audiência. Quais seriam os motivos da pouca representação nos índices? 
10. Como explicar o sucesso de produções educativas como Vila Sésamo e Castelo Rá Tim Bum ao longo de anos?

11. Você acredita que o programa que você produz educa?

12. Qual o futuro da televisão educativa?

Com finalidade de aperfeiçoar e validar o roteiro foi realizado um pré-teste com três sujeitos dos cargos em questão, nas mesmas condições previstas para a realização da pesquisa.

Para neutralizar a possível autocensura excessiva por conta da dupla condição de pesquisadora e integrante do grupo estudado, recorreu-se às considerações de Pierre Bourdieu (2008). O autor atenta para a incapacidade da neutralidade estéril almejada pelos pesquisadores na tentativa de uma ciência imparcial, visto que o homem é histórico-cultural, imerso num universo simbólico cujos sentidos, significados e conceitos emergem da interação entre os sujeitos.

... porque permanecem dominados pela fidelidade a velhos princípios metodológicos que são frequentemente decorrentes, como o ideal da padronização dos procedimentos, da vontade de imitar os sinais exteriores mais reconhecidos do rigor das disciplinas científicas. (BOURDIEU, 2008, p.693)

Bourdieu ressalta a natureza da pesquisa científica como promotora de conhecimento por natureza, mas que sendo realizada na interação social, esta pode representar - e atuar até, como uma violência simbólica capaz de alterar as respostas. As distorções criadas a partir daí devem ser reconhecidas e dominadas, numa dinâmica refletida e metódica, sem engessar a pesquisa. Esta capacidade relacional mais atenta, apurada é construída, técnica, metodológica, mas nem por isto limitante. $\mathrm{O}$ autor considera que:

Só a reflexividade, que é sinônimo de método, mas uma reflexividade reflexa, baseada num 'trabalho', num 'olho' sociológico, permite perceber e controlar no campo, na própria condução da entrevista, os efeitos da estrutura social na qual ela se realiza. (BOURDIEU, 2008, p.694)

Desta forma, Bourdieu justifica uma comunicação "não violenta" entre pesquisador e pesquisado e acredita que a entrevista é um ato de intrusão, que pode gerar apreensões errôneas sobre o objeto e a uma fala, uma voz, controlada do pesquisado. Para isto, o autor considera que é preciso o saber sobre o objeto. É necessário esclarecer o sentido que o pesquisado faz da situação, da pesquisa em geral, da relação particular em que se estabelece, do objetivo da pesquisa e explicar as razões que o fizeram participar. 
É efetivamente sob a condição de medir a amplitude e a natureza da distância entre a finalidade da pesquisa tal como é percebida e interpretada pelo pesquisado, e a finalidade que o pesquisador tem em mente, que este pode tentar reduzir as distorções que dela resultam, ou pelo menos, de compreender o que pode ser dito e o que não pode, as censuras que o impedem de dizer certas coisas e as incitações que encorajam a acentuar outras. (BOURDIEU, 2008, p. 695)

Diante deste cenário de significações advindas do social, Bourdieu sugere uma escuta ativa e metódica: afastada da pura não intervenção da entrevista dirigida, quanto do dirigismo do questionário. Uma das práticas proposta pelo autor é uma "empatia dirigida e controlada" do objeto. Faz-se necessário adotar a linguagem e entrar no ponto de vista do pesquisado, com uma construção metódica forte do conhecimento das condições objetivas. Para tanto, a familiaridade com as pessoas interrogadas deve ser acentuada como recurso metodológico, uma vez que proporciona confiança do entrevistado no pesquisador, pois este saberia de onde se fala, como se fala e as implicações deste discurso verbal e simbólico, com códigos de ética próprios da pertença. Estes aspectos, a fim de minimizar distorções, têm limites, pois tal empatia não deve ser artificializada.

Desta forma, para esta dissertação, a fim de que a familiaridade entre os sujeitos pesquisados e a pesquisadora não comprometesse a análise, as entrevistas com os produtores foram realizadas em horário oposto ao horário de trabalho da pesquisadora, sinalizando que naquele momento quem estava ali era a observadora. A marcação dos dias e horas das entrevistas foi feita formalmente por meio do e-mail institucional da universidade. O local escolhido para a coleta de dados com os entrevistados foi o set de um programa de entrevistas, dentro de um estúdio. $\mathrm{O}$ ambiente silencioso e já cenografado para entrevistas permitiu que a pesquisadora se colocasse no lugar já conhecido dos produtores como entrevistadora e pudesse realizar as entrevistas, gravadas por um gravador de voz portátil, numa condição um pouco mais distanciada. A composição física da área onde são produzidos e gravados programas adquiriu status de espaço social, considerado na obtenção dos dados. Desta forma, a familiaridade com a colega de trabalho ganhou formalidade neste jogo de papéis.

Contudo, Bourdieu ressalta que há de se ter atenção com a armadilha criada pela familiaridade: a banalização ou a sensação de já conhecer o que é dito. Cada história relatada é singular, única. E é preciso vigiar - por parte do pesquisador, 
o jogo entre os sujeitos: o próprio e o entrevistado no momento da entrevista. Observar a si mesmo para não se descobrir guiando respostas, determinando sentidos e mistificando o resultado a partir da própria subjetivação do pesquisador. Uma falha nesta vigília pode resultar na teatralização das respostas, gerando significações falsas, uma vez que o entrevistado pode responder àquilo que se espera dele como já pré-significado, estereótipos e não a informação genuína, honesta.

Então, no ambiente ao mesmo tempo acolhedor - por ser uma sala cenográfica, composta de duas poltronas aveludadas, confortáveis, num ambiente que representa uma sala de estar intimista, com uma longa cortina de veludo; arcondicionado e a portas fechadas - e de trabalho, a entrevista foi realizada sob a pré-disposição em ouvir o que no dia a dia não é dito, o que é realizado e divulgado. Oportunidade enriquecedora para o processo de estudo e também de trabalho, mas, sobretudo a possibilidade de ampliar horizontes e refletir sobre as questões apresentadas.

O isolamento simbólico provocado pelo estúdio tonificou as medidas adotadas para a realização da entrevista. Antes de iniciá-la, cada participante foi alertado de que naquele momento estava diante de uma pesquisadora do departamento de Educação da PUC Rio, e que apesar do tom de conversa e familiaridade, não seria adequado por parte da observadora nenhuma interação no sentido de opinar, expor conclusões ou qualquer outra avaliação ou crítica. O tom adotado foi neutro, buscando minimizar os riscos de distorções.

Os aspectos éticos da pesquisa foram observados quanto à avaliação da relação risco-benefício, a obtenção do consentimento informado e a garantia da preservação da privacidade. Esta dissertação foi aprovada pelo comitê de ética da PUC-Rio, acatando suas recomendações. 


\section{5. Resultados e reflexões}

Aqui, é conveniente fazer a seguinte observação: para a análise dos dados, em alguns momentos, fez-se importante recorrer às percepções de especialistas do setor, consultados ao longo dos capítulos anteriores, enriquecendo a interlocução com os fundamentos de Mario Kaplún. Esta conduta foi assumida por acreditar que a discussão a partir do ponto de vista de quem elabora e executa este tipo de conteúdo - e de não ser considerado objeto de exaustivas análises sobre o tema, comprovadamente constatado durante o levantamento bibliográfico - é fonte privilegiada de incrementar as reflexões sobre o tema. Isto posto, segue a análise.

\section{1. Perfil da amostra}

A apuração dos dados inicia-se apresentando o panorama do grupo formado pelos 10 produtores selecionados para o estudo de caso, com base nos resultados coletados a partir do questionário de identificação dos respondentes, verificados na Tabela a seguir. 
Tabela 2 - Características da amostra

\begin{tabular}{|l|l|}
\hline Produtores & $\mathbf{N}^{\mathbf{o}}$ \\
\hline Sexo & \\
Masculino & 5 \\
Feminino & 5 \\
\hline Idade & Média 48 anos \\
Mais jovem & 35 anos \\
Mais velho & 73 anos \\
\hline Categoria profissional & \\
Concursado & 7 \\
Provisório & 3 \\
\hline Formação Acadêmica & \\
Ensino médio & 1 \\
Graduação & 9 \\
Pós-graduação/especialização & 4 \\
Mestrado & 3 \\
Doutorado & 1 \\
\hline Tempo de experiência em TV & Média 16 anos \\
Menor & 8 anos \\
Maior & 39 anos \\
\hline Tempo de experiência em TV educativa & Média 11 anos \\
Menor & 0,5 anos \\
Maior & 25 anos \\
\hline Tempo de exercício na MultiRio & Média 7 anos \\
Menor & 0,5 anos \\
Maior & 14 anos \\
\hline Tempo de exercício no cargo atual & Média 7 anos \\
Menor & 0,5 anos \\
Maior & 12 anos \\
\hline & \\
\hline
\end{tabular}

Quanto ao interesse pela área correlata, todos os profissionais de educação disseram já ter lido algum autor de comunicação. Destaque para o filósofo Pierre Lévy e o sociólogo Manuel Castells, ambos teóricos da cultura digital. Dos profissionais de comunicação, pouco mais da metade afirmou ter lido sobre educação. Célestin Freinet, Lev Vygotsky, Jean Piaget, Paulo Freire, Darcy Ribeiro, Cristovam Buarque, Humberto Maturana foram os autores citados.

São adultos que se habituaram ao domínio da televisão como mídia dominante no país nas últimas décadas ${ }^{52}$. A familiaridade com a linguagem

${ }^{52}$ Dados do censo 2010, do IBGE , revelam que quase a totalidade dos domicílios do país — mais de $95 \%$ — tem televisão. Cerca de $81 \%$ dos lares brasileiros têm rádio e apenas $30,7 \%$ têm acesso à internet. Disponível em: ftp://ftp.ibge.gov.br/Censos/Censo_Demografico_2010/Familias_e_Domicilios/censo_fam_dom.p df. Acesso em: 15 jan. 2015. De acordo com a Pesquisa Brasileira de Mídia 2015, divulgada pela 
televisiva vai além da condição de audiência, uma vez que a maioria possui mais de 10 anos de experiência em TV. Quase a totalidade possui graduação na área correspondente a função. Nota-se também que há interesse em seguir a formação, investindo em pós-graduação stricto e lato sensus.

Contudo é possível identificar evidências que sugerem interesses singulares quanto à leitura sobre a área correlata. Tratando-se de um grupo diretamente envolvido com televisão, os profissionais de educação apresentaram entusiasmo pelo universo da cybercultura, o que pode sugerir o crescimento da importância das tecnologias digitais em rede e suas implicações na educação; mas, também; sinalizar a superação ou readequação do valor da televisão enquanto mídia educativa na atualidade, condição questionada pelos entrevistados da pesquisa sobre o futuro da TV educativa durante o estudo. Já os profissionais de comunicação demonstraram entusiasmo pela leitura sobre especialistas em teorias da aprendizagem sócio-históricas, escolanovistas e defensores de uma educação cidadã libertária e democrática, o que pode significar o entendimento que os meios de comunicação podem servir à educação para além de mero suporte, configurando-se como linguagem que propicia a conscientização da cultura, ambiente social, história e papéis desenvolvidos pela escola e sociedade, dialogando, comunicando estas relações.

Traçadas as primeiras impressões é preciso seguir nas questões de entrevista, cujo debate inspira novas formas de pensar e propõe direções tanto à pesquisa sobre o setor quanto aos modos de produção, a começar pela compreensão sobre a matéria prima, senão muitas vezes, também produto final deste exercício televisivo: o conteúdo educativo.

\section{2.}

O que é um programa educativo?

Os produtores atribuíram adjetivos e objetivos para definir o que é um programa educativo. O substantivo conteúdo foi empregado com o sentido de

secretaria de comunicação social da presidência da república, 95\% dos entrevistados, ouvidos em todo o país, afirmaram ver TV, sendo que $73 \%$ têm o hábito de assistir diariamente. Em média, os brasileiros passam $4 \mathrm{~h} 31$ por dia expostos ao televisor, de $2^{\mathrm{a}}$ a $6^{\mathrm{a}}$-feira, e $4 \mathrm{~h} 14$ nos finais de semana. Disponível em: http://www.secom.gov.br/atuacao/pesquisa/lista-de-pesquisas-quantitativas-equalitativas-de-contratos-atuais/pesquisa-brasileira-de-midia-pbm-2015.pdf. Acesso em: 15 jan. 2015. 
substancial, relevância, enriquecido, evidenciando aqui que conteúdo pode não ser forma. Os adjetivos reflexivo, provocativo, ético foram citadas em maior frequência pelos entrevistados, como é possível notar nas respostas a seguir.

Entrevistado 1: "Pra mim, um programa educativo é um programa que leva conhecimento. Que desperta algum tipo de conhecimento no espectador. Se isso levar conhecimento, algum tipo de formação pro espectador, pra mim é um programa educativo. Ele tem que se propor a levar um conteúdo relevante, um conteúdo que traga algum crescimento, algum conhecimento pro espectador. O programa tem que se propor a isso".

Entrevistado 5: "Programa educativo eu acho que tem que ser um programa que não só passe o conteúdo de alguma informação, de algum tema. Mas que provoque uma reflexão também sobre esse tema".

Entrevistado 6: "Pra mim, um programa educativo é aquele que provoca. Eu acho que para formação de professor, o programa educativo é aquele que provoca no professor a vontade de conhecer mais sobre aquele assunto, informa sobre aquelas questões que estão sendo colocadas, mas eu vejo muito mais como algo que vai problematizar, que vai instigar, do que algo que vai formar efetivamente".

Todavia, um dado chama a atenção na análise das respostas dos produtores a esta pergunta. Dos 10 entrevistados, quatro afirmaram que todo programa é educativo, independente de receber esta classificação ou não. Os entrevistados 4 e 7 vão adiante na afirmação e deixam emergir o fato de que a normatização ou a reputação de um programa educativo passa pela classificação como tal, sendo esta chancelada por quem entende de educação, isto é, professores sejam estes os profissionais em exercício em TVs educativas ou constituintes do público telespectador.

Entrevistado 4: "Eu entendo que todo programa ele é educativo. Se você partir do ponto de vista que você está produzindo alguma informação, e você está repassando essa informação para um grupo de pessoas, ele tende a educar. [...] A educação ela pode ser boa ou ruim, mas ela é educação de qualquer forma. Esse critério é mensurado por quem pensa educação, acho que é mais por aí. Você pode receber uma programação, um programa popular, que não é um programa escolar, é um programa de entretenimento, e aquele grupo de pessoas que gosta daquele programa de alguma forma está sendo educado praquilo ali, praquilo que ele está recebendo. Mas quem vai mensurar se é ruim ou bom não é quem está recebendo, é quem trabalha com educação, quem pensa educação, quem orienta em educação". 
Entrevistado 7: "Se a gente partir do pressuposto de que a gente aprende com qualquer coisa, qualquer programa é educativo. Se a gente aprende com tudo, com a vida, com as relações, qualquer experiência é um aprendizado, qualquer programa é educativo. Agora, pode rotular que programa educativo é o programa caracterizado por uma relação de ensino, assumidamente uma relação de ensino, aonde alguém vai se propor a explicar alguma coisa, ensinar alguma coisa, para alguém que teoricamente vai assistir aquele programa com o desejo de aprender algo específico. Não sei, acho que é isso".

As respostas apresentaram dois lados significativos de uma mesma conjuntura. O primeiro, de que há uma intenção clara em propor à audiência algum tipo de aprendizagem, seja esta de conteúdos curriculares ou questões de cidadania, por exemplo. Porém, o problema parece estar em como proporcionar esta experiência.

A discussão avança ainda para o papel de quem determina o que é educativo. Pelas respostas dos produtores, cabe aos especialistas em educação designar o que é ou não educativo. E à audiência interpretá-lo como sendo ou não, conforme seus interesses próprios.

Esta postura é criticada por Kaplún $(1996 ; 1999)$ pois representa o modelo exógeno, onde a audiência é receptora do conteúdo transmitido pelo programa. Em consequência ao estímulo, surgiria a reflexão sobre o assunto apresentado. Kaplún, em seus estudos sobre a televisão, vai questionar esta percepção conteudista e hierárquica: o que ocorre de fato ante ao televisor? Segundo sua análise, existem modos de recepção que não passam pelo prazer gratificante ${ }^{53} \mathrm{e}$ nem pela intensa atividade simbólica, que leva ao telespectador codificar a mensagem e atribuir alguma significação. Para Kaplún, nem sempre assistir televisão é um ato significativo, consistente, portanto, em receber e decodificar significados. O consumo de bens simbólicos depende de onde o sujeito está

\footnotetext{
${ }^{53} \mathrm{O}$ autor coloca que os estudos sobre audiência foram embasados por duas correntes ao longo das últimas quatro décadas. Até os anos de 1970, a análise crítica, de cunho estruturalista, considerou as estruturas econômicas e políticas de poder, suas mensagens, metamensagens e ideologias como forma de manipulação. Para explicar o consumo massivo dos meios, recorreu-se a imagens robóticas tais como alienação, imposição e anestesiamento. Nesta concepção, o público é inerte às mensagens, aos meios, constituindo-se um objeto passivo, indefeso. Em resposta a essa visão mecanicista, advieram novos paradigmas com ênfase na revindicação do receptor, que agora passa a ser sujeito interatuante. Da imposição, a lógica passa a ser a da aliança. Ou seja, se a televisão conquista tanta audiência é porque esta oferece mensagens que coincidem com as necessidades simbólicas e gostos sociais, resultando numa recepção autenticamente gratificante (KAPLÚN, 1996).
} 
situado social e culturalmente, inscrito num contexto que interfere nas maneiras de recepção.

Em seus estudos, Kaplún (2001) explica que hoje é possível entender que, além de educação formal e não formal ${ }^{54}$, existe uma terceira categoria: a informal, que não vê a educação como o simples resultado de ações mais ou menos ligadas ao sistema escolar prescritivo, mas como a soma de todos os estímulos sociais, incluindo mensagens midiáticas, que atualmente ocupam um lugar central no dia a dia da sociedade. É nesta dimensão que podem-se verificar, de forma mais acentuada, os esforços educacionais feitos por meio dos veículos de comunicação. Neste modo, já não existe um educando a quem se anuncia e explicita claramente a intenção de oferecer-lhe educação e que, por sua vez, coloca-se expressamente na atitude de recebê-la. Não exige-se do receptor a intencionalidade, a vontade consciente de aprender. O telespectador recebe espontaneamente a mensagem, porque ele está interessado, porque a mensagem foi capaz de captar a atenção e mobilizar a resposta da audiência. Em outras palavras, porque esta mensagem foi, por assim dizer, "competitiva" em relação a outras ofertadas ao consumo do público.

Desta forma, postular que tal programa leve conhecimento requer aferir o que a audiência faz com a mensagem recebida. E se a mesma encontra ressonância no ambiente sociocultural dos telespectadores. Porém, como estimar esta aprendizagem se a televisão não pressupõe o feedback, limitação própria do meio? Talvez, há de se considerar como retorno, e não diálogo, a capacidade de zapping dada ao telespectador.

Kaplún (1999) diz que este modelo de comunicação que se presume levar conhecimento é embasado em conceitos e dados que o professor e o comunicador consideram importantes, dando pouca importância ao diálogo e à realimentação, reproduzindo via broadcasting o sistema escolar convencional, confundindo informação, mera instrução, com formação. Ainda que exista o desejo de provocar uma reflexão. Contudo, sem a obtenção do retorno da audiência sobre este processo, é ousado dizer que tal programação, de fato, provoca algum tipo de aprendizagem.

${ }^{54}$ Kaplún entende por educação formal a educação tradicional restrita a espaços formais de educação, como a escola. Não formal, a educação oriunda de meios e espaços populares, sociais e culturais, resultado da troca entre os indivíduos, baseada numa matriz de educação popular freireana. 
No entanto, alguns dos produtores entrevistados apresentaram em suas respostas conflito de convicções sobre o que é educativo, dizendo que todo programa educa.

Recorrendo aos especialistas em broadcasting, esta percepção dos produtores da MultiRio encontra ressonância no setor, como explica Seldes (1970). O autor afirma que possuímos um sistema plural de educação — desde a educação infantil à pós-graduação — e que tais instâncias escolares são meros aspectos dessa educação. As demais frações desta educação consistem na publicidade, nos meios de comunicação, no púlpito, nas campanhas políticas e, naturalmente, nas transmissões de TV. O especialista sustenta que a principal diferença da TV educativa em relação à TV comercial, no que toca à educação, é o desejo real de fazer com que as pessoas saibam alguma coisa sobre determinadas matérias, sem pretender esgotar o assunto. Este é um passo necessário e essencial para a aprendizagem, que vai além daquele ofertado pela TV comercial, que consiste apenas em ouvir falar do assunto. Segundo Seldes, "saber algo a respeito de um assunto, através da TVE, significa saber alguma coisa acerca da verdade, da essência, das relações e da importância desse assunto" (SELDES,1970, p.207). Porém, a TV educativa é mais uma das diversas ofertas educativas que configura as diversas formas de educação.

"Os homens se educam entre si mediados pelo mundo", afirma Kaplún (1998, p.49). Tomando por base esta concepção, é possível ser educado por um telejornal, por uma novela, por um programa de auditório mesmo que estes sejam transmitidos por uma televisão comercial, sem o fim devidamente explicitado de educar.

Contudo, se todo programa educa, por que denominar programação educativa? Ou mesmo programação educativa e cultural? Quiçá, a resposta a esta questão seja encontrada nas questões à frente.

\section{3.}

\section{Gêneros de programas educativos}

Os produtores designaram como educativos os gêneros entretenimento, informação, educação e publicidade ${ }^{55}$, conforme as seguintes respostas: quiz,

${ }^{55}$ Verificar os tipos no capítulo dois. 
palco, campanhas, infantil, desenho animado, auditório, teleaula, musical, ficção, debates, jornalístico/informativo, dramaturgia, entrevista, animação, documentário.

O gênero documentário foi citado por nove entre os 10 entrevistados. Seguido pelos gêneros animação, em cinco respostas, e dramaturgia, mencionado por quatro entrevistados. Os gêneros ficção e jornalísticos/informativos foram citados cada um por três respondentes. Debates e Entrevistas apareceram em duas respostas. Os demais foram citados apenas por um entrevistado cada.

Com isto, é possível notar a tendência em unir informação e diversão. A maioria considerou os gêneros jornalísticos ou correlatos à dramaturgia como gêneros educativos. Destaque para os classificados como entretenimento, como animação, dramaturgia e ficção. A figura a seguir mostra a frequência total das respostas.

Figura 1 - Gêneros educativos

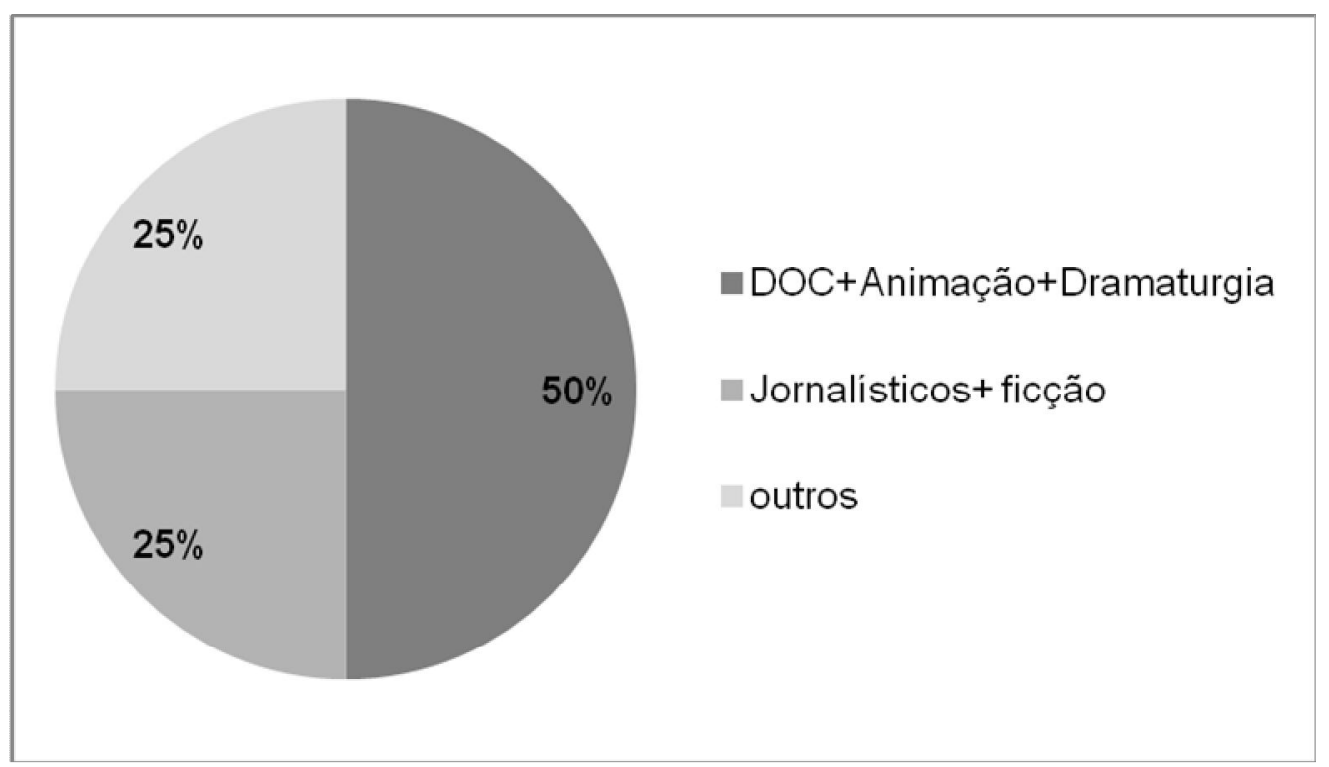

Este dado sugere que educar pela TV consiste em apresentar conteúdo, informação, sustentados por uma linguagem que desperte o prazer, o entretenimento, princípio televisivo anteriormente apresentado. Entretanto, os percentuais podem demonstrar, ainda, que para os produtores observados, o processo de aprendizagem passa majoritariamente pelo lúdico. 


\section{4.}

\section{Portaria interministerial no 651, de 1999}

Após a leitura da portaria $\mathrm{n}^{\mathrm{o}} 651$, de 15 de abril de $1999^{56}$, publicada pelos Ministérios da Educação e das Comunicações, que trata das concessões para execução dos serviços de radiodifusão com finalidade exclusivamente educativa, foi perguntado aos entrevistados qual dos enfoques apresentados na legislação seria o mais educativo e o mais apropriado ao meio televisão.

O gráfico a seguir mostra a frequência de respostas dos entrevistados quanto à pergunta qual destes enfoques é o mais educativo? A maioria dos entrevistados acredita que temas culturais são mais educativos, evidenciando um posicionamento por uma abordagem educativa não formal.

Figura 2 - Categorias de programas educativos conforme portaria ${ }^{\circ} 651$

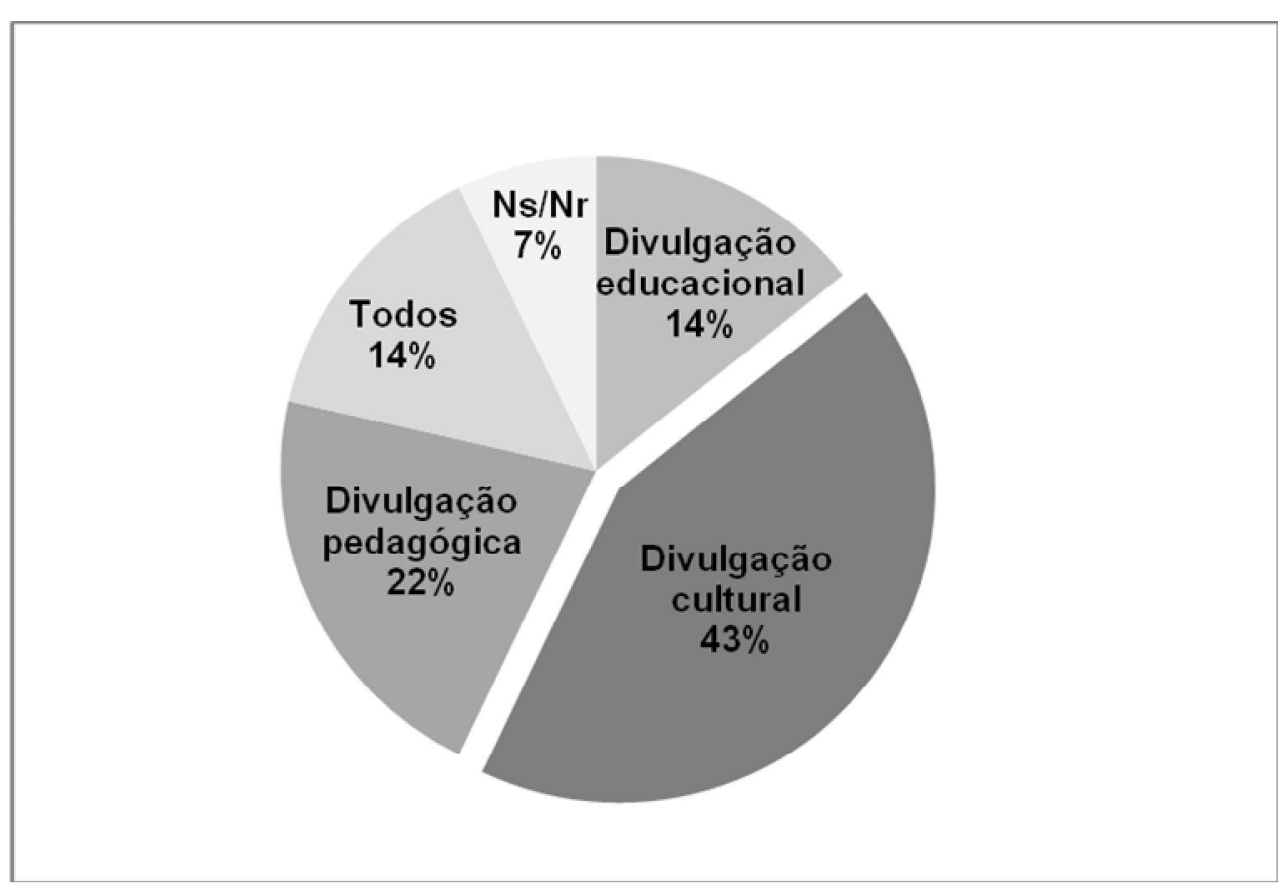

${ }^{56}$ Conforme os artigos $1^{\circ}$ e $2^{\circ}$ do documento, por programas educativo-culturais entendem-se aqueles que, além de atuarem conjuntamente com os sistemas de ensino de qualquer nível ou modalidade, visem à educação básica e superior, à educação permanente e formação para o trabalho, além de abranger as atividades de divulgação educacional, cultural, pedagógica e de orientação profissional. São também os programas de caráter recreativo, informativo ou de divulgação desportiva, se neles estiverem presentes elementos instrutivos ou enfoques educativoculturais identificados em sua apresentação. 
Ainda que tenham sido citados programas de divulgação pedagógica foi possível notar, na maioria das respostas, a predileção por produtos relativos à temática cultural.

Este dado abre a discussão sobre o papel cultural da TV educativa. A preferência por programas culturais encontra em uma das suas pressuposições a configuração de público que assiste a este tipo de programação.

Contudo, há risco de predominar neste tipo de programação uma visão restrita sobre o que é cultural, e claro, merecedor de espaço na veiculação. Braum et al (1970) explica que, geralmente, pressupõem-se por audiência deste tipo de emissora uma grande proporção de pessoas "com alto nível cultural", profissionais liberais, formadores de opinião que influem e determinam o tom cultural das comunidades em que vivem. Pessoas já escolarizadas que poderiam influenciar os não escolarizados. Ou seja, esta percepção sugere que a TV educativa educa os já escolarizados, os já “educados”.

Kaplún (1999) diz que esta percepção é senso comum entre os broadcasters, alertando que entende-se, erroneamente, por definição de programa cultural o conteúdo distanciado da vida concreta das pessoas e alheio à realidade ao redor. Fato que contribuiria para o estereótipo de que a TV educativa é rebuscada demais para dialogar com todas as camadas da população.

Os produtores justificaram suas respostas conforme a conotação atribuída por cada um sobre o que é educativo e cultural, a maioria entendendo cultura pela perspectiva sócio-histórica, mais ampla, como é possível notar:

Entrevistado 5: "O primeiro parágrafo fala de programas que apoiam sistemas de ensino em qualquer nível. São as teleaulas, os telecursos, os programas de capacitação que a gente faz aqui, que tem um objetivo claro que é você melhorar a formação do professor, ou dar subsídios ou dicas de aula, de como o professor deve dar aula de determinados assuntos. Isso é muito específico com esse enfoque da formação, formal, você formaliza o programa educativo nessa linha. Mas aí, eu acho que a gente faz também um outro grupo de programas que tem o enfoque do segundo parágrafo: que tem uma divulgação educacional, cultural, tem caráter recreativo, informativo, esporte. [...] Eu defendo a ideia de que quando você tem uma atividade lúdica, educacional, com cultura você educa".

Entrevistado 6: "Quando eu penso na teleaula eu penso muito naquela coisa arrumadinha, formatadinha, como uma aula na televisão. Isso não. Pra mim, não. Isso acabou! Chegou esse tempo! Agora, uma aula na televisão que atenda o processo de formação, que tenha sido produzida a partir do conhecimento 
de que precisa atender a demanda de uma determinada rede, que tenha qualidade de produtos com todas as possibilidades que tem a comunicação, aí eu acho que dá uma coisa bem legal. E aí, eu acho que tem vários modelos pra fazer isso. Daqui, eu ficaria com atividades pedagógicas [...] porque divulgar, só divulgação não basta. Não basta só divulgar. Tem que ir mais fundo. Programas de caráter recreativo, ok. Mas enfim, eu acho que tudo isso tem que ter, mas se eu fosse pensar na educação, a questão é pedagógica”.

Entrevistado 9: "Se você quer um efeito curricular, são os primeiros. Essa parte mais dentro do sistema de apoio mesmo. Agora, se você entende educação no sentido amplo, e que ela se dá em todos os momentos da sua vida, [...] então os segundos aqui atenderiam talvez mais especificamente. Entretanto, eu acho, que essas coisas precisam começar a ser confundir um роисо".

Entrevistado 10: "O mais educativo? Complicado. Eu acho que tudo que passa mais pelo cultural, eu acho que atinge mais o seu viés educativo. Teleaulas eu sempre tive um pouco de preconceito, eu já até fiz programas no Futura, mas eu não sei se atinge, eu acho que fica tão tatibitate, não sei o quanto atinge um objetivo assim. Eu penso num programa educativo numa coisa, numa formação mais global, mais tipo: a pessoa ter com aquela informação mais poder de discussão".

Porém, as respostas dos entrevistados mostram a percepção sobre a dimensão cultural do conteúdo, propiciando uma aprendizagem sob a perspectiva sócio-histórica. Esta corrente considera que atividades cognitivas básicas do indivíduo ocorrem de acordo com sua história social. Ao transpor para a TV a cultura local e questões relativas a ela - e até mesmo outras culturas, é possível estimular, levar informação, gerar conflito, incentivando mais ainda o desenvolvimento porque apresenta ao indivíduo questões que lhe correspondem diretamente ou lhe provocam estranhamento. A percepção dos entrevistados sobre aprendizagem em TV, certamente, passa pelo caráter social e cultural da comunidade.

Quanto às respostas, sobre qual dos enfoques apresentados pela portaria $e ́ o$ mais adequado ao meio TV, é evidenciada uma contradição. Aqui, observa-se que, apesar da defesa de que o meio televisão é entretenimento e de considerar a temática cultural a mais adequada, quanto ao enfoque mais apropriado ao meio $T V$, a maior parte dos entrevistados concordou que todos os enfoques são apropriados. Inclusive, o modo teleaula - contemplado nos temas dispostos à formação para o trabalho, orientação profissional e apoio escolar e que foi 
reprovado pelos produtores como gênero cativante e eficaz nas respostas anteriores.

Esse dado sugere o conflito entre forma e conteúdo, entre informação e entretenimento e entre o uso instrumental da TV e o seu uso enquanto linguagem no processo educativo.

\section{5.}

Como surge um programa?

Ainda que haja espaço para a participação de todos os envolvidos na criação, construção e produção dos programas, a ideia original do produto parte de uma solicitação da Secretaria Municipal de Educação ou da presidência da MultiRio. Apenas quatro dos 10 entrevistados disseram que o processo é colaborativo. O processo de criação foi descrito como hierárquico conforme as respostas, mesmo as que consideram como um o processo colaborativo.

Entrevistado 1: "Eu vejo duas formas mais claras: uma nasce de uma questão, que surge espontaneamente através da vivência mesmo da pessoa. Uma indagação, alguma coisa que leva ela a querer produzir um conteúdo audiovisual sobre aquilo. Isso é uma forma de criação. A outra forma é quando é uma forma de encomenda. Quando uma instituição da SME que trabalha, por exemplo, com uma questão da Psicologia nas escolas, de agressividade, chega pra empresa, pra MultiRio, isso acontece muito aqui, e encomenda um produto para atender aquela demanda que eles estão precisando. Aí surge o programa. Agora, depois que você tem uma ideia de criar um programa, de abordar um tema, aí você vai para o desenvolvimento. Como você vai abordar aquilo? Que formato? Que linguagem audiovisual que você vai criar? Quais os recursos de produção que você dispõe para criar aquilo? Não adianta você ter uma ideia maravilhosa, mas você não tem a super câmera que precisa para realizar aquilo. Nem o prazo. Nem as ilhas de edição. Então, entre o surgimento da ideia, você tem o desenvolvimento e a adaptação daquilo que foi o recurso produtivo".

Entrevistado 2: "Há uma demanda. Por parte de quem? Do cliente. Que é esse cliente? O principal cliente é a Secretaria Municipal de Educação. Então, a Secretaria Municipal de Educação tem uma demanda que é trabalhar formação dos professores que atuam num determinado projeto das própria secretaria, um projeto de alfabetização, digamos assim. A MultiRio senta, e aí é preciso que ela sente com o representante da Secretaria responsável por este projeto e comesse a ouvir o quê que ele quer e se o quê que ele quer pode ser transformado". 
Entrevistado 5: "Olha, aqui na MultiRio é engraçado, porque vem a encomenda de que a gente deve fazer um produto determinado, e aí a gente tem que pensar o formato, pensar a proposta, pensar a linguagem, se vai ter apresentação de estúdio ou se vai ser em externa, se não vai ter apresentador. Aí, a gente elabora o documento. Vai lá pra aprovação. E aí a presidência decide o que ela quer. Entendeu? A gente quer um programa que não tenha estúdio com entrevista, aí ela fala: não, mas eu quero esse programa com estúdio e com entrevista. Então a gente na verdade perde um certo tempo de pensar esse formato, porque a gente até propõe, mas no fim das contas a vontade que prevalece é da presidência, a gente apenas segue o que se decide".

Entrevistado 8: "eu acho que o programa vem de uma ideia, ele pode partir de uma sugestão ou ele pode partir de um pedido da Secretaria: poxa, na escola a gente está enfrentando um problema muito sério sobre, sei lá, bullying, que eles gostam. E aí, assim, no meu mundo ideal, os programas, os temas, as abordagens são criadas coletivamente. Você acaba montando uma equipe porque dentro de televisão, as tarefas, elas são segmentas até pra dar agilidade, até pra todo mundo trazer a sua experiência de como está se relacionando com a vida pra dentro daquele programa; então assim, de alguma forma é montado de uma forma colaborativa, né, temas, abordagens, todo mundo sugere e vai ter uma pessoa que vai colocar isso no papel que é o roteirista. Junto com o diretor que também é uma figura que acaba colocando muito a visão, como ele está pensando em abordar, quais a linhas que ele quer, oformato de programa é uma coisa que vem muito do diretor. Mas a equipe toda colabora. Mas isso é no meu mundo ideal. Aqui, na experiência daqui da empresa, às vezes, eu acho que acontece. Aqui na MultiRio, no meu dia a dia de trabalho, eu acho que muitas vezes o mundo ideal ele vem aqui. Ele acontece. A gente dialoga com ele. Porque é possível, por mais que um programa ele seja uma demanda da presidência da empresa, quando ele chega aqui no núcleo de TV, pra ele realmente acontecer, e que muitas vezes também ele chega com uma equipe já formada por uma indicação da presidência também, aqui existe uma troca de ideias pra ele acontecer"!

Entrevistado 9: "Aqui na MultiRio, ele surge muito da Secretaria de Educação. Em que sentido? Nós acompanhamos semanalmente, até então, agora a cada quinze dias, uma reunião da Secretaria em que a política de trabalho é discutida. E ali nós vamos percebendo os pontos que a gente precisa dar reforço. E muitas vezes alguns programas nascem juntos por demanda direta: quero esse tema! Mas independente disso, cabe muito mais à MultiRio, e praticamente sozinha, definir a sua grade de programação”.

As falas dos entrevistados marcam que há tensão entre os profissionais de educação e comunicação, quanto à responsabilidade de pensar um conteúdo 
educativo e executar esta ideia. E que, talvez, o papel defendido por Kaplún de educomunicador não seja tão fácil de ser desempenhado, ou mesmo, pretendido.

Esta tensão fica mais evidente na questão que se segue.

\section{6.}

\section{Como é a relação entre educadores e comunicadores?}

Cinco dos 10 entrevistados afirmaram ser difícil a relação entre os profissionais de educação e os profissionais de comunicação que atuam em conjunto na produção dos programas da MultiRio. Aqui vale o alerta de que estes responderam que esta relação também é difícil em outras emissoras do gênero, onde já trabalharam ou ainda prestam serviço concomitantemente.

Quatro produtores disseram que já fora pior em outros anos este entendimento, mas que atualmente a relação está melhor. Apenas um não respondeu.

Mesmo apresentando melhora para os quatro entrevistados, se considerarmos que eles assumiram a dificuldade nesta relação, o resultado chega a 90\% da amostra, ou seja, quase a totalidade dos entrevistados reconhece algum grau de tensão neste relacionamento. As palavras duelo e catastróficas chegaram a ser utilizadas para definir e adjetivar a relação entre os profissionais de educação e comunicação. A origem do conflito está em conhecer ou desconhecer um a área do outro. Mas também, aponta para uma questão subjacente: a percepção sobre a escola e a TV. A dicotomia aparece de formas variadas nas respostas que se seguem.

Entrevistado 1: "Eu acho que existe uma certa dificuldade aí nessa interação. Porque os profissionais de educação tem uma convivência muito da sala de aula que o profissional de mídia não tem tanto. Eu acho que, assim, falta pra pessoa da educação, da consultoria, conhecer mais o meio audiovisual, tanto a linguagem do audiovisual quanto os meios de produção, pra poder saber o que pedir, como pedir e o que pode pedir, e o que observar, como falta também para o profissional de comunicação conhecimentos pedagógicos do funcionamento de uma sala de aula mesmo, de conceitos de educação, falta muito. [...] O consultor de educação às vezes tem uma tendência de fazer a coisa muito quadrada e chata, porque não conhece justamente a linguagem dos audiovisuais, como tornar aquilo dinâmico, entendeu? Ele transpõe a aula pro audiovisual. E não é. É diferente. Porque quando você vai ver um produto audiovisual, normalmente, ou uma televisão por exemplo, se é chato você muda de canal ou desliga! Desliga a televisão, não 
vai receber aquilo que está sendo passado. Quando você está dentro numa sala de aula, você está naquele horário de aula ali com o seu professor. Então você está ali ou porque você quer, quando é um curso que você quer, ou porque você tem que estar ali. Então você não pode desligar o professor".

Entrevistado 2: "Considerando-se o período de 95 a 2000 e hoje, eu sinto uma enorme diferença! A relação hoje é muito mais fácil, muito mais tranquila. Naquele momento inicial da MultiRio, às vezes a gente tinha alguns duelos com os profissionais de televisão. Porque eles olhavam pros nossos pedidos e para nossas demandas, da Secretaria no caso, como demandas fora do contexto da televisão. Como se a gente quisesse fazer dentro do programa uma sala, transformar o programa numa sala de aula ou de um curso de formação ou então de uma universidade ou até numa sala de aula de ensino fundamental. Então, em alguns momentos a gente tinha que discutir, fazer valer - a expressão pode até ser esta mesma fazer valer o nosso papel como representante da Secretaria. Houve momentos de tensão. Mas que a gente aprendeu a lidar".

Entrevistado 6: "Engraçado. Porque eu estou vivendo uma coisa muito legal. E vivi antes também, mas agora é completamente diferente porque eu estou aqui - Essa relação era muito engraçada. Nossa, vamos para a MultiRio! Como é que a gente vai falar com aquelas pessoas? Meu Deus, eles sabem tudo de comunicação e vai ser um terror, como é que eu vou gravar e tal? [...] Era sempre uma coisa assim: eu não sei o que eles sabem e eи preciso que eles saibam o que eu sei. Eu não preciso saber de comunicação. Realmente não. Não estou dizendo que não é um conhecimento que eu não queira ter. $O$ que eu preciso é que os profissionais da comunicação entendam a importância daquilo que eu sei para os professores. [...] Mas também esse conteúdo não é nada se ele não estiver bem trabalhado. E aí é que eu acho que isso precisa se aproximar. Porque se eu sei um pouquinho sobre esse universo da comunicação, eu também posso pensar esse conteúdo de forma mais adequada a esse grupo. Então, é um processo mesmo de doação. Eu preciso estar aberto pra entender esse universo da comunicação. Não dominar, mas eu preciso entender. Porque se eu não entender eu vou me fechar no conteúdo. E isso não vai dar em nada".

Entrevistado 10: "Ela não é ruim não. Sinceramente, eu acho que não é uma coisa catastrófica. Mas eu acho que o profissional de comunicação, ele às vezes tende a lutar pra que aquele conteúdo se torne interessante, entendeu? Enfim, pra que as pessoas queiram ver. Em todos os detalhes que eu digo: na linguagem de edição, na linguagem de gravação, na arte do estúdio, no figurino dos apresentadores, ele quer que aquilo seja gostoso de ver. Isso é um profissional, pelo menos os bons profissionais querem que as pessoas assistam seus programas, se prendam nele e queiram assistir os próximos episódios. E às vezes, eu acho que o conteúdo, a equipe de conteúdo que 
seriam esses professores, eles ficam muito ligados no conteúdo $e$ às vezes tem esse conflito".

Se os produtos para TV educativa são originalmente pensados e executados por profissionais de educação e comunicação e há conflito, como garantir que os programas de fato cumpram o seu dever em educar através da TV? Estaria aí a causa do estereótipo da TV educativa em ser monocórdia e aborrecida?

Braum et al. (1970) defende que a TV educativa deve depender de maneira vital da orientação de professores na determinação do conteúdo dos programas, na forma de sua apresentação e eficiente utilização. Para o broadcaster, educar é papel do educador, que certamente planeja um objetivo de aprendizagem ao propor determinado conteúdo. Mas quando o conteúdo ganha "corpo", este vai ser modelado, torneado à luz da técnica do espetáculo, da própria da TV. Por exemplo, uma aula sobre microrganismos. Minutos percebendo a atividade de uma bactéria no microscópio pode ser excitante nos primeiros momentos de visualização. Mas apresentá-las no tamanho da tela, numa sequência de ocorrências, como se comportam no organismo ou meio ambiente vai depender de um roteiro, um ritmo de narrativa, seleção de imagens que melhor informam o conteúdo, quiçá uma reação curiosa que precisou ser gravada por horas para que aquele trecho fosse capturado, tudo isto faz parte do espetáculo que constitui a televisão. É a linguagem do meio. Logo, se uma área de saber não compreende a amplitude e a importância da outra no processo educativo, o resultado pode deixar a desejar e, portanto, não educar.

Conforme visto no capítulo 1 , a TV educativa requer mão de obra especializada. No caso da MultiRio, os profissionais de comunicação tiveram seus conhecimentos técnicos e seus saberes sobre questões educativas testados por concurso público. Os professores consultores são nomeados por indicação e, em alguns casos, cessão de profissionais diretamente envolvidos com a Secretaria Municipal de Educação. Sendo assim, como explicar o conflito?

A resposta pode estar em como uma área percebe a outra. Se a escola é vista como algo lento e desinteressante e a comunicação tida puramente como suporte para o conteúdo, o choque vai permanecer por décadas a frente.

À vista das respostas dos entrevistados e da discussão a respeito da relação entre os profissionais de educação e comunicação neste tipo de TV, foi possível verificar a necessidade de desconstruir relações de poderes, de formar 
profissionais híbridos e repensar o papel da escola e o discurso escolar tanto na instituição, quanto em sua extensão eletrônica, a TV, para que esta não seja repositório de estereótipos e reflexo de uma fala verticalizada. O debate sobre abrir o pensamento escolar à criatividade, ao lúdico, ao sensorial e ao deleite, sem abrir mão da reflexão e produção de conhecimento, é ainda mais evidente na questão a seguir.

\section{7. \\ Conteúdo educativo em TV é entretenimento?}

Os dez dos produtores entrevistados responderam que sim, conteúdo educativo em televisão é entretenimento. Contudo houve um dado que chamou atenção. Um dos produtores respondeu que sim, mas reconheceu que este é um desafio para a televisão. E, imediatamente, se contradisse, afirmando que conteúdo educativo em TV não é entretenimento quando questionado por que desafio?

Entrevistado 1: "Sim, pode ser entretenimento. De que forma você passa o conteúdo educativo, né? Por exemplo, um documentário pode ser entretenimento. Essa conjugação às vezes é difícil. Talvez esse seja um desafio pra televisão. [...] Conteúdo educativo em televisão não é entretenimento. Porque é diferente, por exemplo, você fazer uma aula passeio no jardim botânico e você, num final de semana, ir passear no jardim botânico, é diferente. Embora a aula passeio tenha um aspecto de entretenimento, quer dizer você está aliando algo divertido, prazeroso naquela sua aula, o conteúdo educativo está ali. Enquanto que você vai fazer um passeio simplesmente no jardim botânico o educativo não está ali. Tá ali a sua vivência e tal. Mas o educativo não, primordialmente, está ali. Por isso que eu acho que conteúdo educativo não é entretenimento. Ele pode ter um aspecto de entretenimento, mas ele não é".

Essa resposta ajuda a revelar, novamente, o olhar que estes profissionais têm do espaço de aprendizagem e, principalmente, da escola. Em vários momentos a dicotomia chato/divertido; sério/lúdico; responsabilidade ou compromisso/diversão aparece nas respostas. E mesmo os produtores que acreditam que conteúdo educativo em televisão é entretenimento, suas falas também deixam emergir insegurança e contradição, circunstância que sugere que a característica do meio TV, "entretenimento", talvez não este vinculada à aprendizagem. Conforme as respostas, escola e ensino estão desvinculados de prazer e diversão. Imersos no ambiente educativo, os produtores evidenciam o 
quão forte é o estigma escolar e, logicamente, a TV educativa reflete essa concepção.

Entrevistado 2: "Conteúdo educativo em televisão é entretenimento? Pode, pode ser. Vai depender do olhar de quem produz e do olhar de quem assiste. O meu olhar é viciado porque é um olhar de professor. Então, eu olho pra novela e fico percebendo no quê que ela pode ser discutida, a novela é um entretenimento. Mas o meu olhar já vai direto em algumas cenas, em alguns temas, em algumas propostas que são colocadas e que podem ser trazidas para a sala de aula, podem ser discutidas com o professor, podem servir pra discussão de um conceito, de uma proposta até de um trabalho interdisciplinar numa escola. Ou até da própria secretaria, enfim, mas eu olho sempre mais pensando na escola. Então, um programa educativo pode ser entretenimento sim, mas vai depender de quem estiver assistindo".

O mesmo entrevistado diz que o programa educativo é engessado justamente por ser educativo.

Entrevistado 2: "A televisão tem programas que são muito mais atraentes do que esse programa que é todo marcado, que é todo pensado, que é todo controlado. Porque esse programa é um programa que tem um controle imenso! Eu não sei dos outros que não são educativos. Mas eu sei que nesses, a gente tinha um imenso controle de que nada ficasse sem ser explicado, sem ser respondido. Quando as respostas dos não alcançavam o limite máximo da pergunta, a gente mesmo fazia perguntas pra exigir do convidado que ele respondesse efetivamente aquilo que tinha sido perguntado ou por uma pessoa de casa ou por um professor a partir da escola. Então, a gente tinha noção de que não era um programa de entretenimento, ele não tinha essa intenção. E a televisão ela trabalha com, ela tem uma função, ela precisa atrair o telespectador. Mas o nosso nem sempre tinha as imagens mais atraentes porque ele tinha as imagens da escola. Que são imagens que os professores já conhecem, que são familiares. Ele está vendo os alunos que são perecidos com os dele, os professores que são parecidos com ele, com os colegas. E ele (programa) tem um controle que talvez para televisão não seja a melhor forma de utilização do meio".

Entrevistado 3: "Acho que sim. Porque eu acho que televisão é entretenimento. Se você de certa maneira acha que aquilo tem que ser exibido, tem que ir pro ar, você tem que ter uma visão de entreter também. Porque não adianta você fazer um senhor programa educacional, que a pessoa fique dois minutos $e$ desligue a TV depois. Ela tem que olhar aquilo, ver aquilo, se interessar por aquilo e continuar assistindo, senão o canal se rompe, a transferência de informação é rompida. Então, eu acho que você tem a coisa de seduzir, de conquistar mesmo o espectador. Então eu acho que é entretenimento também. Educativo tem que ser entretenimento também". 
Entrevistado 4: "É entretenimento. É entretenimento. Não é o entretenimento no sentido amplo da palavra, né? Quando você fala em televisão, você não pensa em televisão educativa. Ninguém fala: ah, eu vou assistir a TV educativa, né? Eu vou assistir televisão pra ver qualquer outro programa menos o programa educativo. Mas aquele público - que é um público muito pequeno, mas que existe - ele liga a televisão para assistir a TV educativa. Hoje tem gente que liga a televisão $e$ vai assistir o canal de documentário, vai assistir lá a Discovery. Então, eu vejo que esse público é um público pequeno, mas é um público que assiste e vai ver televisão educativa. Mas, evidentemente, acho que $90 \%$ ou mais vão ver televisão para entretenimento, ninguém vai... ah, vou ver o programa educativo! Só se interessar muito. [...] Mas ninguém liga a TV educativa pra ficar horas assistindo".

Entrevistado 7: "Ah, tem que ser. Tem que ser. Porque aprender tem que ser divertido, tem que ser um entretenimento".

Entrevistado 8: Pode ser, pode ser. Ué, por que conteúdo educativo tem que ser chato? Você não tem que se divertir? Não pode ser uma coisa tipo de você só aproveitar, usufruir, tem um momento bom, relaxado, enfim, de prazer ou a reflexão não faz parte do lazer ou do prazer? Pra mim está tudo misturado. Eu super tenho prazer quando, tipo, tenho uma reflexão. Então, programa educativo pode ser entretenimento, desde que, é porque no meu ponto de vista entretenimento tem a ver com se divertir com alguma coisa. Se divertir com alguma coisa te gera prazer e gerar prazer faz você olhar com outros olhos pras coisas também. Programa educativo não é uma coisa só chata que você tem que ficar olhando, tem que ficar assistindo pra adquirir alguma coisa. Tomara que você adquira, tomara que, assim, e isso é que é muito louco, porque, não sei por que tem essa divisão! Refletir sobre algo é não se interessar sobre algo? É pra ser chato quando você reflete sobre alguma coisa? Não sei por que criaram esse negócio: programa educativo não pode ser entretenimento! Tudo educa! Isso é que é muito louco, porque tudo educa"!

Partindo do pressuposto de que esta dissertação tem por premissa refletir sobre a TV educativa, vale olhar para a escola e sua relação com a sociedade, afinal, disposta nas carteiras da sala de aula está uma audiência que anseia pelo professor, que por sua vez vai comunicar a esta mesma audiência informações que farão deste um processo prazeroso ou não de aprendizagem. A sala de aula é o primeiro set e dependendo de como este processo comunicativo ocorre, ou vem ocorrendo, vamos reproduzi-lo na TV educativa e na sociedade, apesar do esforço dos produtores em evitar que isso aconteça. 
Os produtores foram questionados se TV educativa é escola na TV?A frequência de respostas mostra que para a maioria dos entrevistados TV educativa não é escola na TV. É neste momento que os respondentes evidenciam aquilo que entendem por escola:

Entrevistado 3: "Não. Não. Eu acho que a escola não pode ser jogada pro lado para ser substituída por outra coisa. Eu acho que as duas coisas tem que andar juntas, assim. Eu acho que escola é fundamental. TV, mídia educativa é fundamental. Eu acho que mais uma parceria do que uma separação”.

Entrevistado 5: "Não tem que ser escola na TV. Eu acho que não tem que ser. Pelo contrário, eu acho que a escola hoje em dia tem muito que sair dos seus muros. E a TV pode ser um caminho. Ao invés de a gente botar a escola dentro da TV, é a $T V$ que tem que tirar a escola de dentro de si, do seu espaço e ganhar o mundo"!

Entrevistado 6: "Não. Pra mim, não. Porque escola pra mim é um lugar, é um espaço. Escola tem que ter conflito, relação, articulação, tem que ter toque, afetividade. Esse lugar pra mim é um lugar sagrado, e é mesmo"!

Entrevistado 7: "Não. Não. Ah, escola é outra coisa, né? Eu acho que escola é tudo! Escola é vida, escola é crescimento, escola é aprendizado, mas eu digo assim, de tudo. É onde você começa a fazer amizade, onde você começa a se relacionar. Escola é tudo. E não tem como isso ser levado pra televisão, pra um programa, pra uma TV educativa. Televisão educativa é televisão educativa. Escola é outro papo".

Entrevistado 8: "Ah, lá vem vocês com tudo amarradinho! Escola? Espero que a escola não seja mais escola na escola, nem escola na TV, nem escola em lugar nenhum, porque a escola está uma bosta (sic)! Escola é vida, sabe? Então tomara que programa educativo não seja escola na TV como é a escola hoje. Agora se a escola se transformar, programa educativo pode ser escola na TV. A escola é chata. A escola é muito chata. A escola é chatíssima! Então se você aproxima um programa educativo da escola, se você bota a grade curricular para a ser a base de um programa educativo e trata as coisas no mesmo tom, nesse tom de um detentor do conhecimento querendo passar outra informação, isso é chato. A educação, o conhecimento tem que partir do interesse de quem faz, entendeu"?

Entrevistado 9: "Não. Escola é escola. A televisão hoje como ela é, ela informa muito mais do que educa, no sentido restrito da palavra. Porque o educar significa essa troca entre pessoas, eu acho".

Entrevistado 10: "Acho que não deveria ser. Às vezes sim, é feito desta forma, principalmente esses programas muito 
tatibitate. Mas também a escola pode ser interessante. Que tipo de escola que a gente está falando? Porque essa visão negativa que eu falei é como se eu considerasse a escola negativa. Então, não, não pode ser escola na TV. A TV tem que ser muito mais interessante! Por quê? Porque a escola pode ser interessante também! Mas eu não acho que seja escola na TV. Primeiro que você não consegue, né, em meia hora, que eu já acho grande hoje em dia um programa de meia hora, você não consegue passar todos os conteúdos necessários. Acho que é complementar".

Estes olhares apontam que a escola é viva, dinâmica, ou seja, requer movimento, transformação constante. Entretanto, todas as questões anteriores indicam que para os produtores o ensino é rígido, imutável, hierárquico. O que se percebe é que os produtores ora falam do ambiente escolar como algo vívido ora como ambiente vigoroso que enuncia um discurso monológico, conforme o modelo exógeno apresentado por Kaplún (1998), ressaltando que comumente a linguagem deste tipo de comunicação é exaustivamente analítica, racional, unidimensional.

A escola é chata, conforme dito em uma das respostas, provavelmente, porque o principal problema esteja no fato de a escola ser desconectada do cotidiano dos alunos, desconsiderando a perspectiva sócio-histórica que julga que o processo de ensino-aprendizagem também se desenvolve por meio das interações do sujeito com o meio onde está inserido.

Em sua proposta de uma pedagogia para a comunicação, Kaplún (1998) explica que no processo de comunicação educativa não basta que haja a comunicação de códigos verbais perceptivos. Para a boa codificação da mensagem é necessária uma afinidade ainda maior. É preciso que entre o emissor e o destinatário haja uma identidade de códigos empíricos, experienciais. Antes de comunicar uma mensagem, o comunicador tem de conhecer quais as experiências prévias da sua audiência. Segundo o autor, partir sempre de situações conhecidas e experimentadas pelo público. Não apenas esforçar-se para falar a mesma linguagem dos telespectadores. Mas encontrar elementos que possam servir de ponto de partida, de imagem geradora, capaz de fazer com que a audiência possa associar o novo conhecimento com situações e percepções que já tenha experimentado e vivido.

Sendo assim, mais do que nunca, a TV educativa deva contribuir para a transformação da escola e sua respectiva relação com a sociedade. 


\section{8.}

\section{Os professores encaram a TV como espaço educador?}

O resultado surpreende por tratar-se de conteúdo supostamente dirigido a comunidade escolar. Dos 10 produtores, seis disseram que não, o professor não encara a TV como um espaço educador. Dois disseram que sim. O restante não soube responder.

Os dois produtores que afirmaram que o professor encara a TV como espaço educador apontaram existir uma resistência do professorado à televisão.

Entrevistado 5: "Se não encaram, deveriam. Mas eu acho que a maioria encara. O problema é que quando a gente fala de televisão, a gente não fala em televisão educativa. A gente fala em televisão em geral, e que o professor crítico vê que é muita porcaria! Mas até pra assistir a porcaria, a gente precisa assistir pra saber o que é diferencial, o que é bom e o que é porcaria. Então o professor precisa encarar. Eu acho que a televisão tem os seus malefícios, mas eu acho que traz muito mais benefícios. A televisão tem esse caráter de apresentar o mundo pra gente e o professor tem que entender que o papel dele junto com os pais é ensinar a criança a refletir sobre o que ela está vendo, não acreditar em tudo. Aí o caráter educativo da televisão como um todo... Eu acho que nem a TV tem esse caráter, a gente é que precisa dar esse caráter pra ela. Eu acho que o papel do professor é esse, né”?

Entrevistado 6: "Agora eu acho que um pouco mais. O que há é uma rejeição, como há com outros métodos. É mais fácil chegar e colocar pra fora aquele discurso, escrever no quadro negro e estamos conversados, do que provocar os alunos a procurarem textos, filmes, chegar, mostrar e discutir".

Se para a maioria, o professor não encara a TV como um espaço educador, por que fazer televisão educativa há mais de quatro décadas?

Pelas respostas dos produtores entrevistados, o professor rechaça a TV por desconhecimento, preconceito ou falta de hábito. Porém cabe aqui sublinhar o uso crítico dos meios como aspecto fundamental do processo educativo para que a TV educativa realmente desempenhe seu papel. O que é axiomático é que a TV educa, positiva ou negativamente, isto é questão de valor, de significação de uma dada comunidade, grupo ou sujeitos. E seu poder de persuasão é tanto ou, quiçá, maior que o da escola, pois oferece um leque muito mais amplo de conteúdos e comportamentos, por muito mais horas que a escola, tendo em sua linguagem o entretenimento como poder de sedução. Kaplún (1999) coloca que tanto o programa educativo quanto um programa da TV comercial constituem fatores 
educativos, já que todos influenciam na formação de valores, pautando o comportamento público. Para o autor, todo programa educa, assim como a escola que pode educar para o bem ou para o mal. Segundo Kaplún, é perigoso ver os programas educativos como algo a parte, desconectado com a vida. Pois é desta maneira que se fragmenta a transmissão e a audiência.

\section{9 .}

Quem é o público da TV educativa?

A partir da frequência das respostas, foi possível mensurar os dados conforme o gráfico a seguir:

Figura 3 - Segmentos que compõem a audiência

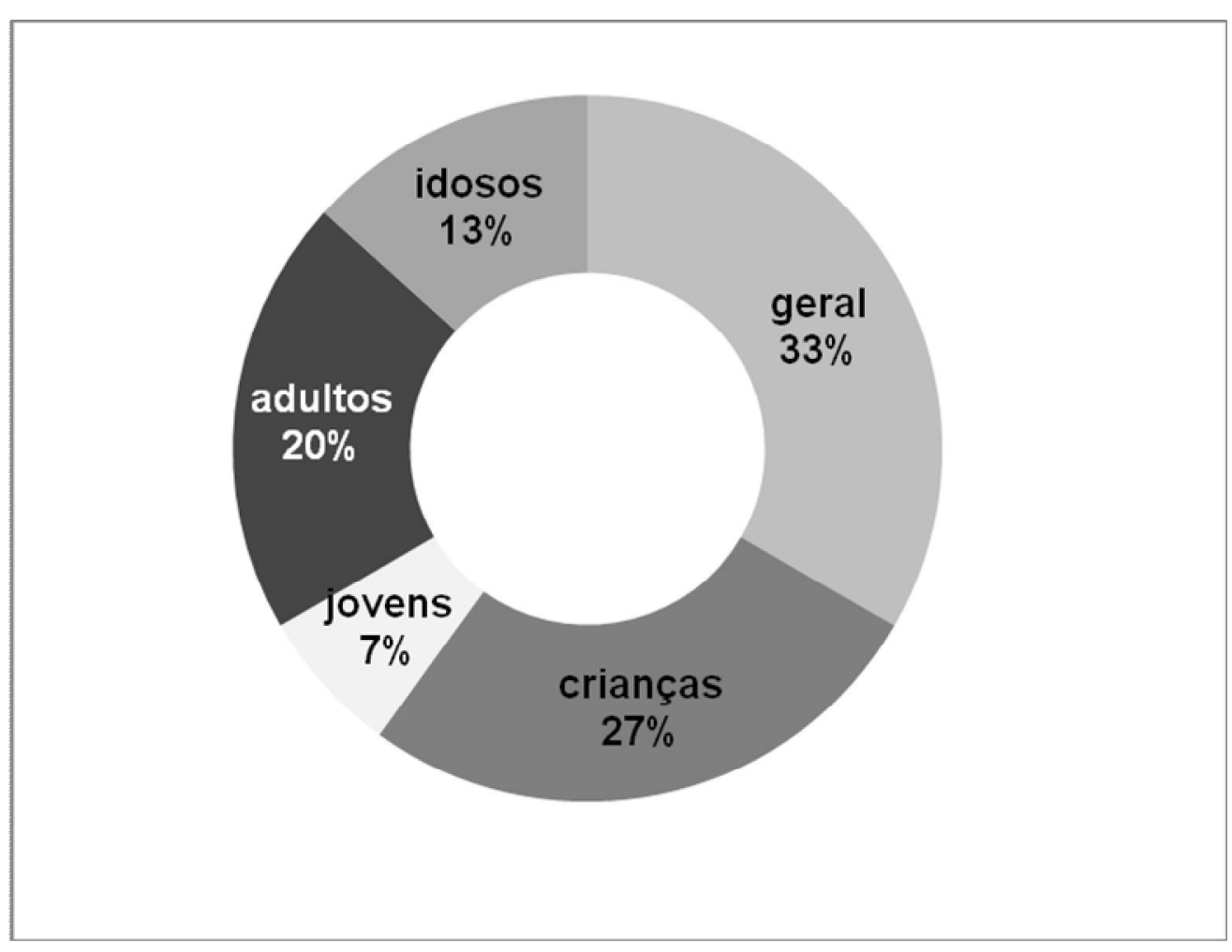

Os produtores responderam conforme as impressões a respeito do pressuposto gosto da audiência, empatia e horário de exibição. É válido frisar que não há registro na empresa de pesquisa sobre o público alvo. Os entrevistados de fato não sabem quem integra o target group, apenas supõem. A maioria das respostas variou entre adultos, incluindo idosos, e geral, composta por todas as 
faixas etárias. O critério utilizado pelos entrevistados considerou a audiência televisiva a partir da dedução de dados comportamentais do telespectador, como idade escolar e disponibilidade de tempo para assistir televisão. Os produtores entrevistados justificaram a suposição de que todas as categorias forma a audiência em virtude do argumento de que cada programa tem um público presumido: infantil-crianças; entrevista-adultos; animação-jovens e crianças; etc.

Entretanto, o gráfico revela que a hipótese de que o jovem assiste TV educativa é muito baixa, conforme as respostas atribuíram. Um produtor considera os jovens audiência, indo na contramão da maioria das respostas.

Entrevistado 1: "Acho que são crianças, jovens, acho que adultos menos e idosos. $O$ idoso, o aposentado que tem mais tempo e a criança também que tem outra relação. Até o jovem que tem um espírito de busca maior de formação. Mas eu acho que o público também é um pouco aquele que procura".

Contudo, outro produtor explica porque acredita que os jovens não têm interesse pela TV educativa.

Entrevistado 6: "Essa faixa dos adolescentes, talvez, eles se distanciem da TV educativa, justamente por isso, por ela ter o formato de escola, TV escola. Esse gap entre a criança e o adulto, que já tem autonomia pra buscar, pra fazer suas escolhas, é que eu acho que aí é que está o desinteresse. E aí eu digo desinteresse porque parece com a escola. E aí parece com a escola, não a escola que eu falei que é escola boa. Parece com aquela escola que eu não gosto. E aí se eu não gosto de escola eu não vou gostar da TV. Eu acho que tem muito disso. Agora se a coisa é legal, então, por exemplo, uma escola que tem um trabalho legal com $T V$, com produção, que tem escolas que tem isso com os adolescentes, o veículo passa a fazer parte muito mais da vida desses meninos, desses adolescentes - eu acho, e isso é um achismo mesmo, eu não tenho base pra falar sobre isso - mas o que eu vejo é isso: as escolas que trabalham com essa mídia de uma forma diferente fazem com que esse público também se interesse. Agora se a escola não está nem aí pra essa mídia e aí eu já não sei, eu acho que ela faz com que esse público se distancie”.

Esse dado revela que, desconhecendo quem é o público real da programação veiculada pela MultiRio, jovens que compõem principalmente o segundo segmento do ensino fundamental e os ensinos médio e superior não encontram espaço neste tipo de produção. Esta percepção vai de encontro com os dados apresentados na pesquisa Agenda Juventude Brasil - Pesquisa Nacional sobre 
Perfil e Opinião dos Jovens Brasileiros $2013^{57}$, realizada pela Secretaria Nacional da Juventude, com jovens entre 15 e 29 anos em todo o país. O estudo do governo federal aponta que $83 \%$ dos jovens se informam pela televisão aberta; $56 \%$, pela internet; $23 \%$, por jornais impressos; $21 \%$, por rádios comerciais; $17 \%$, pela televisão paga.

Ao não saberem ao certo identificar quem é o público da TV educativa, foi feita a pergunta se, então, o público seria o professor.

Dos 10 entrevistados, seis disseram não saber, três afirmaram que não é o professor e um declarou que sim, é o professor. Estas respostas sugerem que em uma programação classificada como educativa, muitas vezes com caráter escolar e de capacitação docente, o produto veiculado não é visto pelo professor.

Entrevistado 1: "No geral a televisão está muito ligada a essa questão de entretenimento, né? A pessoa não liga a TV pra buscar formação. É o público em geral. Não é o professor".

Entrevistado 4: "Quem assiste TV educativa é aquele (público) eventual, que coloca lá, está zapeando. E ele vê, assiste um programa que lhe interessa. Ele assiste aquele programa. Ele não migra de um programa pro outro. Ele não fica exclusivamente: ah, hoje eu vou ficar três horas, quatro, cinco horas assistindo a TV educativa! Isso nunca, eu nunca vi isso acontecer, pelo menos nesse tempo em que eu trabalho em TV educativa. [...] O professor, aо meu ver, ele assiste televisão como um veículo de entretenimento. Ele não vê a televisão, ah, vou assistir televisão... O professor passou o dia inteiro na sala de aula e chega em casa à noite, ah, agora eu vou ligar a TV educativa! Vou mais um programa aqui educativo! Eu acho que não".

Entrevistado 5: "Eu acho que não. Eu acho que o nosso problema, da MultiRio, é primeiro: a gente tem um horário muito restrito de passar na TV aberta. E esse horário o professor está na sala de aula trabalhando. A gente na Net já faz a programação noturna, eu acho que isso já amplia um pouco. Mas só pra quem tem TV a cabo. E eu não sei se o nosso público tem TV a cabo. Tem na escola! Algumas escolas devem ter. Mas em casa, não sei”.

Kaplún (1999) argumenta que o papel do comunicador não é o de colocar-se na função de fonte emissora. Já não consiste em transmitir só as suas próprias ideias. Sua ação principal é reconhecer as experiências dos destinatários, selecioná-las, ordená-las, organizá-las para, aí sim, estrutura-las e desenvolvê-las

\footnotetext{
${ }^{57}$ Secretaria Nacional de Juventude - SNJ. Agenda Juventude Brasil - Pesquisa Nacional sobre Perfil e Opinião dos Jovens Brasileiros 2013. Brasília: SNJ, novembro 2013. Disponível em: bit.ly/WIE4fe.
} 
de tal forma que os destinatários se vejam capazes de conscientemente analisá-las e refletir sobre as mensagens. O público tem se ver reconhecido naquela mensagem, tem de identificar-se com ela, ainda que não esteja participando diretamente da sua produção. O reconhecimento e a capacidade de provocar a empatia, torna de alguma maneira o receptor coautor da mensagem. Não é só refletir como num espelho. É reconhecer as experiências do público e então enunciar mensagens problematizadoras, que suscitem a reflexão, sendo esta, o que Kaplún chama de formulação pedagógica da mensagem.

Porém, quando se desconhece quem é o público destinatário, como aproximar de fato o conteúdo desta audiência? Se não se sabe para quem está falando é possível pressupor que a comunicação, todo o esforço em comunicar e educar, está falhando de alguma forma.

Este dado é um alerta emergencial para a autocrítica da televisão educativa e estímulo para repensar se a TV, de fato, é o meio mais apropriado para educar um grande público; para capacitar professores; para aproximar a escola da sociedade. Sendo afirmativa a resposta, há de se perguntar então, onde está reincidindo o erro já deflagrado por teóricos e especialistas do setor ao longo de mais de 40 anos. Caso a resposta seja negativa, há de procurar, portanto, novos meios, linguagens e tecnologias para educar um grande contingente de pessoas, com o mesmo potencial alcance da TV, mas agora, então, por outra plataforma.

\subsection{0 . Hipóteses para a baixa audiência}

Especialistas reunidos durante o simpósio internacional sobre Programação Cultural e Educativa na TV, em 1992, discutiram exaustivamente, aquilo que é conhecido de perto por quem trabalha com este tipo de programação: a baixa audiência. Entre os debatedores, Meyer (1997) resumiu que programas educativos e culturais não são aceitos pela maioria ou não são vistos por um número suficiente de pessoas interessadas por estes assuntos. $\mathrm{O}$ debate que reuniu especialistas, produtores, professores de diferentes países da Europa há mais de duas décadas, encontra motivos para continuar ativo nos dias de hoje. Head (1970) reitera que a TV educativa possui audiência extremamente reduzida. O 
público de cada programa isolado não chega a ser expresso em termos quantitativos pelos métodos convencionais, como no caso das TVs comerciais.

O "apelido" que persegue as TVs com esta finalidade é "emissora traço", que em jargão televisivo significa dizer a emissora teve entre menos de um ponto a zero ponto de audiência. A TV Brasil, antiga TVE, foi tema de reportagem da revista Época ${ }^{58}$, em 2011, que afirma conforme pesquisa do Instituto Meta, que $63 \%$ dos brasileiros nunca ouviram falar da emissora. A MultiRio não possui registros de pesquisa de audiência. A empresa baseia-se nos números registrados pela TV Bandeirantes, no Rio de Janeiro. Segundo dados apresentados pelo site Conexão $\mathrm{TV}^{59}$, a programação da MultiRio atingiu em fevereiro de 2015, a média de 1,2 pontos. Em termos comparativos, o programa Vídeo Show (exibido no mesmo horário de veiculação da programação da MultiRio) atingiu, no mesmo período, 11 pontos de audiência ${ }^{60}$.

Com base nesta discussão, foi perguntado aos produtores entrevistados qual o provável motivo de fracasso de audiência neste tipo de programação. O gráfico a seguir mostra a frequência das hipóteses levantadas pelos entrevistados como causas do insucesso de público.

58 Disponível em: http://revistaepoca.globo.com/tempo/noticia/2011/10/emissora-que-falasozinha.html. Acesso em: 03 de mar de 2015.

${ }^{59}$ Dados disponíveis em https://conexaotvaudiencia.wordpress.com/2015/02/05/. Acesso em 03 de mar 2015.

${ }^{60}$ De acordo com o Ibope, um ponto de audiência equivale a $1 \%$ do universo pesquisado, seja total de indivíduos ou total de domicílios. No Rio de Janeiro e área do Grande Rio, os números configuram 39.600 domicílios e 109.982 indivíduos na Grande Rio de Janeiro. Ou seja, os 1,2 pontos de audiência da MultiRio correspondem a 475 domicílios assistindo a programação. 
Figura 4 - Motivos apresentados para a baixa audiência

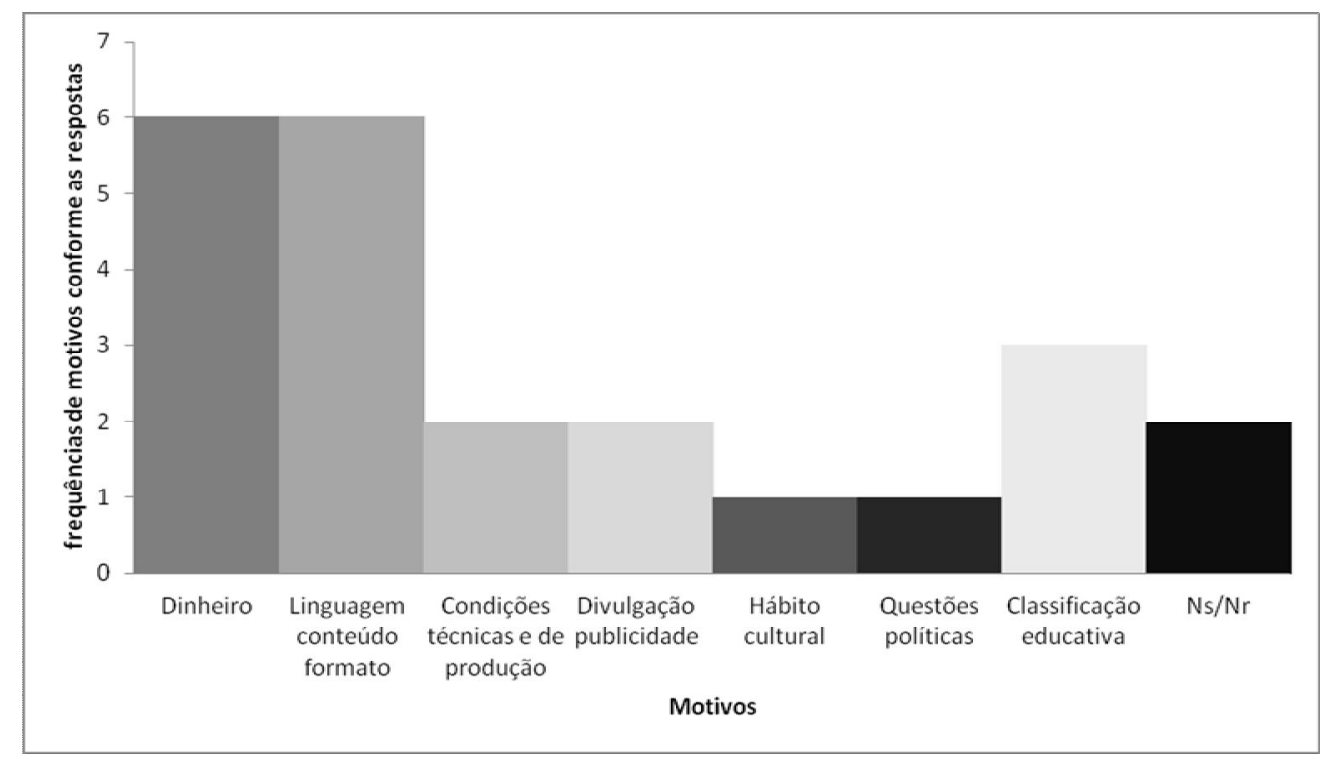

Os dois motivos mais citados foram a falta de verba para este tipo de emissora e a escolha por opções de linguagens e formatos geralmente utilizados. A classificação educativa, que rotula os produtos como tal, também seria motivo para afastar o público, seguida pelas condições técnicas e ausência de ações de divulgação da empresa. As justificativas apontam percepções interessantes de um mesmo problema.

Entrevistado 4: "Eu atribuo isso a uma questão cultural mesmo, isso é uma questão cultural, que não é uma exclusividade só daqui, uma coisa que está no mundo inteiro. Não sei se é, se são os formatos que a gente produz, se tem que haver uma mudança nos formatos, não visualizo que mudança seja essa. Não sei ao que atribuir a essa baixa audiência. Não tenho ideia ainda. Evidente que a gente ao longo desse tempo todo sabe que tem baixa audiência, a gente vê, no nosso caso, por exemplo, aqui, quando nós veiculamos uma programação na TV aberta e essa programação entra no meio de outra programação local, da programação da própria TV aberta, $e$ aí de repente a gente quebra aquela veiculação da TV aberta e entra com uma faixa de programas educativos escolares, se você pegar a audiência, você vai ver que ali tem uma queda. $O$ público do programa anterior lá da TV era um público e na hora que entra a programação educativa o público cai mesmo, e depois volta. (risos) Então eu acho que é mesmo o interesse pelo produto educativo, pelo conteúdo educativo, que é muito baixo".

Entrevistado 5: "Dinheiro. Dinheiro. Eu acho que, quando você tem patrocinadores e você tem um canal que comercializa espaços e aí você começa a fidelizar audiência, enfim, você vai 
crescendo. Eu acho que é Dinheiro. Infelizmente, é esse 'mardito' do dinheiro que faz com que a diferença da TV educativa por não ser, por não ter essa obrigação de ter vínculo, de ter audiência e depender só de recurso público, e a gente sabe que a educação está nas últimas das prioridades de qualquer governo, então como tem pouco dinheiro, não consegue fazer".

Entrevistado 7: "Eu acho que a gente peca na feitura, no fazer, a gente não faz um trabalho interessante. Não faz. E aí, por $N$ motivos. É difícil. Empresa pública é complicado, não tem as mesmas facilidades que uma empresa privada. Não tem. Mas dá pra fazer um trabalho interessante. Não é feito porque a gente vive de política. No nosso caso específico, que é a experiência que eu tenho. A gente vive de política. A gente tem gestores que são políticos, a gente tem chefias que são políticas, e não tem muito como fugir disso, mas quando na verdade, pode ser político mas que você coloque nesses cargos, e nessa gestão, que você tenha uma gestão que realmente seja compromissada com a feitura do trabalho, com a empresa. Em televisão, pra gente de televisão especificamente, é muito complicado isso porque a gente tem um tempo diferente, não só um tempo de fazer, um tempo de exibição. A gente tem um tempo de trabalho diferente, diferenciado, a gente tem uma estrutura diferenciada e você ficar preso, amarrado à estrutura pública, de uma empresa pública, é complicado, pra aquisição de equipamento, pra contratação de pessoal, então tudo isso vai emperrando um pouco o desenvolvimento".

Os motivos apresentados pelos produtores coincidem com os argumentos de especialistas do setor há mais de 40 anos. Braum et al. (1970) esclarece que o financiamento é o principal fator da baixa qualidade e do volume de serviços que a televisão educativa proporciona. $\mathrm{O}$ autor adverte que se esta barreira não for transposta a TV educativa permanecerá pífia. Porém, Head (1970) explica que a TV educativa não considera seus espectadores em termos quantitativos. De acordo com o autor, ainda que as audiências deste tipo de programação sejam baixas, parecem que são qualitativamente significativas pelo fato de tenderem a atingir a camada da população onde encontram-se os formadores de opinião.

Como explicado no capítulo 1, os parcos recursos financeiros, que obviamente vão impactar na produção de cenários, gravações, contratação de pessoal, artistas e equipamentos, acarretam também no afastamento do público considerado mais elitizado, mais escolarizado.

O financiamento público através do estado ou de colaboradores locais compromete a autonomia da emissora no que diz respeito à gestão e mais ainda, na determinação de conteúdos. O que corrobora a resposta do produtor, que 
aponta a influência política nas tomadas de decisões da empresa. Como esclarece o broadcaster Hechinger (1970): "sempre que se aceitam recursos financeiros há o perigo de algum controle" (HECHINGER, 1970, p.169).

Em síntese, a baixa audiência é consequência possível da ausência de recursos financeiros, desconhecimento sobre o público e programas desinteressantes, que geralmente espelham o modelo exógeno criticado por Kaplún, comprometendo bastante a ação educativa.

Isto posto, os entrevistados foram, então, perguntados sobre quais as prováveis razões que explicam o sucesso de produções educativas, que perduram por gerações, como Vila Sésamo, Sítio do Pica-pau Amarelo e Castelo Rá Tim Bum. Pelo gráfico, é possível acompanhar os motivos apontados com maior frequência nas respostas.

Figura 5 - Hipóteses para o sucesso de Vila Sésamo, Sítio do Pica Pau Amarelo e Castelo Rá Tim Bum

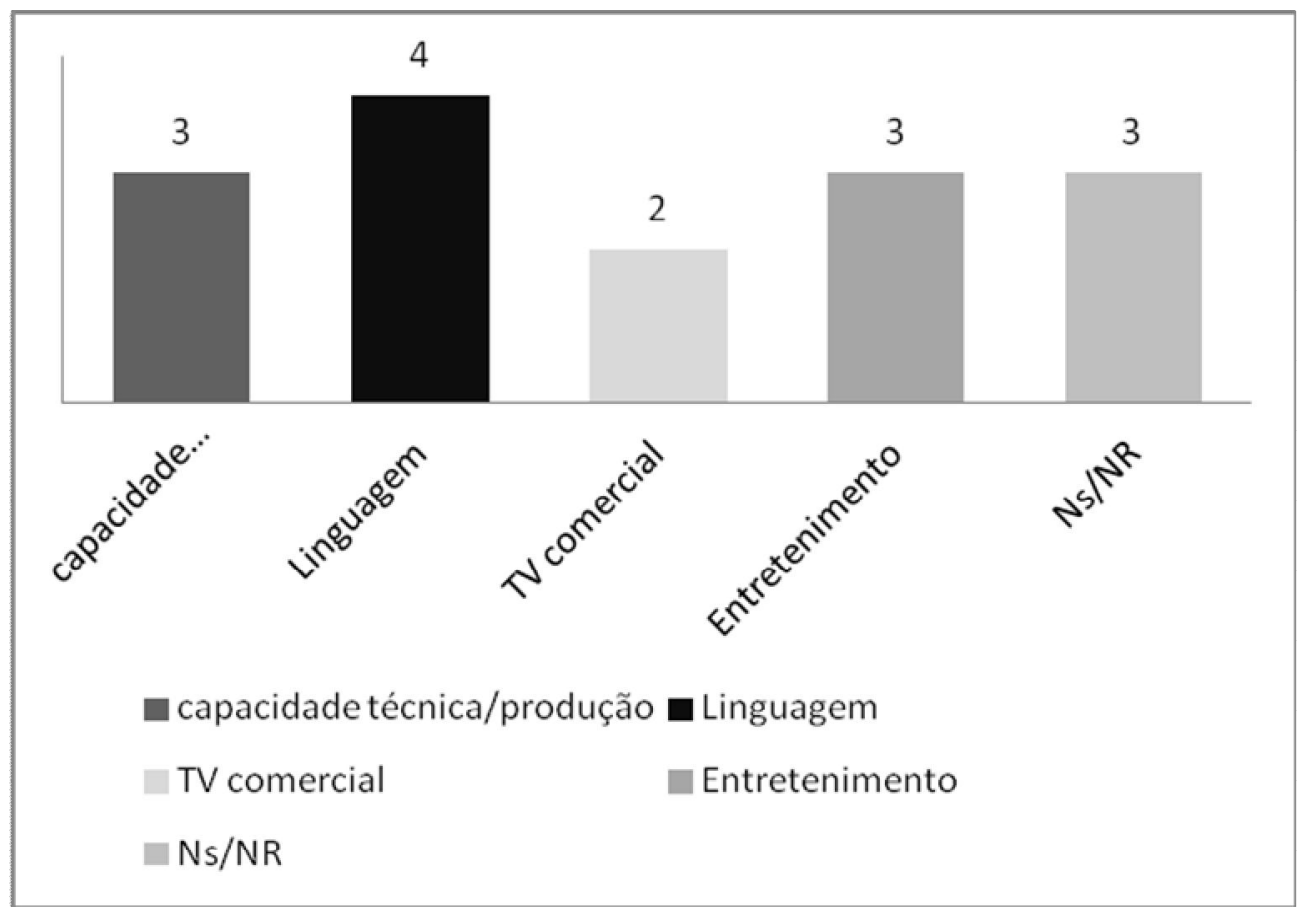

Pode-se notar que a característica linguagem foi a mais citada, seguida pela capacidade técnica de produção e pelo caráter de entretenimento. Todavia, por duas vezes, o fato de estes programas terem sido exibidos em emissoras comerciais chama a atenção para o estigma da classificação educativa, 
relacionando o sucesso à exibição em um canal sabidamente sem pretensão educativa e apelo escolar.

Entrevistado 3: "Eu acho que, por exemplo, no caso do Sítio do Pica-Pau Amarelo é a qualidade do texto que é ótima, que é literatura. A questão da forma. É muito bem produzido e isso seduz, aquela coisa da sedução. No caso do Vila Sésamo também, é a questão da linguagem. Eu acho que conseguia falar pra adultos, pra criança, para pais e filhos, eu até acrescentaria, o Cocoricó e da TV Rá Tim Bum que era um programa e hoje eles têm um canal, quase que $100 \%$ de programas educativos. Eu acho que é a qualidade do produto em si, qualidade técnica, qualidade pedagógica, qualidade no texto, qualidade na adaptação”.

Entrevistado 5: "Eu acho que o produto quando faz sucesso é porque tem espaço na mídia. O nosso Sítio do Pica-Pau Amarelo nasceu na TV educativa, mas ele explodiu na Globo. No dia em que a Globo comprou o produto e botou no ar, virou uma marca. Que foi consumida por tantos anos que teve três gerações, três ou quatro gerações de atores, principalmente as crianças. Então eu acho que isso é um reflexo do espaço. Foi pra TV Globo. O produto pode até ter nascido na TV educativa, mas ele não sobreviveu na TV educativa. Ele sobreviveu porque ele foi pra um canal de muita audiência, comercial como a Globo e a TV Tupi”.

Entrevistado 6: "O Sítio é fantástico, porque o Sítio sai de uma obra literária. Eu acho fantástico, a popularização dessa obra literária de forma tão bonita, de forma tão bem feita, com um poder educativo absurdo! Qual é a diferença disso? Eu acho que só pode ser o formato, o jeito de fazer educação, que não está escrito que é educativo. Talvez se o Sítio do Pica-Pau Amarelo não rodasse numa TV aberta, de cunho não educativo, talvez ele não tivesse tanta sustentação".

Entrevistado 7: "Eu imagino a qualidade, qualidade do programa como um todo, eu acho. Sei lá, tem que contextualizar também que geração é essa. Mas eu acho que é a qualidade. Eu acho que é a feitura. Ele é bem feito, ele é interessante, ele é cativante, ele é gostoso de assistir. E aí, não tem época pra isso. Não tem. Ele vai perder com o tempo, mas vai atravessar ainda uns bons anos aí. Eu acho que é isso. É a qualidade, é o conteúdo. É o ser gostoso de ser assistido. E aí quem é que não gosta de ver uma coisa gostosa”?

Novamente depara-se com a pertinência assumida pelos produtores em tornar prazeroso o processo de aprendizagem. Faz-se clara a importância de considerar o entretenimento valor indissociável da educação pela TV. Todavia, o que sobressai nestes dados é a anuência em considerar que a classificação educativa é fator para fracasso de audiência, brevidade de exibição e desinteresse 
do público. Com isto, mais uma vez, eclode a percepção que os produtores têm sobre a escola. O ceticismo revela que o sentido de escola pode estar carregado de traços como desânimo, fastio e desprazer.

\subsection{1 . \\ O programa educa?}

Oito entre os 10 produtores entrevistados acreditam que o programa feito por eles educa. Entre os que acreditam que sim, os motivos variaram. Contudo, a maioria explicou que o objetivo educativo é alcançado porque o programa propõe uma reflexão, traz temas relativos ao universo escolar, apresenta assuntos interessantes, conforme é possível notar nas respostas a seguir.

Entrevistado 1: "Acredito sim. Eu acho que ele tem o potencial de educar. Porque ele traz reflexão sobre algumas questões, que às vezes você vive sem pensar a respeito muito daquilo. Aquilo traz reflexão e conhecimento também".

Entrevistado 3: "Acredito. Porque me educa. Eu me sinto educado, eu me sinto aprendendo quando estou fazendo. Todo programa que eu faço eu aprendo coisas novas. E assim, é um prazer fazer. É um prazer mesmo fazer, porque eu sempre aprendo coisas novas com as coisas que eu estou editando. Então, eu acho de certa maneira, que isso é um sinal de que educa. Tem outra pessoa do outro lado lá pra assistir e aprender também".

Todavia, dois produtores entrevistados disseram que não, que seus respectivos programas não educam. A justificativa passa pelo controle na escolha da pauta e execução do produto, revelando o manejo político sobre o conteúdo.

Entrevistado 5: "Não. Eu acho que o programa que eu fazia, na fase final dele, não educava. Acho que foi apenas um programa para ficar amaciando egos e ficar acalmando, apaziguando, outros egos, entendeu? A gente se tornou uma sombra de uma proposta que a gente queria ter executado de verdade. E este, agora, é mais um programa de entrevista, com assuntos que todo mundo fala. Eu acho que não agrega não. Traz informação? Traz informação. Mas educar? Aquilo que eu falei, pra ser educativo tem que provocar uma reflexão e eu não sei se está fazendo isso. Eu acho até que, talvez, por responsabilidade minha. Ou por tantas interferências na forma em que eu trabalho. Mas o fato é que hoje, o produto que eu faço, ele é consumido. Mas a ponto de provocar uma reflexão, acho que não provoca não".

Entrevistado 7: "Não. Não. Sinceridade? As produções da MultiRio, talvez raras exceções, não servem pra nada! Elas não 
cativam! Elas podem ter conteúdo? Podem ter conteúdo. Mas elas são feitas de uma forma que não é cativante, que não é interessante, uma forma que em alguns casos não é bem feita. Elas, no meu ponto de vista, elas não conseguem segurar o telespectador. E se elas não conseguem segurar o telespectador, elas não servem pra nada. [...] Porque a gente não consegue estreitar uma parceria, estreitar uma relação com os nossos parceiros principais, que são os professores das escolas municipais do Rio! [...] $O$ nosso papel é ter uma relação íntima, intima, intima com o professor, com o aluno, com a rede. Íntima! $E$ sinceramente as nossas últimas produções... Bom, pode ser que eu seja chato também. Um programa que salva é o programa Cidade de Leitores, eu acho um programa interessante tem uma cara interessante. Mas também acho, como é que o professor vai usar aquele programa? Eu acho que pode ter na casa. Mas... A gente cumpre com ele o papel de educação mais amplo. Mas o resto, não vai. Dentro na minha visão, do nosso papel MultiRio, a gente só se afasta do objetivo. A gente só gera mais insatisfação, comentários dos professores, possibilidades de comentários de professores dizendo que a MultiRio é o pessoal que se acha. Porque a gente fica nessa coisa do político na cabeça"!

Essas duas respostas sugerem que a definição pelo conteúdo que irá ao ar passa pela determinação hierárquica, ou seja, o modelo exógeno de educação com ênfase nos conteúdos e resultados, reprovado por Kaplún (1998). Neste modelo, se estabelece uma diferença de status entre professor e aluno, comunicador e público, fomentando um comportamento mental que, segundo Kaplún, faz com que alunos e telespectadores internalizem a autoridade e superioridade do mestre. Isto não significa que este modelo não espera uma mudança de atitude do receptor ante à mensagem. Mas esta transformação não é resultado de uma ação participativa da audiência, do público alvo, no desenvolvimento do conteúdo. Esse modelo exógeno propõe que o sujeito aprenda e tome uma atitude, uma ação a partir da mensagem enunciada. Kaplún defende que a comunicação educativa valha-se do modelo endógeno, cuja premissa é fazer com que o sujeito pense. Esta atitude é resultado de um trabalho em conjunto entre comunicador e receptor, considerando no processo de produção as demandas do público, seus anseios, sua cultura, sua realidade e suas experiências. $\mathrm{O}$ enunciado é construído a partir deste diálogo. Este tipo de comunicação pedagógica estimula o desenvolvimento da consciência crítica e de uma autonomia, colaborando para que o telespectador tome consciência da própria realidade e, aí sim, ocorrer uma transformação. De 
acordo com as respostas, não há uma escuta sobre as demandas do pretenso público alvo, que na verdade, não se sabe ao certo.

Além disto, as falas evidenciam o controle do financiador, ou seja, do poder público. No caso da MultiRio, esse poder público está nas figuras da Secretaria Municipal de Educação e presidência da empresa. Verifica-se então, que a produção deste tipo de programação é repleta de nós, de tensões, que passado mais de meio século do surgimento da TV educativa, ainda permanecem e, certamente, obscurecem qualquer previsão sobre o futuro da TV educativa.

\subsection{2.}

\section{Qual o futuro da TV Educativa?}

Apesar do painel atual a cerca dos meios de comunicação desenhar uma convergência entre mídias e o espaço digital, quase todas as linguagens, cinco entre os 10 produtores entrevistados disseram não saber qual o futuro da TV educativa. Quatro seguiram a tendência da convergência, acreditando que a TV migre para a internet. Apenas um produtor disse que a TV educativa permanecerá com sua função, porém a missão educativa deixará de ser restrita ao conteúdo curricular escolar, assumindo definitivamente seu caráter cultural.

Entrevistado 4: Eu acho que a TV educativa ela vai existir sempre. Enquanto tiver TV, vai existir a TV educativa. Se você vir a TV educativa como não estritamente escolar, né? $O$ produto pode ser informativo, cultural, entretenimento e ser educativo também! Eu acredito que a TV educativa vai ser, $e$ ela já está deixando de ser, como era no início, estritamente educativa. [...] Talvez mude o perfil. O perfil do segmento. Eu acho que no futuro, ela vai ter o segmento diversificado. Não é um segmento só pra quem quer aprender na escola, pra quem quer assistir aula ou pra quem quer só informação educativa. Ela vai ter que diversificar. Criar produtos culturais, educativos, informativos e de entretenimento, mas ela vai continuar sendo a TV educativa".

Jelley (1997) observa que os avanços no campo tecnológico acarretou em um rápido crescimento no número de canais de TV que envolvem as questões educativas, como por exemplo, o Discovery Channel. Há audiência nestes canais que por sua vez precisam manter a grade completa e diversificada de programas cuja base é educativa. O desenvolvimento da tecnologia ainda não tornou realidade a interatividade na televisão. Mas este é o princípio que, segundo Jelley, pode aproximar ainda mais o espectador de informações relevantes, novos 
conhecimentos e permitir o acesso a escolas e universidades numa rede de informação e formação sem precedentes, permitindo acessar online produções de vários países que de alguma forma, se comuniquem com o conteúdo.

Entretanto, para a metade de nossos entrevistados, o futuro da TV educativa é incerto, sugerindo que tensões do passado ainda se arrastam pelo presente, e os avanços nas discussões sobre o papel da escola e da TV ainda não foram resolvidos. 


\section{6. Discussões e conclusão}

O estudo mostra que a produção de conteúdo para a TV educativa é um processo intrincado, apesar dos esforços de quem realiza este tipo de programação. Os problemas enfrentados variam dos parcos recursos despendidos para emissoras com esta finalidade até a compreensão sobre o que é educar pela TV. A concepção do que é conteúdo educativo, portanto, deriva da subjetividade destes profissionais. E, ainda que pensado em entreter e promover reflexão, as condições de produção nem sempre permitem que o resultado que vai ao ar corresponda a este anseio, representando muitas vezes um modelo de educação verticalizada, sem interlocução entre aluno e professor e/ou produtor e audiência.

Para sedimentar a análise foi preciso examinar em teóricos e especialistas questões que, em sua maioria, ainda demonstram não ter encontrado respostas significativas.

Em especialistas em broadcasting educativo como Ballaude, Braum et al., Hall, Hartford Gunn, Head, Hechinger, Jelley, Meyer, Quinn, Seldes buscou-se o valor da experiência em TV educativa, condição vital para compreender que os atuais modos de gestão, produção e concepção deste tipo de emissora e programação pouco avançaram ao longo de quase meio século de existência.

Com Harold Lasswell, Jesús Martín-Barbero, Pierre Bourdieu e Marshall McLuhan compreendeu-se a essência do meio TV e como esta se vincula com seus agentes construtores, conteúdo e a audiência.

Em Guillermo Orozco Gómez, Augustín García Matilla, Rosa Maria Bueno Fischer compreendeu-se que educação e comunicação são áreas coexistentes e que precisam ser intensamente relacionadas para a eficácia e sucesso da atividade educativa em TV.

Com Mario Kaplún, observou-se que uma programação libertária é capaz de provocar reflexão e gerar autonomia na audiência. Aliás, o autor esclarece que é preciso saber com quem se fala, saber de suas demandas e construir com este público o conteúdo que, seguramente, vai motivar a audiência. Motivação esta que configura-se qualidade necessária para a aprendizagem. 
À luz destes fundamentos, pode-se verificar-se que a televisão educativa, apesar de seu quase meio século de existência, ainda não apercebe-se. Esta consideração é reforçada pelos resultados encontrados no estudo de caso com os produtores da MultiRio.

\section{1.}

Produção subjetiva hierarquizada e pouco colaborativa

Pelos dados analisados, pode-se inferir que a produção de conteúdo educativo é resultado de escolhas feitas pelos próprios produtores, deixando de lado a teoria colaborativa de construção da mensagem proposta por Kaplún (1999). Evidencia-se que este discernimento sobre o que é ou não conteúdo educativo, o que vale ser tratado na TV, origina-se de critérios subjetivos do pessoal de produção. A determinação - no caso do grupo pesquisado, parte da Secretaria Municipal de Educação e/ou dos diretores da empresa. Não há dúvida de que os professores que demandam este conteúdo são especialistas na área, circunstância lógica deste sistema. Reconhece-se a coerência e importância desta orientação, como bem mencionou Braum et al. (1970) de que há de se depender imprescindivelmente da diretriz de professores quanto à determinação de conteúdo, formas de apresentação e utilização, pois afinal, são experimentados na ação e efeito de educar, capazes de avaliar e propor objetivos indispensáveis quanto à construção do conhecimento.

Todavia, o que foi possível depreender a partir da análise dos dados é que o processo de construção do conhecimento neste tipo de produção televisiva acaba por ser hierarquizado, caracterizando e - possivelmente evidenciando para além do set de gravação - o modelo exógeno de educação condenado por Kaplún (1999). Dentro deste modo de produção e consequente elaboração do conteúdo, o receptor constitui-se apenas receptáculo desta mensagem e não coautor do processo, cogerador, coprodutor deste conteúdo. O objetivo identificado em muitas das respostas dos entrevistados reside em levar conhecimento e provocar uma reflexão sobre o mesmo.

Kaplún $(1996 ; 1999)$ critica esta ênfase no conteúdo - o modelo exógeno onde a audiência é receptora do conteúdo transmitido pelo programa. Em consequência ao estímulo, surgiria então no receptor a reflexão sobre o assunto apresentado. O próprio autor, em seus estudos sobre a televisão, vai questionar 
esta percepção conteudista: o que ocorre de fato ante ao televisor? Segundo sua análise, existem modos de recepção que não passam pelo prazer gratificante ${ }^{61} \mathrm{e}$ nem pela intensa atividade simbólica, que leva ao telespectador codificar a mensagem e atribuir alguma significação. Para Kaplún, nem sempre assistir televisão é um ato significativo, consistente, portanto, em receber e decodificar significados. O consumo de bens simbólicos depende de onde o sujeito está situado social e culturalmente, inscrito num contexto que interfere nas maneiras de recepção.

No caso dos produtores oriundos do próprio sistema de ensino ou habituados a criar este tipo de conteúdo como suporte midiático de política pública de educação, incorre-se no risco de deturpar a empatia, conotação válida e importante do comunicador quando sucede da mesma classe social ou profissional de seus destinatários. Kaplún (1999) alerta com sua práxis de comunicador que quando no processo chega-se a assumir um certo papel de dirigentes ou apresentador já não há tendência a pensar e sentir igual a audiência. Segue-se unido, certamente no compartilhar e no compromisso. Mas adquiri-se outra percepção, outra visão. "Passa-se a falar de coisas de nossa convicção, da nossa experiência, não da experiência e expectativa dos destinatários", ressalta o autor. (KAPLÚN, 1999, p.100).

Kaplún (1998) defende a pedagogia que estimula a autonomia do educando. Nesta proposta, o desejo é alcançar uma mudança de atitude, de um sujeito acrítico para um sujeito crítico, transpondo tendências individualistas para valores solidários e comunitários. Segundo o autor, o educando não necessita tanto dos dados e conteúdos quanto de ter exercitada sua capacidade de perceber o seu entorno. Para Kaplún, só há verdadeiramente aprendizagem quando há processo, quando há autonomia dos educandos. E isto é conquistado pelo grupo, cujo papel do professor é mediar esta aprendizagem. O professor estimula, facilita o processo

${ }^{61} \mathrm{O}$ autor coloca que os estudos sobre audiência foram embasados por duas correntes ao longo das últimas quatro décadas. Até os anos de 1970, a análise crítica, de cunho estruturalista, considerou as estruturas econômicas e políticas de poder, suas mensagens, metamensagens e ideologias como forma de manipulação. Para explicar o consumo massivo dos meios, recorreu-se a imagens robóticas tais como alienação, imposição e anestesiamento. Nesta concepção, o público é inerte às mensagens, aos meios, constituindo-se um objeto passivo, indefeso. Em resposta a essa visão mecanicista, advieram novos paradigmas com ênfase na revindicação do receptor, que agora passa a ser sujeito interatuante. Da imposição, a lógica passa a ser a da aliança. Ou seja, se a televisão conquista tanta audiência é porque esta oferece mensagens que coincidem com as necessidades simbólicas e gostos sociais, resultando numa recepção autenticamente gratificante (KAPLÚN, 1996). 
de busca, problematiza, escuta para ajudar que o grupo se expresse, avançando no processo. A educação é processo permanente, não se limitando a uns momentos da vida. A comunicação educativa, admitida pelo autor, rechaça a ideia de hierarquia entre educadores e educandos; na relação entre professores e estudantes - e neste caso, televisão e audiência - importando, sim, o exercício da atitude crítica frente ao objeto e não ao discurso do educador em torno do objeto. Ou seja, é preciso ler, ouvir, interpretar televisão e não apenas receber o que é passado como conteúdo educativo definido e percebido como tal, simplesmente porque está veiculado numa programação previamente classificada com este objetivo. Desta forma, ainda hoje, verifica-se que produz-se conteúdo educativo de forma exógena, pressupondo uma audiência e uma aprendizagem desta.

\section{2. \\ Audiência desconhecida e (portanto) inalcançada}

$\mathrm{O}$ estudo mostrou, ainda, que a TV educativa corre o risco de falar para ninguém ouvir. As respostas dos produtores pesquisados atestaram que desconhece-se quais grupos compõem de fato a audiência da TV educativa. Destaque para a incerteza de que o professor faz parte desta audiência efetivamente. Logo, a TV educativa pode estar falhando no propósito de capacitar e oferecer ao professorado subsídios para suas atividades escolares, descumprindo um de seus objetivos natos, além de desperdiçar recursos. Com o fim de realizar uma comunicação educativa, Kaplún (1999) explica que é preciso saber as necessidades da comunidade, do público, para então conseguir construir juntos a mensagem. O que quero dizer, a quem vou dizer, orienta Kaplún aos comunicadores educativos. Em sua pedagogia para a comunicação, o autor afirma que tão necessário quanto saber o que queremos dizer é saber o que os nossos destinatários esperam escutar e ver na TV, a partir da busca de convergência, de encontro. Para o autor, a verdadeira comunicação não se começa falando e sim escutando. $\mathrm{O}$ autor ainda alerta que nossos destinatários têm seus interesses, suas preocupações, suas necessidades, suas expectativas e está esperando que falemos das coisas que lhes interessam, não das que nos interessam. Entretanto, como realizar este tipo de diálogo se desconhece-se quem é o público?

Fischer (2001) revalida a necessidade de identificar-se o público para garantir que haja interação neste processo educativo. A autora defende que 
qualquer análise sobre televisão, suas formas, linguagens, peculiaridades, terá de considerar o conjunto do processo comunicativo, a situação específica de produção e veiculação, questões políticas e culturais. Porém, primordialmente, deve-se examinar o público a qual se dirige as mensagens. Fischer esclarece que a escolha dos textos, das imagens, dos sons, do tempo, formatos e distribuição dos programas na grade de programação existe em função de alguém que se espera que seja "x" ou "y". Pelas respostas dos produtores apresentadas neste estudo, as hipóteses de quem é o público são logicamente acrescidas do fato da natureza da empresa ser destinada à comunidade escolar. Mas não há certeza sobre a identidade da audiência da programação.

\section{3.}

\section{O conceito de cultura como apropriação social}

Observou-se, ainda, que a maioria dos produtores disse acreditar estar educando de alguma forma o telespectador com seus programas. Temas culturais seguindo a percepção sócio-histórica foram considerados mais cativantes e apropriados, reconhecendo assuntos desta natureza como conteúdo educativo, evidenciando que o processo de aprendizagem ocorre em outras instâncias para além da escola. Notou-se, também, que o modelo instrucional teleaula foi considerado ultrapassado e desinteressante. Todavia, o mesmo foi admitido como um formato apropriado para a televisão, o que demonstra uma incongruência e insinua que o modelo formal tradicional de ensino acaba por prevalecer no momento de criação e produção dos programas, mesmo que haja anseio de romper este paradigma. A resistência ao modelo formal de ensino e a busca por quebrar com este padrão pode ser notada, talvez, pelo interesse, principalmente dos profissionais de comunicação, em aproximar-se da literatura educacional cujos pensadores estão alinhados à perspectiva histórico-culturais, relatados na busca pela compreensão da área correlata.

A sala de aula e o espaço da TV são representações sociais. Em ambos podemos ver o desenvolver de personagens e ações que replicam comportamentos fora dos muros escolares e à frente da tela. Neste jogo de papéis desempenhados pelos atores da ação (no sentido literal ou não) é possível reconstruir as regras e as normas existentes entre as pessoas, nas situações da vida, através de situações simbólicas. Do lado de fora da escola e da TV, alunos e telespectadores 
experimentam um aprendizado em rede, coletivo e colaborativo por meio das mídias sociais. Experiência de aprendizagem, inclusive entre adultos, que nos remete à perspectiva histórico-cultural, permitindo que audiência e estudantes construam seu próprio conhecimento.

\section{4 .}

\section{Visões diferentes de TV Educativa, entre forma e conteúdo}

É nítida, a todo instante, a existência de uma oposição binária entre conteúdo e forma. $\mathrm{O}$ entendimento de que é possível educar sem evidenciar explicitamente o propósito educativo numa programação, configurando a existência de outras pedagogias e meios de educar, é contemplado por Kaplún (2001) no raciocínio de que, além de educação formal e não formal ${ }^{62}$, existe uma terceira categoria: a informal, que não vê a educação como o simples resultado de ações mais ou menos ligadas ao sistema escolar prescritivo, mas como a soma de todos os estímulos sociais, incluindo mensagens midiáticas, que atualmente ocupam um lugar central no dia a dia da sociedade. É nesta dimensão que verificase, de forma mais acentuada, os esforços educacionais feitos por meio dos veículos de comunicação. Neste modo, já não existe um educando a quem se anuncia e explicita claramente a intenção de oferecer-lhe educação e que, por sua vez, coloca-se expressamente na atitude de recebê-la. Não exige-se do receptor a intencionalidade, a vontade consciente de aprender. $\mathrm{O}$ telespectador recebe espontaneamente a mensagem, porque ele está interessado, porque a mensagem foi capaz de captar a atenção e mobilizar a resposta da audiência. Em outras palavras, porque esta mensagem foi, por assim dizer, "competitiva" em relação a outras ofertadas ao consumo do público.

Segundo os resultados, a predileção por gêneros classificados como entretenimento trouxe à superfície um dos principais aguilhões que caracteriza o debate sobre TV educativa: a aceitação do entretenimento, do prazer, como parte indissociável do processo de aprendizagem. Principalmente pela TV. Mesmo considerando que conteúdo educativo em televisão é entretenimento, os produtores entrevistados reconheceram que os programas deste tipo são

${ }^{62}$ Kaplún entende por educação formal a educação tradicional restrita a espaços formais de educação, como a escola. Não formal, a educação oriunda de meios e espaços populares, sociais e culturais, resultado da troca entre os indivíduos, baseada numa matriz de educação popular freireana. 
delimitados por uma extenuante preocupação em dar conta de todos os aspectos e informações inerentes ao assunto tratado, demonstrando a consumação do modelo exógeno tão criticado por Kaplún (1998). O autor afirma que a comunicação educativa deve ser rica e variada, valendo-se de muitas linguagens, abrindo as comportas para a criatividade e a imaginação. Entretanto, ressalva que enquanto a comunicação educativa reproduzir a hierarquia da escola tradicional, onde o poder de enunciar cabe ao professor exclusivamente, vamos ter na televisão ou no rádio a imagem refletida deste tipo de educação, e certamente uma programação enfadonha pois afinal, anseia-se que a TV educativa na TV.

O conflito forma e conteúdo talvez reflita a tensão existente no convívio entre estas duas áreas do saber: educação e comunicação neste tipo de programação. O estudo de campo descortinou o atrito entre os profissionais destas duas áreas que trabalham em conjunto. A causa principal deste desentendimento apontada pelos produtores pesquisados é a falta de conhecimento de uma área sobre a outra e vice-versa. Comunicadores não especializados em educação e educadores sem intimidade com os meios.

Fischer (2001) explica que a linguagem audiovisual requer uma experiência sensorial. Tentar compreendê-la, primeiramente, por uma abordagem intelectual é um equívoco. A autora esclarece que pela própria natureza desta linguagem, é preciso percebê-la através dos sentidos e emoções para, então, poder depois pensar sobre ela, analisá-la, interpretá-la. É neste aspecto que resida, provavelmente, boa parte das dificuldades de professores e educadores. Em plena era tecnológica e multimídia, a formação escolar e acadêmica ocorre quase exclusivamente verbal, conceitual, linear. A alfabetização para as sensações, emoções e sentimentos não é ministrada nos cursos de graduação.

Se desconhece-se o objetivo educativo por não dominar a área da educação e também como expressar-se em toda a potencialidade da televisão, provavelmente, o uso deste meio corre o risco de tornar-se apenas um instrumental, um suporte técnico a uma aula. Head (1970) afirma que quando uma emissora de TV educativa é empregada simplesmente para retransmitir programas para as escolas, não está cumprindo o seu papel de televisão. O mesmo fim poderia ser atingido por outros métodos, sem despender tantos recursos financeiros e de pessoal. E enfatiza que na medida em que estas emissoras são 
utilizadas com essa finalidade, não faz sentido avaliar suas programações do ponto de vista da televisão.

\section{5 .}

\section{Fazer TV com recursos limitados}

A falta de recursos também foi apontada como entrave ao sucesso efetivo da TV educativa, ligada a financiamento público estatal ou civil. Condição, que segundo a discussão apresentada neste estudo e apontada pelos produtores pesquisados, determina a linha editorial da programação, podendo caracterizar-se em dadas circunstâncias como agente complicador na manutenção e produção deste tipo de programação.

Dentro destes resultados, tornou-se evidente com este estudo que o elemento principal que permeia toda a discussão sobre TV educativa e educação na TV é, na verdade, a concepção de escola que estes produtores têm. Tanto os educadores quanto os comunicadores.

Pelas respostas, foi possível perceber que talvez a escola seja percebida como um espaço monocórdio, apontando para a urgente transformação da relação de ensino e do papel que a instituição desempenha na sociedade. A começar, por aceitar em seus currículos básicos a formação para os meios, contribuindo para a construção de uma audiência crítica e autônoma. Kaplún (1998) pondera que a concepção comunicacional e educativa unidirecional aparece como uma corrente natural, sem que sejamos conscientes disto, seguindo influenciando com força nossos agir e pensar.

A compreensão de que a TV educativa tem que ser o oposto da TV comercial, porque esta última não tem o propósito primeiro de educar, nega a possibilidade de o público educar-se por outros modos que não a escola. E isto pode ser desastrosa à sobrevivência da TV educativa, distanciando-a do grande público. $\mathrm{O}$ entendimento de que a TV educativa está a serviço da escola apenas pode ter o mesmo efeito danoso, pois "lecionar" para a comunidade escolar somente significa negligenciar a sua responsabilidade social de educar aqueles que por múltiplos fatores não se identificam com o campo escolar. Estas questões devem ser repensadas, ficando abetas para futuras pesquisas.

E se o presente ainda não cicatrizou chagas de mais de quatro décadas, que o futuro da TV educativa apresenta-se como incógnita para os produtores 
entrevistados, mesmo que a migração para o universo digital e internet tenham sido os caminhos apontados, sugerindo a convergência entre mídias ${ }^{63}$. No entanto, os produtores não souberam informar a velocidade desta migração e quais transformações ocorrerão no processo produtivo, impactando na forma e no conteúdo dos programas.

Esta pesquisa não pretendeu somente investigar as questões que permeiam a produção de programas para TV educativa. Desejou-se sugerir a autocrítica como via possível para buscar soluções para problemas aqui evidenciados. O estudo apresentado buscou contribuir para o conhecimento e compreensão deste tipo de educação presente em diversos países e, certamente, tão importante para a formação da sociedade. A investigação propôs-se pensar sobre as questões apresentadas, permitindo discutir as atribuições e contribuições desta programação, ajudando a repensar técnicas, linguagem, uso, objetivos, valores e relações que compõem o desafio diário de produzir produto educativo em TV. Ante a escassez de teorias no campo da TV educativa, modelos observados como o da MultiRio no estudo de campo ajudam a conceituar e visualizar os processos de comunicação e aprendizagem, tornando-se útil no aperfeiçoamento e construção de teorias a respeito do assunto.

A TV educativa representa a possibilidade de, não somente compensar deficiências e melhorar o sistema público de ensino através de suas transmissões, como, também, significa a oportunidade de construir uma aprendizagem efetivamente educativa e cultural de amplo alcance.

Para tanto, é preciso reavaliar o uso da TV no processo educativo e a forma com vem sendo utilizada. Pensar em como os telespectadores, ante às atuais plataformas digitais de comunicação, se relacionam com o meio. Para que serve? Onde é vista? Como é vista? Quem assiste? Com que outra plataforma converge? A tela que antes nos deixava imóveis frente a ela, agora compete com várias outras telas móveis. Qual é o espaço que damos atualmente à TV? Repensar que o meio televisão, não dialógico, está agora imerso num contexto tecnológico onde interação parece ser a condição básica de sobrevivência.

\footnotetext{
${ }^{63}$ Henry Jenkins (2009) explica que cultura da convergência é o fluxo de conteúdos através de múltiplas plataformas de mídia. É a cooperação entre os múltiplos mercados midiáticos e também o comportamento migratório dos públicos dos meios de comunicação, que vão a quase qualquer parte em busca das experiências de entretenimento que desejam. "Convergência é uma palavra que consegue definir transformações tecnológicas, mercadológicas, culturais e sociais, dependendo de quem está falando e do que imaginam estar falando" (JENKINS, 2009, p. 29).
} 
Desta forma, faz-se necessário admitir que a escola tem de escancarar as portas de suas salas e de seu fazer à inevitável compreensão da linguagem dos meios. Não usá-los como suportes, substituindo o quadro negro pela lousa digital. Mas entender que o sucesso atual de plataformas, como games e vídeos entre alunos de todos os níveis, evidencia o que a TV já sinalizava: a aprendizagem pode e deve ser feita por meio de uma linguagem sensorial, que aguça os sentidos, motiva e desperta o interesse para a construção de um conhecimento em conjunto, lúdico, onde todos são educadores e educandos. Não que o professor torne-se a figura do apresentador ou animador de auditório. Esta é a TV velha, ultrapassada que ainda tenta plasmar-se ao cenário atual, reproduzindo fórmulas passadas. $\mathrm{E}$ este também não é o papel do professor, do qual, talvez, espera-se hoje, medeie à aprendizagem como algo que se constrói de forma coletiva, cooperativa, colaborativa e organizada, caracterizado como uma atividade pedagógica social.

É necessário que profissionais de televisão e de educação se esforcem para acompanhar os avanços tecnológicos e as mudanças de comportamento que esta imensa possibilidade de comunicar provocou em nossa sociedade. Agora mais do que nunca é saber quem eu sou e o que quero. Não dá mais para ignorar quem é minha audiência e para que sirvo, como sirvo. Não dá mais para ignorar quem é meu aluno e do que servem minhas aulas. Não dá mais para pressupor quem é minha audiência.

O enfrentamento provocado pelo olhar para si pode ajudar a fechar as feridas de décadas da TV educativa e dar força para ir adiante. Dentro e fora da tela, na construção de uma efetiva comunicação educativa. 


\section{7. Referências bibliográficas}

ABREU, K. C. K, SILVA, R. S. História e Tecnologias da Televisão. Bagé: Unipampa. 2012. Disponível em: http://www.bocc.ubi.pt/pag/abreu-silva-historiae-tecnologias-da-televisao.pdf. Acesso em: 22 jun. 2014.

AGUiAR, R. C. Almanaque da Rádio Nacional. Rio de Janeiro: Casa da Palavra, 2007.

ALVES, R. A complicada arte de ver. Folha de São Paulo, 26 out. 2004. Disponível em: http://www1.folha.uol.com.br/folha/sinapse/ult1063u947.shtml. Acesso em: 27 nov. 2014.

ALVES, V. TV Tupi, uma linda história de amor. São Paulo: Imprensa Oficial, 2008 . Disponível em: http://aplauso.imprensaoficial.com.br/edicoes/12.0.813.418/12.0.813.418.pdf. Acesso em: 12 nov. 2014.

AMADO, G. A televisão educativa no Brasil. Conferência da Comissão de Educação e Cultura do Senado. Revista de informação legislativa, Brasília, p. 13-50, $1971 . \quad$ Disponível em: http://www2.senado.leg.br/bdsf/bitstream/handle/id/180456/000340194.pdf?seque nce $=1$. Acesso em: 12 out. 2014 .

ARCA DE NOÉ. Vinícios para criança. Rio de Janeiro: TV Globo. Memória Globo. Disponível em: http://memoriaglobo.globo.com/programas/entretenimento/infantojuvenis/vinicius -para-crianca-a-arca-de-noe/formato.htm. Acesso em: 15 jan. 2015.

ARONCHI DE SOUZA, José Carlos. Gêneros e Formatos na Televisão Brasileira. São Paulo: Summus, 2004.

ASHEIM, L.; BRISH, W.; BRONSON, V. Educação pela TV : estudo dos problemas e pesquisas sobre as potencialidades da televisão educativa. In: NETO, T. N. (Org.). Educational television the next ten years. Rio de Janeiro: Bloch, 1970.

BAUMWORCEL, A. As escolas radiofônicas do MEB. In: VI Congresso de História da Mídia, maio, 2008, UFF, Niterói. Disponível em: http://www.ufrgs.br/alcar/encontros-nacionais-1/encontros-nacionais/6o-encontro2008-1/As\%20escolas\%20radiofonicas\%20do\%20MEB.pdf. Acesso em: 12 jun. 2013.

BBC. History of the BBC - 1930s. Disponível em: http://www.bbc.co.uk/timelines/zqbfyrd. Acesso em: 14 jul. 2014.

BELLONI, M. L. O que é mídia-educação. Campinas: Autores Associados, 2001.

BOURDIEU, P. (Coord.) A miséria do mundo. Petrópolis: Vozes, 2008.

BOURDIEU, P. Sobre a televisão: seguido de, A influência do jornalismo; e, Os Jogos Olímpicos. Rio de Janeiro: Zahar, 1997.

BRAUM ET AL. Uma política nacional de televisão educativa. In: NETO, T. N. (Org.). Educational television the next ten years. Rio de Janeiro: Bloch, 1970.

BROADCAST NEWS AM FM TELEVISION. New Jersey, USA: RCA, n. 46, set. 1947. Disponível em: http://www.americanradiohistory.com/Archive-RCABroadcast-News/RCA-46.pdf. Acesso em: 25 ago. 2014. 
BULLAUDE, J. Televisión educativa em América Latina: problemas y perspectivas. In: KOENING, A.E., HILL, R. B. TV educativa: presente y future. Buenos Aires: Troquel, 1970.

BRASÍLIA. Portaria interministerial $\mathrm{n}^{\circ} 651$, de 15 de abril de 1999. Os ministérios da Educação e das Comunicações estabelecem critérios para outorgas de concessões, permissões e autorizações para execução dos serviços de radiodifusão imagens, com finalidade exclusivamente educativa. Ministério da Educação. Brasília. Disponível em: http://www.mc.gov.br/index.php?option=com_mtree\&task=att_download\&link_i d=127\&cf_id=24. Acesso em: 04 jul. 2013.

BUCKInGHAM, D. Children Talking Television: The Making of Television Literacy. London: Falmer Press, 1993.

BUCKINGHAM, D.; SCANLON, M. Selling Learning: Towards a Political Economy of Edutainment Media. Media, Culture and Society, London, n. 1, $2005 . \quad$ Disponível em: http://www.dragnetsystems.co.uk/cscym/Pics/Political\%20Economy_db.pdf.

CANCLINI, N. G. Consumidores e cidadãos: conflitos multiculturais da globalização. Rio de Janeiro: UFRJ, 2010.

CANCLINI, N. G. Leitores, espectadores e internautas. São Paulo: Iluminuras: Itaú Cultural, 2008.

CARPENTER, E.; MCLUHAN, M. Revolução na Comunicação. Rio de Janeiro: Zahar, 1974.

CLARK, W., PRIOLli, G. O campeão de audiência. São Paulo: Best Seller, 1991.

COSTA, P. C. Educadores do rádio: concepção, realização e recepção de programas educacionais radiofônicos (1935-1950). São Paulo, 2012. 272 p. Tese (especialização em Educação) Faculdade de Educação, Universidade de São Paulo.

CRAIDY, G. Meios e audiências: a emergência dos estudos de recepção no Brasil. Porto Alegre: Revista Famecos, $\mathrm{n}^{\circ}$ 38, 2009. Disponível em: http://revistaseletronicas.pucrs.br/scientiamedica/ojs/index.php/revistafamecos/art icle/view/5312/3887. Acesso em: 25 maio 2013.

CURADO, O. A notícia na TV, o dia a dia de quem faz telejornalismo. São Paulo: Alegro, 2002.

DECRETO-LEI $\mathrm{N}^{\mathrm{o}}$ 236, de 28 de fevereiro de 1967. Disponível em: http://www.planalto.gov.br/ccivil_03/decreto-lei/del0236.htm. Acesso em: 14 jun. 2013.

DECRETO $\mathrm{N}^{\mathrm{o}}$ 2.108, de 24 de dezembro de 1996. Disponível em: http://www.planalto.gov.br/ccivil_03/decreto/d2108.htm. Acesso em: 14 jun. 2013.

DUARTE, E. B. Televisão: ensaios metodológicos. Porto Alegre: Sulina, 2004.

DUARTE, J.; BARROS, A. (Org.). Métodos e Técnicas de Pesquisa em Comunicação. São Paulo: Atlas, 2005.

FAUSTO, B. História do Brasil. São Paulo: Editora da Universidade de São Paulo, 1995.

FÁVERO, O. MEB - Movimento de Educação de Base primeiros tempos: 1961-1966. In: V Encontro luso-brasileiro de História da Educação, abril, 2004, Évora, Portugal. Uma pedagogia da participação popular; análise da prática pedagógica do MEB - Movimento de Educação de Base, 1961-1966. Campinas: Autores Associados, 2006. 
FEDERICO, M. E. B. História da comunicação. Rádio e TV no Brasil. Petrópolis: Vozes, 1982.

FERNÁNDEZ, V. F. Programação. Por uma televisão pública para a América Latina. In: RINCÓN, O. (Org.). Televisão pública: do consumidor ao cidadão. São Paulo: Friedrich-Ebert-Stiftung, 2002.

FERREYRA, I. P. El televisor: La pantalla estrella. Huelva: Comunicar, Revista Científica de Educomunicación, n. 25, p.193-195, 2005.

FLÄCKEL, A. Bildungsfernsehen weltweit. Eine internationale Expertenbefragung. Televizion, Germany, 21 fev. 2008. International Central Institute for Youth and Educational Television (IZI). Entrevista concedida a Elke Schlote. Disponível em: http://www.bronline.de/jugend/izi/deutsch/publikation/televizion/21_2008_2/schlote_flaeckel.p df. Acesso em: 06 jun. 2014.

FLECHAS, J. C. ET AL. Aproximaciones a la Televisión Educativa. Colombia: Ministerio de Educación Nacional, 2004.

FORT, M. C. Televisão educativa: a responsabilidade pública e as preferências do espectador. São Paulo: Annablume, 2006.

FREIRE, P. Extensão ou Comunicação? Rio de Janeiro: Paz e Terra, 1974.

FREIRE, P. Pedagogia do oprimido. Rio de Janeiro: Paz e Terra, 1987.

GERHARDT, T. E.; SILVEIRA, D. T. (Org.). Métodos de pesquisa. Porto Alegre: Editora da UFRGS, 2009.

GLASER, B. G., STRAUSS, A. L. The discovery of Grounded. Theory. Strategies for qualitative research. New Jersey: Rutgers University, 1967.

GOLDENBERG, M. A arte de pesquisar. Rio de Janeiro: Record, 1997.

HALL. J. A TVE, um recurso de valor fundamental. In: NETO, T. N. (Org.).

Educational television the next ten years. Rio de Janeiro: Bloch, 1970.

HARTFORD N. GRUNN, JR. Opinião do diretor de uma emissora sobre os problemas de programação In: NETO, T. N. (Org.). Educational television the next ten years. Rio de Janeiro: Bloch, 1970.

HEAD, S. W. Um crítico cordial escreve sobre os programas de TVE. In: NETO, T. N. (Org.). Educational television the next ten years. Rio de Janeiro: Bloch, 1970.

HECHINGER, F. Depoimento prestado ao Grupo Consultivo da Televisão. In: Schramm, W. (Org.) Educação pela TV: estudo dos problemas e pesquisas sobre as potencialidades da televisão educativa. Rio de Janeiro: Bloch, 1970.

IBOPE. Conceitos e critérios de pesquisa de mídia para imprensa. São Paulo. Disponível em: http://www.ibope.com.br/ptbr/relacionamento/imprensa/Documents/cartilha_de_midia.pdf. Acesso em: 05 dez. 2014.

JACQUINOT, G. O que é o Educomunicador? São Paulo: USP, 1998.

JELLEY, C. Has international cooperation a future? In: JELLEY, C. Educational Television. What do people want? United Kingdom: University of Luton, 1997.

JENKINS, H. Cultura da convergência. São Paulo: Aleph, 2009.

KAPLÚN, M. A la educacion por la comunicación la práctica de la comunicación educativa. Quito-Ecuador: Ciespal, 2001.

KAPLÚN, M. Cultura de imagenes no de sentidos. Chasqui Revista Latinoamericana de Comunicación, Quito-Ecuador, n. 47, p. 14-17, nov. 1993. KAPLÚN, M. El comunicador popular. Quto-Ecuador: Ciespal, 1985. 
KAPLÚN, M. El entretenimiento como necesidad. Comunicación: estudios venezolanos de comunicación. Caracas: Centro Gumilla, p. 20-31, 1992. Disponível em: http://gumilla.org/biblioteca/bases/biblo/texto/COM19927778_20-31.pdf. Acesso em: 12 dez. 2014.

KAPLÚN, M. Ni impuesta ni amada: la recepción televisiva y sus tierras incógnitas. Comunicación: Estudios Venezolanos de Comunicación. Caracas: Centro Gumilla, n. 91, p. 46-55, jul/set. 1995. Disponível em: http://gumilla.org/biblioteca/bases/biblo/texto/COM199591_46-55.pdf. Acesso em: 25 set. 2014.

KAPLÚN, M. Procesos educativos y canales de comunicación. Comunicación: Estudios venezolanos de comunicación. Caracas: Centro Gumilla, n. 103, p. 1115, jul/set. $1998 . \quad$ Disponível em: http:/gumilla.org/biblioteca/bases/biblo/texto/COM1998103_11-15.pdf. Acesso em: 25 out. 2014.

KAPLÚN, M.. Producción de programas de radio, EL guión - La realización. Quito-Ecuador: Ciespal, 1999.

KAPLÚN, M. Una pedagogia de la comunicación. Madrid: Ediciones de La Torre, 1998.

KOENING, A.E.; HILL, R. B. TV educativa: presente y future. Buenos Aires: Troquel, 1970.

LAKATOS, E. M.; MARCONI, M. A. Técnicas de pesquisa: Planejamento e execução de pesquisas. Amostragens e técnicas de pesquisa. Elaboração, análise e interpretação de dados. São Paulo: Atlas, 2002.

LASSWELL, H. D. O future dos programas referentes a questões de interesse público. In: NETO, T. N. (Org.). Educational television the next ten years. Rio de Janeiro: Bloch, 1970.

LASSWELL, H. D.; KAPLAN A., Power and society. A framework for political inquiry. Connecticut: Yale University Press, 1950.

LIBÂNEO, J. C. Didática, velhos e novos temas. Goiânia: Edição Autor, 2002.

LOPES, C. A. Regulação da radiodifusão educativa. Brasília: Câmara dos Deputados, 2011. Disponível em: http://www2.camara.leg.br/documentos-epesquisa/publicacoes/estnottec/tema4/2011_63.pdf. Acesso em: 11 nov. 2013.

LUNA, S. V. Planejamento de pesquisa: uma introdução. São Paulo: Educ, 2011.

MACHADO, A. A televisão levada a sério. São Paulo: SENAC, 2001.

MATTELART, A.; MATTELART, M. História das teorias da comunicação. São Paulo: Loyola, 2008.

MATILLA, A. G. Uma televisón para La educación: La utopia posible. Barcelona: Gedisa, 2003.

MARTÍN-BARBERO, J. Dos meios às mediações: comunicação, cultura e hegemonia. Rio de Janeiro: UFRJ, 2006.

MARTÍN-BARBERO, J.; REY, G.. Os exercícios do ver: hegemonia audiovisual e ficção televisiva. São Paulo: SENAC, 2001.

MARTÍN-BARBERO, J. Televisão pública, televisão cultural: entre a renovação e a invenção. In: RINCÓN, O. (Org.) Televisão pública: do consumidor ao cidadão. São Paulo: Friedrich-Ebert-Stiftung, 2002.

MCLUHAN, M. Os meios de comunicação como extensões do homem. São Paulo: Cultrix, 1969.

MEYER, M. Educational Television. What do people want? United Kingdom: University of Luton, 1997. 
MILANEZ, L. TVE Brasil cenas de uma história. Rio de Janeiro: Acerp, 2007. MULTIRIO. Relatório de gestão 1993-1996. Rio de Janeiro: MultiRio, 1996. MULTIRIO. Relatório de produtividade - 2014. Rio de Janeiro: MultiRio, 2014.

NOVO MANUAL DA REDAÇÃO. São Paulo: Folha de São Paulo, 1992.

OAKES, E. H. Encyclopedia of World Scientists. New York: Facts on File, 2007.

OROZCO GÓMES, G. Audiências. Mediações e televisão pública: a desconstrução múltipla da televidência na era da vassalagem mediática. In: RINCÓN, O. (Org.) Televisão pública: do consumidor ao cidadão. São Paulo: Friedrich-Ebert-Stiftung, 2002.

OROZCO GÓMES, G. Televisión, audiencias y educación. Colômbia: Norma, 2001.

OROZCO GÓMES, G. Uma pedagogia para os meios de comunicação. Comunicação \& Educação, São Paulo, n.12, p. 77-88, maio/ago. 1998. PANDIT, N. R., The creation of Theory: a recent application of the Grounded Theory Method. The Qualitative Report, v. 2, n. 4, p.45-67, 1996. Disponível em: http://www.nova.edu/ssss/QR/QR2-4/pandit.html. Acesso em: 02 dez. 2014.

PORCHAT, M. E. Manual de radiojornalismo Jovem Pan. São Paulo: Ática, 2004.

PORTARIA INTERMINISTERIAL No 651, de 15 de abril de 1999. Disponível em:http://www.mc.gov.br/index.php?option=com_mtree\&task=att_download\&lin k_id=127\&cf_id=24. Acesso em 02 dez. 2014.

RINCÓN, O. (Org.). Televisão pública: do consumidor ao cidadão. São Paulo: Friedrich-Ebert-Stiftung, 2002.

RIO DE JANEIRO. Lei no 2029 de 18 de outubro de 1993. Decreta a criação da Empresa Municipal de Multimeios Ltda. - MULTIRIO. Câmara Municipal do Rio de Janeiro, RJ. Disponível em: http://cm-rio-dejaneiro.jusbrasil.com.br/legislacao/273214/lei-2029-93. Acesso em: 22 maio 2013.

SECRETARIA NACIONAL DE JUVENTUDE - SNJ. Agenda Juventude Brasil - Pesquisa Nacional sobre Perfil e Opinião dos Jovens Brasileiros 2013. Brasília: SNJ, Nov. 2013. Disponível em: bit.ly/WIE4fe. Acesso em: 31 out. 2014.

SELDES, G. O lugar da televisão na arte e na cultura. In: NETO, T. N. (Org.). Educational television the next ten years. Rio de Janeiro: Bloch, 1970.

SILVA JUNIOR, L. F. Haverá TV Pública no Brasil? Análise da TV Educativa brasileira para compreensão de rumos da TV Pública. São Paulo, 2013. 117 p. Dissertação, especialização em Comunicação, Universidade Anhembi Morumbi, São Paulo, 2013.

SÍTIO DO PICA-PAU AMARELO. TV Globo. Memória Globo. Disponível em: http://memoriaglobo.globo.com/programas/entretenimento/infantojuvenis/sitiodo-picapau-amarelo. Acesso em: 15 jan. 2015. Programa de TV.

THE GROUNDED THEORY INSTITUTE. Coordenação de Barney Glaser. Site oficial de Barney Glaser e Classic Grounded Theory. Disponível em: http://www.groundedtheory.com/. Acesso em: 01 dez. 2014.

TORNERO, J. M. P., VILCHES, L. Libro Blanco sobre la Televisión Educativa y Cultural em Iberoamérica. Barcelona: Gedisa, 2010.

TRAQUINA, N. Teorias do jornalismo: porque as notícias são como são. Florianópolis : Insular, 2012. 
TRAVANCAS, I.; FARIAS, P. (Orgs.). Antropologia e comunicação. Rio de Janeiro: Garamond, 2003.

UNESCO. El siglo de La television. Disponível em http://unesdoc.unesco.org/images/0007/000701/070196so.pdf\#70196. Acesso em: 24 nov. 2014.

UNESCO. Indicadores de qualidade nas emissoras públicas. Disponível em http://unesdoc.unesco.org/images/0021/002166/216616por.pdf. Acesso em: 24 nov. 2014.

UNESCO. Guidebook of broadcast and newspaper indicators. Disponível em http://www.uis.unesco.org/2013-en.pdf. Acesso em: 24 nov. 2014.

VIGOTSKI, L. S. A construção do pensamento e da linguagem. São Paulo: Martins Fontes, 2009.

WATTS, H. On camera: o curso de produção de filme e vídeo da BBC. São Paulo: Summus, 1990.

WOLF, M. Teorias da comunicação. Lisboa: Presença, 2003.

YEBRA, M. F. Televisón y telespectadores: um conflito permanente. Comunicar, Revista Científica de Educomunicación, n. 25, p. 125-130, 2005. 


\section{8. \\ Anexo: Grades Curriculares faculdades de Educação e Comunicação}

Castelo Branco. Grade curricular disponível em: http://www.castelobranco.br/site/index.php?option=com_jake\&jrun=\%2Fgraduac ao-distancia\%2Fexibir\%2F32\&japp=ucb. Acesso em: 24 nov. 2014.

Centro Universitário Augusto Motta, UNISUAM. Grade curricular disponível em http://www.unisuam.edu.br/index.php/disciplinas-jornalismo. Acessado em: 30 jan. 2014.

Escola Superior de Propaganda e Marketing, ESPM. Grade curricular disponível em http://www2.espm.br/cursos/graduacao/rio/jornalismo-0. Acessado em: 30 jan. 2014.

Faculdade CCAA. Grade curricular disponível em http://www.faculdadeccaa.com.br/cursos/graduacao/comunicacaosocial/jornalismo. Acesso em: 30 jan. 2014.

Faculdade Pinheiro Guimarães. Grade curricular disponível em: http://www.faculdadepinheiroguimaraes.edu.br/1semestre.html. Acesso em: 30 jan. 2014.

Faculdades Integradas Hélio Alonso - Facha. Grade curricular disponível em http://www.facha.edu.br/dmdocuments/matriz_curricular_jor.pdf. Acesso em: 30 jan. 2014.

Gama e Sousa. Grade curricular disponível em: http://www.gamaesouza.edu.br/site/graduacao_detalhe.asp?codigo_conteudo=5. Acesso em: 24 nov. 2014.

Ibmec. Grade curricular disponível em http://www.ibmec.br/site/DetalheCursos/rio-de-janeiro/barra-da-tijuca/graduacao/Escola-de-Comunicacao-eMarketing/Jornalismo. Acessado em 30/01/2014.

PUC-Rio. Grade curricular disponível em: http://www.pucrio.br/ensinopesq/ccg/comunicacao_jornalismo.html. Acesso em: 30 jan. 2014.

PUC-Rio. Grade curricular disponível em: http://www.pucrio.br/ensinopesq/ccg/pedagogia.html. Acesso em: 24 nov. 2014.

SENAC. Grade curricular disponível em: http://www.ead.senac.br/graduacao/licenciatura-em-pedagogia/.Acesso em: 24 nov. 2014.

Sousa Marques: Grade curricular disponível em: http://www.souzamarques.br/pedagogia. Acesso em: 24 nov. 2014. 
UFRJ. Grade curricular disponível em: http://www.educacao.ufrj.br/fluxogramaped.pdf. Acesso em: 24 nov. 2014.

Unicarioca. Grade curricular disponível em: http://www.unicarioca.edu.br/cursos/graduacao/pedagogia. Acesso em: 24 nov. 2014.

Universidade Castelo Branco. Grade curricular disponível em http://www.castelobranco.br/site/index.php?option=com_jake\&jrun=\%2Fgraduac ao\%2Fexibir\%2F22\&japp=ucb. Acesso em 30/01/2014.

Universidade do Estado do Rio de Janeiro. UERJ. Grade curricular disponível em: http://cederj.edu.br/cederj/cursos/pedagogia/. Acesso em: 24 nov. 2014.

Universidade do Rio de Janeiro. Unirio. Grade curricular disponível em: http://cederj.edu.br/cederj/cursos/pedagogia/. Acesso em: 24 nov. 2014.

Universidade Estácio de Sá. Unesa. Grade curricular disponível em: http://portal.estacio.br/unidades/universidade-estacio-desa/cursos/graduacao/bacharelado-e-licenciatura/pedagogia.aspx. Acesso em: 24 nov. 2014.

Universidade Estadual do Rio de Janeiro. Grade curricular disponível em http://www.fcs.uerj.br/1_graduacao/grade_curricular/grade_materias_jr.htm, Acesso em: 30 jan. 2014.

Universidade Federal do Rio de Janeiro. Grade curricular disponível em https://www.siga.ufrj.br/sira/temas/zire/frameConsultas.jsp?mainPage=/repositori o-curriculo/A63C55CF-92A4-FB5F-0077-7497D1660798.html. Acesso em: 24 nov. 2014.

Universidade Veiga de Almeida. Grade curricular disponível em: http://www.uva.br/cursos/ead/pedagogia. Acesso em: 24 nov. 2014. 